\author{
Universidade de São Paulo \\ Faculdade de Filosofia, Letras e Ciências Humanas \\ Departamento de Ciência Política
}

Diogo Augusto Ferrari

Descentralização Fiscal e Repartição da Receita Pública: o FPE na Constituinte de 1988

São Paulo

2013 
Diogo Augusto Ferrari

\title{
Descentralização Fiscal e Repartição da Receita Pública: o FPE na Constituinte de 1988
}

\author{
Dissertação apresentada ao programa de \\ pós-graduação do Departamento de Ciência Política \\ da Universidade de São Paulo, \\ como requisito para a obtenção do título \\ de Mestre em Ciência Política
}

Orientadora: Marta Teresa da Silva Arretche

São Paulo 
Folha de aprovação

Diogo Augusto Ferrari

Descentralização Fiscal e Repartição da Receita Pública: o FPE na Constituinte de 1988

Aprovado em:

Dissertação apresentada ao programa de pós-graduação do Departamento de Ciência Política da Universidade de São Paulo, como requisito para a obtenção do título de Mestre em Ciência Política.

Banca Examinadora:

Prof. Dr.

Instituição:

Assinatura:

Prof. Dr.

Instituição:

Assinatura:

Prof. Dr.

Instituição:

Assinatura:

Prof. Dr.

Instituição:

Assinatura: 
Para Minha Família, a grande e a pequena. 


\section{Agradecimentos}

Antes mesmo de entrar no curso de graduação em Ciências Sociais na Universidade de São Paulo, munido apenas de intuições sobre essas ciências e com pouquíssimo conhecimento sistematizado, havia definido para mim mesmo o objetivo de contribuir para a produção de conhecimento nessa área científica, tanto quanto meu esforço e vocação permitissem. Na raiz desse objetivo estava um interesse, diria quase patológico, pelas relações de determinação que se estabelecem entre indivíduo e sociedade, mas também pelo método (científico) que fundamenta a produção de conhecimento sobre essas relações. Aos poucos, no decurso de minha graduação, esse interesse difuso foi ganhando forma e conteúdo na medida em que recebia treinamento substantivo e metodológico no programa de graduação da Universidade de São Paulo.

Gostaria de mencionar, já que professores têm o ingrato destino de desconhecer a exata dimensão da influência que exercem, quatro cursos foram de fundamental importância na minha trajetória. O primeiro foi um curso de graduação ministrado pelo Prof. Dr. Rogério Arantes sobre Política Comparada. Nesse curso tive contato com algumas questões metodológicas e substantivas que despertaram em definitivo meu interesse por produzir conhecimento em Ciência Política. O segundo foi um curso ministrado pelo Prof. Dr. José Jeremias de Oliveira, chamado Metodologia e Epistemologia das Ciências Sociais. Esse curso exerceu (e ainda exerce) grande influência no meu entendimento sobre a fundamentação do conhecimento em Ciências Sociais. O terceiro foi um curso ministrado pela Profa. Dra. Marta Arretche sobre Políticas Sociais. Esse curso despertou meu interesse por essa área de pesquisa, me levou a procurar a Profa. Marta Arretche para pedir que fosse minha orientadora no Mestrado e resultou em um esboço de tema de pesquisa que acabou se transformando nessa dissertação. Por fim, exerceu grande influência na minha formação um curso ministrado pelo Prof. Ernesto Calvo, professor visitante da Universidade de Maryland, que ofereceu o curso Multilevel Analyses in Comparative Politics. Esse curso me introduziu nas questões avançadas relacionadas com Métodos e Técnicas de pesquisa, reavivando em definitivo meu interesse, ora dormente, pela Matemática, Estatística e Programação Estatística e suas aplicações no estudo de

fenômenos Políticos e Sociais. Hoje, são áreas às quais me dedico com bastante entusiasmo.

Agradeço ao Prof. Fernando Limongi por todo apoio e pelas lições. Durante o mestrado tive o privilégio de conviver com o Prof. Limongi como estagiário no programa de estágio supervisionado do programa de pós-graduação, como aluno e como auxiliar de pesquisa. Aprendi muito nesse tempo todo. Agradeço-o também por ter aceitado compor tanto minha banca de qualificação quanto de defesa desta dissertação. 
Gostaria de registrar um agradecimento especial ao Prof. José Álvaro Moisés, com quem trabalhei por diversos anos em pesquisas de iniciação científica e em outros projetos acadêmicos. Durante a convivência, tive a oportunidade acumular bastante experiência e aprendizado que foram e são muito importantes na minha trajetória.

À Profa. Marta Arretche, que me orientou no mestrado e com quem tive o privilégio de conviver nesses anos, agradeço pela paciência, pela disposição para discutir, para ensinar e por todo o apoio que recebi. O que não está ponderado em nenhum lugar é o que a convivência ensina de forma capilar. Aprendi muito com sua seriedade e comprometimento, com sua postura profissional e com sua franqueza.

Agradeço aos membros do nosso grupo de estudos do qual participo, composto por Patrick Silva, Paulo Loyola, Ricardo Ceneviva, Edney Dias, Rogério Schlegel, Elize Massard, Murilo Junqueira, Fernando Marques e Ivo Yoshida, por todas as estimulantes discussões.

Agradeço aos Professores George Avelino, Sergio Prado, Lorena G. Barberia e Rogério Arantes que aceitaram participar da minha banca de defesa de mestrado. Agradeço também ao Prof. Ciro Biderman que fez uma leitura bastante cuidadosa e fez comentários importantíssimos na minha qualificação. Tais comentários foram definidores para o desenvolvimento final desse trabalho.

Agradeço aos funcionários do Departamento de Ciência Política, Vasne, Leo, Rai, Ana e Marcia, que sempre prestaram um grande auxílio nesse tempo todo.

Certamente não teria chegado até aqui sem o suporte emocional e financeiro que sempre recebi dos meus pais. Eles foram responsáveis por ensinamentos e lições de vida que escola nenhuma seria capaz de ensinar.

Por fim, agradeço à minha esposa Irene, que foi e é a grande companheira nessa jornada. Aguentou meu mau-humor nos momentos mais difíceis, protestou nos fins de semana roubados pelo trabalho e sempre me contagiou com sua alegria. Nossa casa é onde está nosso coração. Sempre estive em casa ao seu lado.

Este trabalho foi financiado pela CNPq, a quem também deixo meu agradecimento. 


\section{Resumo}

Esta dissertação explica o desenho fiscal aprovado pela Assembleia Nacional Constituinte de 1988. No desenho adotado, aumentaram as transferências constitucionais e intensificou-se a redistribuição interregional de receita pública. Apesar do aumento na redistribuição horizontal da receita pública, nenhum estado perdeu com as modificações. Três fatores explicam esse resultado. Primeiro, a distribuição regional da renda fez com que se formasse uma coalizão dos estados das regiões pobres, Norte, Nordeste e CentroOeste, com baixa capacidade de arrecadação própria que demandavam aumento da receita via transferências redistributivas. Segundo, a regra da decisão por maioria garantia vantagem para essas regiões na medida em que justas elas detinham a maioria das cadeiras na maioria das instâncias decisórias da constituinte. O terceiro fator que explica o desenho adotado é o duplo vínculo dos parlamentares. Ao mesmo tempo em que defendiam o interesse de seus estados, seu distrito eleitoral, eram membros de partidos nacionais. Se impusessem perdas aos estados das regiões ricas, companheiros partidários poderiam ser punidos eleitoralmente, fazendo com que o próprio partido perdesse cadeiras. Por isso a solução ótima foi adotar um sistema que intensificava a redistribuição horizontal, mas que não impunha perda de receita em relação ao status quo para nenhum estado. Fosse a maioria composta de constituintes de regiões ricas, ou fossem os parlamentares membros de partidos estritamente estaduais, o resultado certamente seria outro. 


\begin{abstract}
This dissertation explains the fiscal design that was approved by the Constitutional Convention of 1988. Although the new Constitution augmented the interregional redistribution of public revenue between states, no state lost revenue when we compare the new situation and the status quo. Three factors explain this outcome. First, poor states formed a coalition. These states had low capacity to raise its budget through selfgenerated revenue. So, they demanded more regional redistribution through constitutional transfers. Second, this coalition was favored by the majoritarian rule of the Constitutional Convention once they were majority in almost every arena. Finally, the last element that explains the outcome is that the representatives in Constitutional Convention were all members of national parties. At the same time the representatives defended the interest of their state, they defended the interest of their party. If they had chosen a different fiscal design and this design had caused loss of revenue to the states of the minority, this decision could have caused electoral losses for their own party in the states that were losing revenue. For this reason, they augmented the regional redistribution, but they did not impose loss of revenue for other states. If either the rich states were majority or the representatives were all members of local parties, the outcome would be quite different.
\end{abstract}




\section{Sumário}

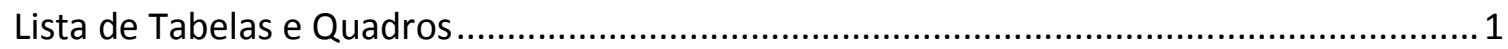

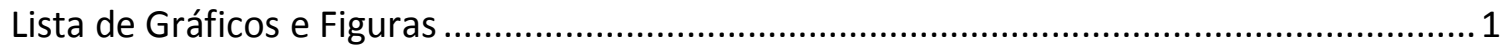

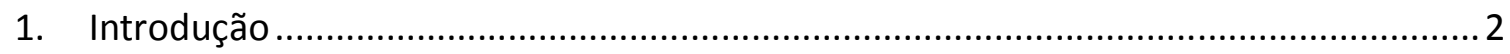

2. Escolhas de desenhos fiscais em estados federativos ....................................................

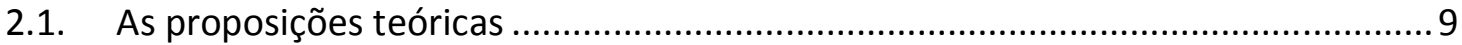

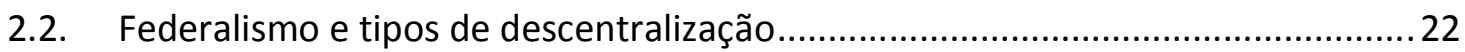

2. A escolha do desenho fiscal na Constituinte de 1988 .................................................. 29

2.1. Arenas decisórias e Propostas de reforma fiscal ....................................................29

2.2. As duas coalizões regionais na Subcomissão de Tributos, Participação e Distribuição de Receita

2.3. As barganhas legislativas na Comissão do Sistema Tributário, Orçamento e

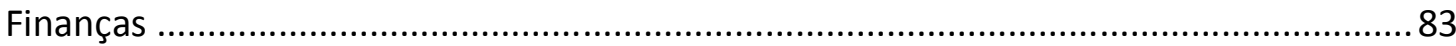

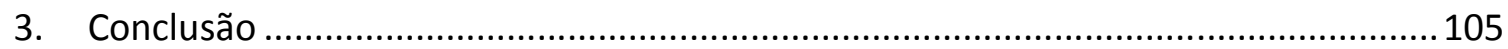

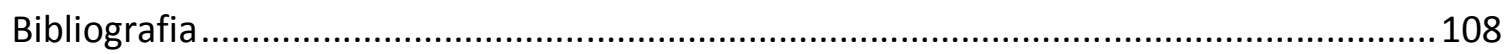

A. Apêndice

A.1. Construção das variáveis para teste da hipótese do modelo do eleitor mediano 114

A.2. Dotação e Critérios de rateio do FPE entre 1966 e 2012 ...................................116

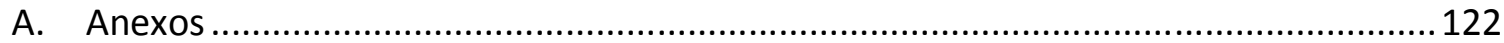

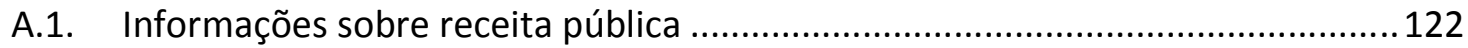




\section{Lista de Tabelas e Quadros}

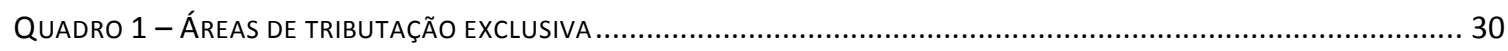

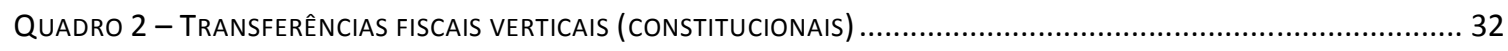

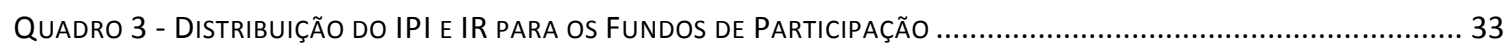

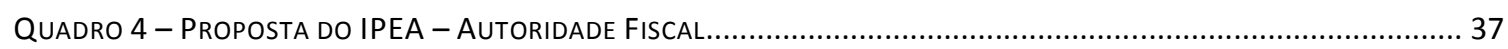

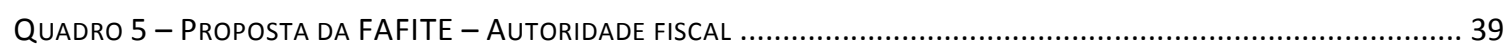

QUADRO 6 - PROPOSTA DOS SECRETÁRIOS DA FAZENDA DOS ESTADOS DA REGIÃO NO, NE E CO - AUTORIDADE FISCAL 41

QUADRO 7 - PROPOSTAS NA STPDR SOBRE ÁREA DE TRIBUTAÇÃO EXCLUSIVA................................................... 44

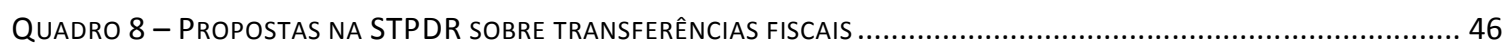

TABELA 9 - RELAÇÃO ENTRE RECEITA PÚBLICA RESULTANTE DAS PROPOSTAS SOBRE RECEITA FISCAL NO STATUS QUO....... 49

QUADRO 10 - ÁREA DE TRIBUTAÇÃO EXCLUSIVA NAS INSTÂNCIAS DECISÓRIAS DA CONSTITUINTE DE 1988 ....................80

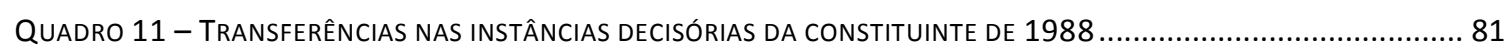

TABELA 12 - DISTRIBUIÇÃO REGIONAL E PARTIDÁRIA NA STPDR …............................................................ 92

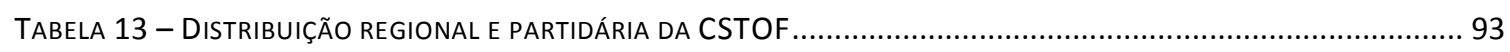

TABELA 14 - DISTRIBUIÇÃO REGIONAL E PARTIDÁRIA NA COMISSÃO DE SISTEMATIZAÇÃO …..................................... 93

TABELA 15 - DISTRIBUIÇÃO REGIONAL E PARTIDÁRIA DO PLENÁRIO DA ANC DE 1988 ...............................................94

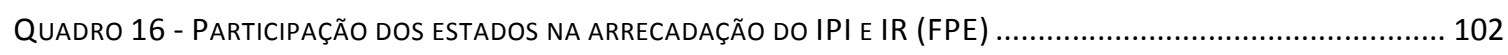

\section{Lista de Gráficos e Figuras}

FIGURA 1 - DistRIBUIÇÃO DE PREFERÊNCIAS POR REDISTRIBUIÇÃO NA CONSTITUINTE DE 1988 SEGUNDO O MODELO DO

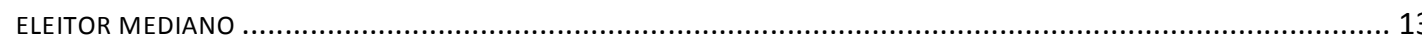

FIGURA 2 - IMPACTO NA RECEITA ESTADUAL ESTIMADA DAS PROPOSTAS APRESENTADAS NA STPDR EM RELAÇÃO AO

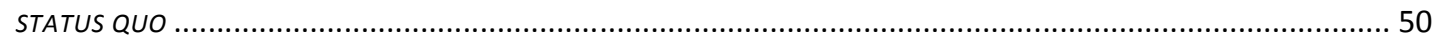

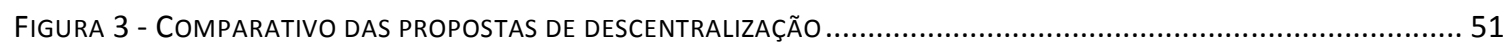

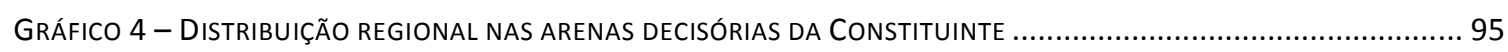

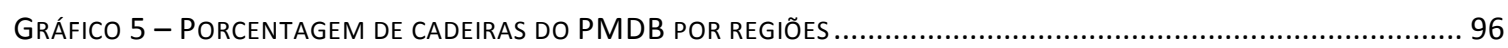

GRÁFICO 6 - PORCENTAGEM DE CADEIRAS DO PMDB E PFL (SOMADOS) POR REGIÕES ...........................................9. 97 


\section{Introdução}

No dia 24 de fevereiro de 2010, o Supremo Tribunal Federal (STF) decretou a inconstitucionalidade, sem pronúncia de nulidade, da Lei Complementar no 62 de 1989, que define os critérios de rateio entre os estados e as macrorregiões do Fundo de Participação dos Estados e do Distrito Federal (FPE). O FPE é um fundo Federal composto por uma porcentagem do Imposto sobre Produtos Industrializados (IPI) e do Imposto de Renda (IR), cujo percentual global em vigor fora definido na Constituição de 1988. Desde 1989, é a Lei no 62 que define a porcentagem do FPE destinada a cada um dos estados. 0 STF decretou que o Congresso Nacional teria até o final de 2012 para rever os critérios de rateio do FPE da Lei $n$ o 62 de 1989 e regular a parcela que cada estado deveria passar então a receber. O que motivou essa decisão do STF foram quatro Ações Diretas de Inconstitucionalidade (ADI's) movidas por governadores de alguns estados das regiões Sul e Centro-Oeste ${ }^{1}$.

Em situação igualmente associada à disputas de cunho federativo, o governo federal anunciou oficialmente, no segundo semestre de 2007, a descoberta de campos de petróleo em uma área chamada de "Pré-sal". O montante potencial de recursos públicos que poderiam ser aferidos da exploração desses campos fez emergir tanto questões sobre o emprego social dessas rendas quanto questões federativas sobre sua redistribuição entre os níveis de governo.

A necessidade prática dessas decisões políticas evoca questões de ordem teórica sobre as respostas que a Ciência Política tem a oferecer sobre os resultados de processos decisórios quando escolhas de desenhos que implicam realocação de recursos fiscais entre as subunidades estão em jogo.

\footnotetext{
${ }^{1}$ São elas: ADI no 875/1993 de autoria dos governadores dos estados da Região Sul (Santa Catarina (SC), Paraná (PR) e do Rio Grande do Sul (RS)); ADI 1987/1999 de autoria do governador do Mato Grosso (MT) e do governador do estado de Goiás (GO); ADI no 2727/2002 e ADI 3243/2004 de autoria de governadores do estado do Mato Grosso.
} 
Podemos localizar o problema da repartição de receita fiscal entre níveis de governo dentro da Ciência Política em geral, e da Política Comparada em específico, como um tópico dos estudos sobre o federalismo fiscal. Nessa literatura, o problema das decisões relacionadas com a repartição de receita aparece vinculado aos estudos sobre descentralização e centralização fiscal. Há dois grupos principais de trabalhos que tratam desse tema ${ }^{2}$ : aqueles que consideram os efeitos de determinada estrutura fiscal sobre fenômenos políticos e econômicos e aqueles que abordam o desenho fiscal como variável dependente. Essas duas abordagens estão ligadas por alguns estudos que consideram os efeitos esperados que poderiam resultar da adoção de desenhos fiscais alternativos como um dos fatores explicativos para a própria escolha desses desenhos.

No primeiro grupo estão trabalhos seminais de autores ligados à chamada teoria da escolha pública e à economia política do bem-estar. Algumas abordagens destacam os efeitos benéficos que podem advir da adoção de estruturas de governo com autoridade política e fiscal descentralizada. Os argumentos apresentados por essa literatura são que estados descentralizados seriam capazes de atingir resultados superiores aos de estados centralizados, seja porque a descentralização permite que preferências dos cidadãos sejam reveladas; que problemas de assimetria de informação sejam contornados; que bens públicos sejam ofertados com maior eficiência; que melhore a fiscalização e diminua a corrupção porque estados descentralizados estão mais próximos dos cidadãos; ou ainda porque estados descentralizados permitem que sejam preservados com mais eficiência o mercado e os cidadãos contra intervenções governamentais e expropriações de direitos pelo governo (Brennan \& Buchanan, 1980; Buchanan, 1996; Hayek, 1939; Inman \& Rubinfeld, 1997; Qian \& Weingast, 2011; Tiebout, 1956; Weingast, 1995, 2007, 2009). Um pressuposto central desses argumentos é a mobilidade de pessoas e capitais entre as subunidades (Tiebout, 1956). Essa mobilidade permite que preferências dos cidadãos

\footnotetext{
${ }^{2}$ É importante mencionar que essas duas abordagens tratam do problema da escolha de estruturas fiscais e de repartição de receitas, definidas constitucionalmente ou por legislação específica. Estudos sobre transferências intergovernamentais discricionárias também são abrangentes na literatura, mas abrangem outro tipo de problema teórico. Para esses casos, ver Gibson, Calvo, \& Falleti (2003) e Rodden (2009).
} 
sejam reveladas e, aceitando que os governantes locais queriam satisfazer a preferência de seu eleitorado, eles podem alocar os recursos de forma mais eficiente.

Algumas das consequências benéficas da descentralização foram questionadas por diversos autores (Paterson \& Rom, 1990; Peterson, 1995; Prud'homme, 1995). Havendo mobilidade de pessoas e capitais, a descentralização pode resultar em uma competição entre as subunidades para ofertar a menor quantidade de políticas de bem-estar social de modo a não atrair a população pobre de outras jurisdições (Peterson, 1995).

Tanto no caso desses últimos autores como no caso dos primeiros, ao fim e ao cabo a desigualdade é o preço a ser pago pela descentralização. Tanto a desigualdade na oferta de políticas e na capacidade de gasto, quanto a desigualdade na distribuição de renda, em especial sua distribuição interregional, são resultados não somente de fatores econômicos, mas também da descentralização da autoridade associada ao estado federativo. A descentralização aparece, portanto, como uma variável causal exógena em relação a essas desigualdades.

Alguns autores têm apontado para a relação endógena entre desigualdade e descentralização. A desigualdade não seria um efeito imediato da descentralização. Ao contrário, desigualdades diversas, como as étnicas, linguísticas, culturais e econômicas entre a população expõem um governo excessivamente centralizado aos custos gerados por pressões advindas desses diferentes grupos. Argumenta Rodden que "a natureza da descentralização ou do federalismo [...] podem ser codeterminadas por outras variáveis como a geografia econômica, a heterogeneidade da população, a migração, a distribuição de renda e a demanda por democracia e redistribuição" (2005, p.24). A descentralização aparece, então, como um resultado da desigualdade na medida em que ela permitiria que diferentes demandas originárias de heterogeneidade territorial fossem atendidas, aliviando assim o governo central, no limite, de riscos de secessão (Oates, 1972; Panizza, 1999; Rodden, 2005).

Alguns autores têm concentrado sua análise na relação endógena entre distribuição regional de renda e descentralização fiscal. Segundo o argumento principal 
desses estudos, a distribuição de renda importa justamente porque o desenho fiscal poderá produzir efeitos redistributivos (Alesina \& Perotti, 1998; Bolton \& Roland, 1997; Sambanis \& Milanovic, 2009; Wibbels, 2005). Por esse motivo é que, segundo essa abordagem, em estados federativos, "distributional concerns play a fundamental role in shaping the organization of fiscal structures" (Beramendi, 2007, p.6).

Porém, por um lado, a relação entre o efeito redistributivo esperado e os determinantes das escolhas fiscais ainda carece de sofisticação conceitual e empírica para apreender a complexidade - ou multidimensionalidade - das decisões relacionadas com a autoridade fiscal e a distribuição de receita entre os níveis de governo (Rodden, 2005). Por outro, as principais proposições causais ainda carecem de acumulação de estudos empíricos que testem com cuidado sua validade, particularmente através de estudos de caso nos quais o processo decisório é estudados em sua complexidade. Desenvolvimento conceitual e acumulação de estudos de caso são, portanto, dois caminhos abertos e profícuos nos estudos sobre descentralização fiscal.

Sob a iminência das decisões políticas relacionadas com repartição de receita fiscal entre estados no Brasil destacadas no início dessa introdução, e sob a luz do debate teórico brevemente apresentado, esse estudo examina as decisões relacionadas com a adoção do desenho fiscal na Constituinte de 1988.

A Constituinte de 1988 é um evento privilegiado para o estudo de decisões sobre a estrutura fiscal por dois motivos. Primeiro, porque foi um momento em que toda estrutura do sistema fiscal estava em debate, de modo que as partes e o todo poderiam ser reestruturados de uma vez. Segundo, porque a Constituinte de 1988 guarda características parecidas com a configuração institucional atual. Entre as principais características estão a eleição dos representantes, cujo distrito eleitoral são os estados ${ }^{3}$, a decisão concentrada institucionalmente no centro, sem necessidade de adesão formal de legislativos subnacionais, a existência dos partidos e de lideranças partidárias atuando

\footnotetext{
${ }^{3}$ Como se sabe, a Assembleia Nacional Constituinte foi composta por deputados e senadores a partir da legislatura - um Congresso Constituinte, portanto - que estava em atividade, e que fora eleita no processo eleitoral imediatamente anterior, em novembro de 1986.
} 
dentro do contexto decisório, partidos nacionais ou suprarregionais, a estrutura federativa e o legislativo federal como principal arena decisória.

O último ponto do parágrafo acima deve ser considerado com cuidado, porque ele se refere a uma importante delimitação do tipo de problema empírico a que esse trabalho se dedica. Na década de noventa e nos anos que se seguiram à redemocratização de 1985-1988, diversos analistas diagnosticaram que o sistema político brasileiro definido pela Constituição de 1988 seria ingovernável. Esse sistema seria incapaz de gerar a coordenação necessária entre os diversos atores políticos para a realização de políticas nacionais. As razões apontadas eram que o sistema seria demasiadamente fragmentado, com um multipartidarismo exacerbado, um sistema eleitoral de lista aberta, um federalismo forte e com subunidades dotadas de poder de veto (Abrucio \& Samuels, 1997; Abrucio, 1998; Ames, 1995; Lamounier, 1992, 1994; Mainwarning, 1997; Stepan, 1999). Estudos empíricos mais recentes têm contestado essas interpretações. O governo conta com uma alta taxa de aprovação de sua agenda (Figueiredo \& Limongi, 1999, 2000). Além disso, do ponto de vista federativo, a União tem aprovado projetos que envolvem imposição de perdas para as subunidades, e o comportamento das bancadas estaduais está estruturado na grande maioria dos casos em bases partidárias (idem; Arretche, 2007, 2009, 2010). Porém, a análise a que se dedica este estudo se aplica a decisões que envolvem conflito horizontal, entre estados, e não um conflito vertical, na qual o governo central se opõe aos governos subnacionais.

Esta dissertação tem dois objetivos. O primeiro é teórico. Ao se discutir as teorias sobre escolhas de desenhos fiscais em governos multiníveis, aplicá-las ao caso empírico em questão, e apresentar uma hipótese alternativa que explica as decisões para o caso investigado, espera-se contribuir para o desenvolvimento de teorias explicativas dos determinantes de desenhos fiscais em estados federativos. Como Rodden aponta, estudos sobre federalismo fiscal têm apresentado baixíssimo ajuste entre teoria, conceitos e complexidade do fenômeno empírica e localmente observado. Isso ocorre devido à necessidade de utilizar indicadores comparados em estudos de grande $N$ que muitas vezes são inadequados para servir de proxy para os conceitos e relações 
teoricamente formulados. O resultado é a baixa capacidade explicativa das teorias, que parecem incapaz de explicar os fenômenos realmente observados, mesmo no agregado. Assim, diz que "alguns aspectos institucionais, como os incentivos derivados de vários tipos de transferências, organização legislativa e as relações políticas entre os líderes políticos centrais e locais, devem ser analisados primeiramente por meio de estudos de caso, apoiados em hipóteses comparativas, para depois poder avançar nas análises quantitativas que comparam um grande número de países" (Rodden, 2005, p. 24).

O segundo objetivo desse trabalho é oferecer hipóteses explicativas adequadas para o caso brasileiro quando estão em jogo decisões a cargo do legislativo federal sobre a redistribuição de receitas públicas entre os estados. As decisões sobre a reformulação do critério de rateio do FPE e a divisão do "Pré-Sal", ainda em trâmite, estão entre esses casos.

$\mathrm{Na}$ análise empírica aqui empreendida, mostra-se que, durante a constituinte, a divisão das receitas públicas ocorreu de tal modo que, mesmo intensificando a redistribuição interregional em relação ao status quo (aumento da redistribuição horizontal, portanto), nenhum estado perdeu receita. $\mathrm{O}$ aumento na redistribuição interregional e interestadual (horizontal) de receita pública foi acompanhado de um aumento no montante total destinado aos governos subnacionais. Os maiores ganhadores detinham maiorias parlamentares, mas não impuseram perdas à minoria. Essa maioria parlamentar, formada por uma coalizão regional de estados do Norte, Nordeste e Centro-Oeste, defendia inicialmente uma posição que descentralizava receita pública via transferências constitucionais e as destinava quase exclusivamente para suas regiões, impondo assim perdas para os demais estados. Essa posição foi flexibilizada ao longo da constituinte. Essa maioria aceitou negociar para mitigar as perdas de receita dos demais estados. Quais foram os incentivos para essa negociação? Porque aceitaram diminuir seus ganhos e não impor perdas aos estados que detinham minoria dos votos na Assembleia? O argumento principal deste trabalho é que o duplo vínculo dos representantes, vinculados tanto aos partidos nacionais quanto aos estados onde são eleitos, fez com que a solução ótima fosse não impor perdas à minoria. Enquanto 
oriundos de determinado estado, buscaram trazer mais receita pública para seu distrito eleitoral. Enquanto membros de determinado partido, buscaram não punir eleitoralmente companheiros partidários e, portanto, o próprio partido, caso fossem os companheiros acusados de permitir a redução de receita pública de seus estados.

Tal explicação peticiona por generalização na medida em que algumas condições sejam observadas. O sistema político, ou o contexto político-institucional, no qual a análise pode buscar aplicação é aquele de um sistema multipartidário, com distritos eleitorais para eleição do legislativo federal que correspondem às subunidades constituintes, parlamentares que sejam membros de partidos nacionais (ou ao menos suprarregionais) e presença de desigualdade interregional de renda (portanto, desigual capacidade de geração de receita pública). Além disso, a decisão em questão deve ser feita por congressistas pela regra da maioria, sem necessidade de ratificação formal de instituições políticas das subunidades. Garantidas tais condições mínimas, entende-se que esse estudo de caso pode trazer uma hipótese útil para se avaliar outros casos e contribuir para análises comparadas.

O trabalho está organizado da seguinte forma. Primeiro discute-se as teorias explicativas sobre decisões fiscais em estados federativos, bem como explicações que tratam especificamente do caso empírico estudado aqui. Apresenta-se em detalhes a hipótese alternativa. Antes da análise empírica propriamente, discute-se ainda algumas distinções conceituais importantes para que haja uma correta correspondência entre fenômeno empírico observado e os conceitos teóricos mobilizados. Em seguida, apresentam-se as mudanças no desenho fiscal introduzidas na constituinte do ponto de vista das dimensões da descentralização fiscal que estavam em jogo e as negociações que levaram a essas mudanças. Por fim, as considerações finais são apresentadas. 


\section{Escolhas de desenhos fiscais em estados federativos}

\section{1. $\quad$ As proposições teóricas}

Como discutido na introdução, as decisões sobre o desenho fiscal em estados federativos são abordadas predominantemente pela literatura especializada do ponto de vista da descentralização, seja discutindo seus efeitos, seja discutindo suas causas. As direções recentes desses estudos têm combinado essas duas abordagens considerando os efeitos esperados de desenhos fiscais como uma das variáveis independentes por trás das motivações que levam à adoção de determinados desenhos.

Nessa linha, Beramendi $(2007,2012)$ adota a teoria do eleitor mediano para explicar a formação de preferências dos representantes por desenhos fiscais, conforme argumento desenvolvido por Alesina \& Perotti (1998) e Bolton \& Roland (1997). O argumento assume que em democracias o nível de redistribuição interregional, ou horizontal, é um fenômeno que ocorre como resultado da preferência do eleitor mediano. Atores políticos buscam apoio eleitoral dos eleitores de seus distritos eleitorais. Como as decisões em questão envolvem redistribuição, a preferência relevante no modelo é a preferência do eleitor mediano em relação aos seus níveis de taxação e redistribuição desejados. Se o eleitor mediano de uma região achar que estaria em melhor situação em um governo cuja taxação é centralizada, pois assim teria maior (ou menor) taxação e redistribuição, essa será também a posição defendida pelos representantes locais. Por isso, determinar as preferências desse eleitor é central para entender às preferências fiscais dos representantes das regiões.

Para definir a preferência do eleitor mediano regional e, portanto, do seu representante, Beramendi (2007) desenvolve um modelo analítico que formaliza o efeito de duas variáveis causais principais. Em primeiro lugar, importa a distribuição intra e interregional de renda no status quo. Quanto mais baixa for a renda do eleitor mediano 
em relação à renda média, maiores níveis de redistribuição ele demandará de seu governo.

Dois exemplos simplificados ajudam a ilustrar o argumento. Considerando um Cenário $A$ hipotético totalmente descentralizado, no qual há somente duas regiões de renda média e população iguais. Haverá maior pressão por redistribuição na região cujo eleitor mediano possuir menor renda. Digamos que na Região $1\left(R_{1}\right)$ a renda do eleitor mediano, denotada por $\tilde{R}_{1}$, seja menor que a média na sua região. Digamos que na Região 2 a renda do eleitor mediano, denotada por $\widetilde{R}_{2}$, seja maior que a média na sua região. No caso, o eleitor mediano de menor renda sairia perdendo com a centralização. Isso porque a renda do eleitor mediano nacional estaria em algum ponto entre a renda dos eleitores medianos das duas regiões, ao passo que a renda média seria igual. Tudo mais constante, para o eleitor mediano regional que tinha menor renda, a centralização representa menor redistribuição do que ele gostaria. A figura abaixo ilustra o argumento, sendo que $\widetilde{N}$ representa a renda do eleitor mediano nacional, $\bar{N}$ a renda média nacional e $f(x)$ representam as distribuições nacional e nas regiões, conforme subscrito.

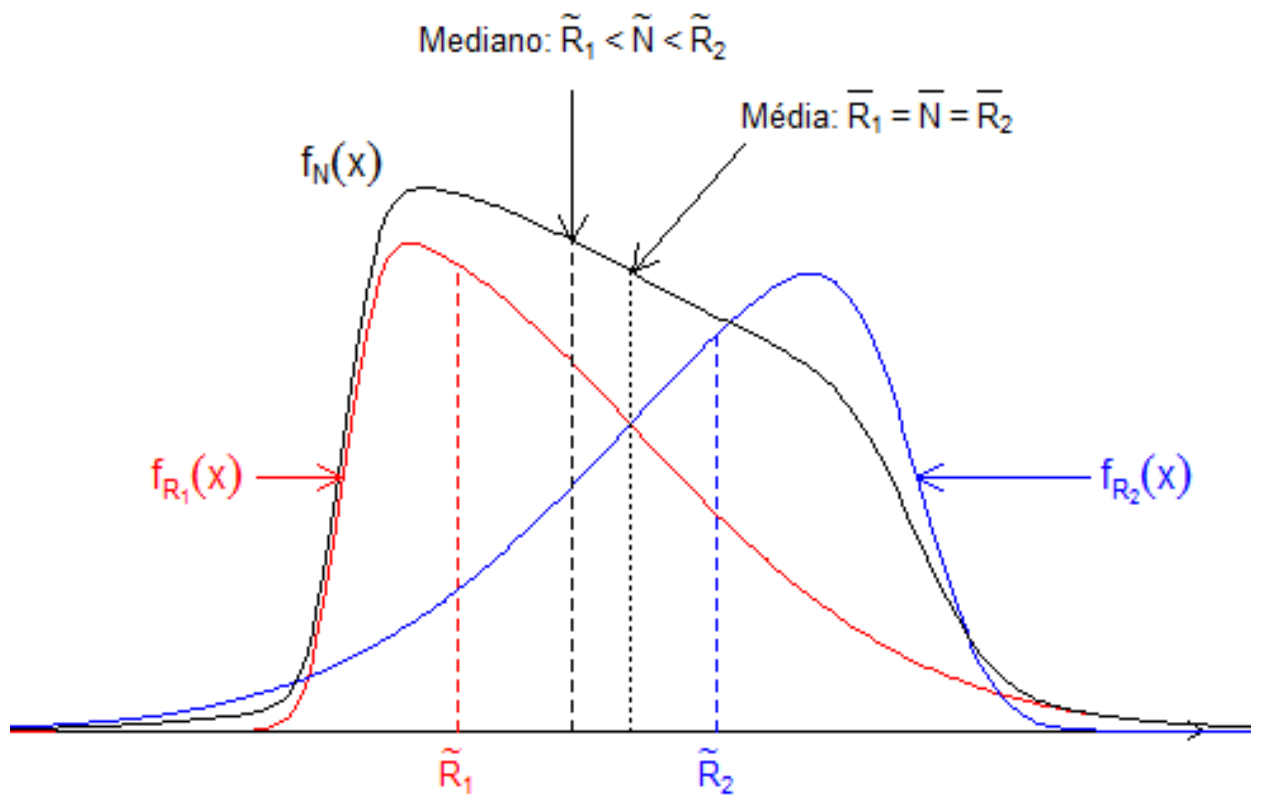


Outra situação ocorre em um Cenário $B$ também descentralizado no qual os eleitores medianos de duas regiões de igual população possuem rendas iguais. Digamos que a Região 1 tenha renda média maior que a Região 2. Ou seja, a Região 1 é mais rica, embora o mediano das duas regiões tenham mesma renda. O eleitor mediano da região mais pobre estaria em melhor situação em caso de centralização porque em um cenário centralizado a renda média nacional seria maior do que a renda média em sua região. Portanto, poderia demandar redistribuição de um montante maior. Já o eleitor mediano da região mais rica estaria em pior situação.

Além da renda, Beramendi introduz um segundo elemento que diz ser fundamental na definição da preferência do eleitor mediano por redistribuição. Esse elemento é o risco de perda de emprego. Assume que o risco de perda de trabalho está diretamente associado com o grau de especialização econômica da região. Quanto maior a especialização da região, maiores riscos de perda de trabalho. Regiões que oferecem maiores riscos de perda de trabalho para o eleitor mediano sofrerão maiores pressões por taxação e redistribuição via políticas de seguridade (Estevez-Abe, Iversen, \& Soskice, 2001; Iversen \& Soskice, 2001). De resto, a comparação entre um cenário centralizado e descentralizado segue o mesmo raciocínio aplicado à renda.

Esses dois fatores, ou seja, a distribuição interpessoal e interregional da renda, bem como o risco da perda de emprego formam o que chama de estrutura territorial da desigualdade (territorial structure of inequality). Eles determinam a preferência do eleitor mediano por desenhos fiscais ou, igualmente, por níveis de redistribuição. O modelo que quantifica essas preferências do eleitor mediano é dado pela seguinte equação (para detalhes da derivação ver Beramendi (2007)):

$$
E\left[U_{d}^{m}(c)\right]-E\left(U_{c}^{m}\right)=\frac{1}{2}\left(y-y_{\mu}\right)+\frac{\beta w^{m}\left(2 \beta w^{m}-\lambda y-\theta\right)}{2(\lambda y+\theta)}-\frac{\beta w_{\mu}^{m}\left(2 \beta w^{m}-\lambda y-\theta\right)}{2\left(\lambda_{\mu} y_{\mu}+\theta_{\mu}\right)}
$$

,onde $\beta$ é a proporção da população empregada; $\lambda$ representa a proporção da população desempregada; $y$ representa o PIB per capita; $w$ representa a renda do eleitor 
mediano; $\theta=2\left(\beta\left(w^{m}\right)^{2}\left(1+\sigma_{z}^{2}\right)\right.$ e ; $\theta_{\mu}=2\left(\beta\left(w_{\mu}^{m}\right)^{2}\left(1+\sigma_{z \mu}^{2}\right)\right.$ são, respectivamente, os termos que capturam o risco de perda de renda do indivíduo no nível nacional e no nível regional, $\sigma$ é um indicador de diversificação da atividade econômica. O subscrito $\mu$ indica que a variável é medida no nível nacional, e a ausência indica que a variável é medida no nível regional.

A equação acima, portanto, nos fornece um modelo heurístico para investigar as preferências dos eleitores medianos regionais. Se o representante regional derivasse sua preferência exclusivamente desse modelo, este poderia nos fornecer um retrato das coalizões regionais esperadas nos momentos em que decisões sobre desenho fiscal fossem tomadas.

Segundo esse modelo, a distribuição de preferências por níveis de taxação e redistribuição na Constituinte de 1988 seria esta expressa na FIGURA 1 - DISTRIBUIÇÃO DE PREFERÊNCIAS POR REDISTRIBUIÇÃO NA CONSTITUINTE DE 1988 SEGUNDO O MODELO DO ELEITOR MEDIANO (detalhes dos dados e das variáveis estão no Apêndice). 
FIGURA 1 - DISTRIBUIÇÃO DE PREFERÊNCIAS POR REDISTRIBUIÇÃO NA CONSTITUINTE DE 1988 SEGUNDO O MODELO DO ELEITOR MEDIANO

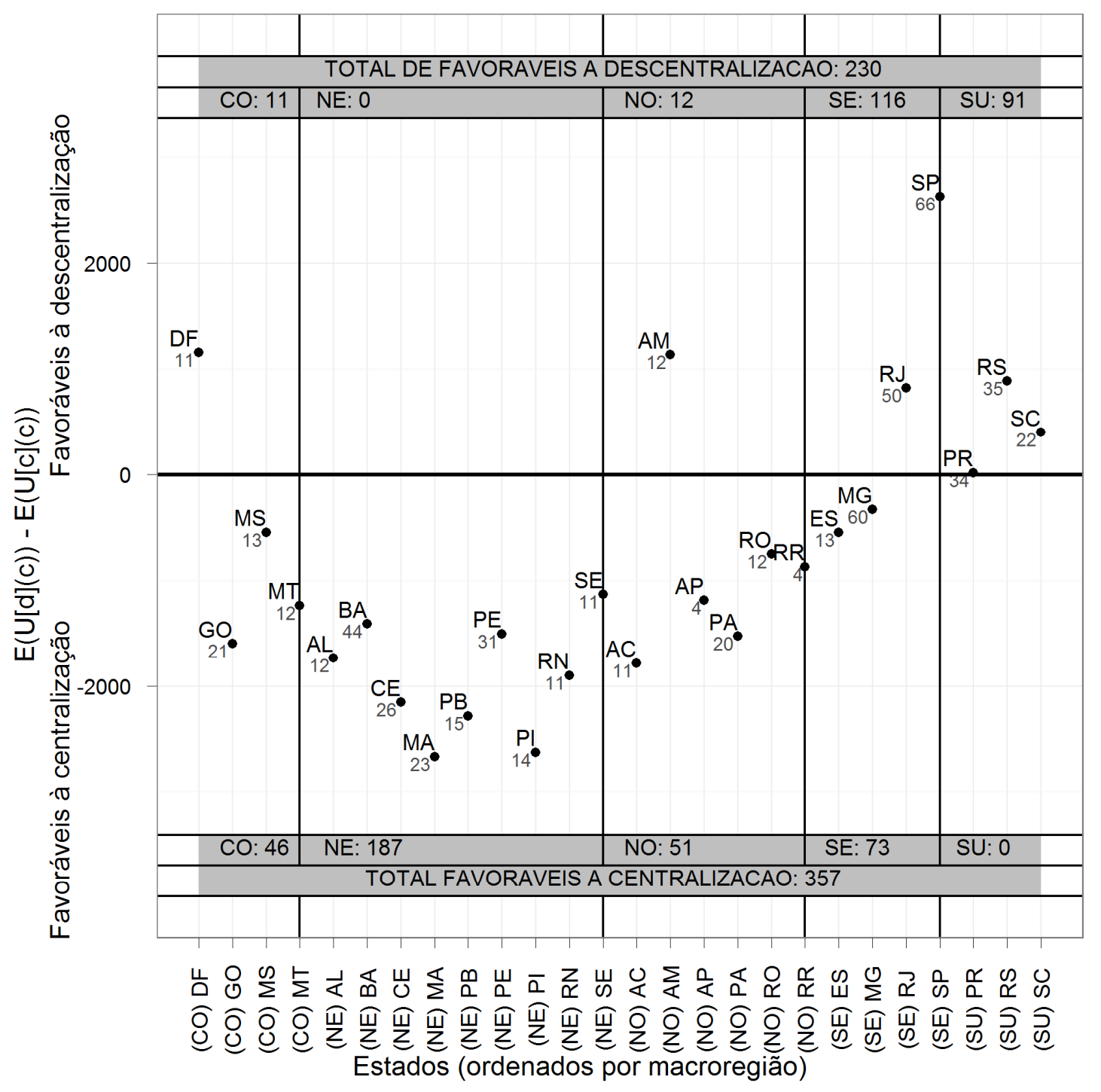

Porém, no modelo de Beramendi (2007) não há partidos nem política partidária. 0 representante regional é identificado somente pelo seu pertencimento à região de origem, e só importa a preferência do eleitor mediano regional. Porém, como ressalta Rodden (2005, p.21),

"as teorias de descentralização endógena, se bem que visam a iluminar tendências recentes, devem ir além das teorias do eleitor mediano nas quais a descentralização é conceitualmente equivalente à secessão. Talvez seja 
mais relevante perguntar por que os políticos escolhem tornar o Estado mais imbricado e complexo. Por exemplo, quais incentivos conduzem os políticos do governo central a abrir mão de ter responsabilidade independente sobre a provisão de certos bens públicos e compartilhar responsabilidades com os governos locais para o financiamento da provisão descentralizada por meio de transferências? [...]

Em suma, além de uns poucos estudos sobre a descentralização de despesas, trabalhos comparados sobre a descentralização endógena em matéria de impostos, política e de políticas são um território ainda sem exploração. O caminho mais promissor para uma próxima geração de pesquisas seria abordar uma gama mais ampla de variáveis de descentralização e complementar os modelos do eleitor mediano com pressupostos mais realistas sobre instituições e políticas."

Em seu livro de 2012, Pablo Beramendi adiciona um segundo fator que condiciona a preferência dos representantes. Esse novo modelo leva também em consideração o conflito intrapartidário que pode ocorrer devido à divergência entre as preferências das elites regionais e nacional do partido por desenhos fiscais.

Segundo o argumento, a elite partidária regional pode tentar propor uma mudança no status quo no sentido de descentralizar o sistema fiscal. Se a elite nacional é contra a descentralização, isso pode gerar conflito intrapartidário, que pode resultar por sua vez em custos eleitorais para o partido. Esses custos são, por exemplo, a perda de votos dos eleitores regionais, arriscando assim as chances eleitorais do partido. Um importante fator que pode determinar os resultados, portanto, é a importância da eleição regional para o partido nas regiões que demandam descentralização. Se a liderança partidária nacional entende que a eleição regional é muito importante, os custos de se opor a descentralização podem ser grandes. Tais custos aumentam a probabilidade dessa elite nacional aceitar a descentralização.

Uma vez que esse modelo considera somente o conflito intrapartidário entre elites regionais e nacionais do mesmo partido, ele omite-se no que diz respeito ao conflito entre 
elites regionais de um mesmo partido nacional. Em outras palavras, falta incluir o conflito intrapartidário horizontal. Pode ocorrer que a disputa por desenhos fiscais ocorra entre tipos de descentralização, e não apenas entre centralização e descentralização. Elites regionais podem concordar em descentralizar o sistema fiscal, e não encontrar resistência de elites que defendem o governo central. Entretanto, as elites regionais podem discordar quanto à forma que essa descentralização deve tomar. Foi justamente esse tipo de conflito horizontal que teve importante influência na definição do sistema fiscal brasileiro na Constituinte de 1988, e que se repete em grande medida nas decisões sobre a reforma dos critérios de rateio do FPE e sobre a distribuição dos recursos do Pré-Sal.

Além de não considerar essa dimensão da barganha, o modelo precisa ser adaptado para comportar a ocorrência de (1) múltiplos representantes regionais; (2) de multipartidarismo; (3) de incentivos para alianças interregionais; (4) de influência das regras que regulam o processo decisório.

Em um estudo de caso sobre as decisões relacionadas com a distribuição de cadeiras e a repartição de receita fiscal entre os estados na Constituinte de 1988, Leme (1992) aponta outros fatores como determinantes das escolhas do desenho fiscal. Para o autor, na Constituinte a questão federativa girou em torno, principalmente, da repartição de receita fiscal.

Ele diz que o comportamento das bancadas na Constituinte nesse tema seguiu uma lógica estadualista e regionalista. As barganhas para repartição da receita entre os estados envolveram duas dinâmicas. Primeiro as bancadas estaduais se uniram para garantir descentralização de recursos da União. Segundo, estados e regiões tiveram que negociar entre si como seria a repartição dessa receita. Leme (1992) aponta que os estados foram bem sucedidos em aumentar o montante global de transferências porque, além de poucos defensores dos interesses da União nas fases decisórias em que os acordos foram firmados (na Subcomissão de Tributos, Participação e Distribuição de Receita e na Comissão do Sistema Tributário, Orçamento e Finanças), representantes que defendiam o interesse da União cometeram o erro estratégico de entrar na negociação 
tardiamente, na Comissão de Sistematização, acreditando que esta seria a instância principal e na qual poderiam impor sua preferência. Porém, a essa altura, os acordos interregionais já estavam formados (idem, p.148).

A disputa entre os estados pela repartição da receita, por seu turno, teve dois resultados distintos. Por um lado, resultou em aumento do montante total das receitas destinadas às subunidades via transferências. Ou seja, manteve-se em parte a centralização da autoridade e da arrecadação e intensificou-se a repartição da receita. Por outro lado, a disputa dividiu os interesses dos estados e alguns impasses não puderam ser resolvidos na própria constituinte. Nesse caso, o impasse dizia respeito à repartição horizontal da receita fiscal.

Para Leme (1992), a disputa principal se deu entre os estados das regiões Norte, Nordeste e Centro-Oeste, que demandavam mais transferências, e as regiões Sul e Sudeste. Os estados do Sul, em especial Rio Grande do Sul, se sentiram prejudicados com os critérios de distribuição do Fundo de Repartição dos Estados (FPE) conforme foram decididos na Subcomissão de Tributos, Participação e Distribuição de Receita. Rio Grande do Sul demandava o Fundo de Ressarcimento para Estados Exportadores (FR), pois segundo arguia isso compensaria perdas devidas ao eventual rateio do FPE. A aceitação do FR pelas bancadas do Norte, Nordeste e Centro-Oeste serviu como moeda de troca na negociação por mais transferências do FPE, que foi aumentado então de 18,5\% para 21,5\%. Ainda no bojo dessa barganha, negociaram e aprovaram o "fortalecimento do poder tributário estadual, através da maior abrangência do ICMS e do poder residual dos estados" (idem, p.164). Porém, ao fim e ao cabo, não houve acordo na Comissão e nem na própria Constituinte sobre o critério de rateio do FPE. Esse critério foi postergado para legislação complementar (Leme, 1992, p.164).

Em suma, o autor diz que os estados da região Sul e Sudeste em geral apoiaram mais transferências em troca do apoio do Norte e Nordeste para aprovar regras que davam maior liberdade aos estados para fixação da aliquota (do ICMS), entregavam-Ihes poder residual e aumentavam o FR (Leme, 1992, p.157). Diz o autor que "os 
representantes dos estados do Norte, Nordeste e Centro-Oeste concederam (sic), no que diz respeito ao fortalecimento da autonomia tributária estadual, em troca de aumento nas transferências federais. Promoveu-se assim uma acomodação de interesses regionais, cuja condição foi ter a União como perdedora"(Leme, 1992, p.150). No decorrer do processo decisório, pouca mudança ocorreu após esse acordo. A principal foi que a União pode retirar o poder residual dos estados, mas os percentuais das transferências não foram diminuídos ou alterados.

Porém, não fica claro nesta explicação a motivação dos atores para a negociação. As regiões Norte, Nordeste e Centro-Oeste eram, juntas, maioria na Constituinte. Portanto, não precisavam negociar ou fazer concessões às regiões mais ricas do país. Leme (1992) diz que ocorreu um processo de log-rolling entre as regiões, que trocaram transferências por descentralização. Mas o log-rolling pressupõe que haja mútua dependência. Não há nada na explicação ou nas evidências que aponte para essa dependência das regiões do Norte, Nordeste e Centro-Oeste a ponto de ser vantajoso trocar apoio. Sendo maioria, poderiam aprovar regras conforme lhes fosse vantajoso, e não precisavam recuar ou ceder às regiões Sul e Sudeste, concedendo descentralização de autoridade fiscal em troca de transferências. Como será demonstrado na seção empírica, não foi a aceitação do FR, do poder residual para os estados e da descentralização do ICM(S), medidas que beneficiavam as regiões ricas, que serviu de moeda de troca para mais transferências para o FPE, que beneficiavam as regiões pobres. $\mathrm{O}$ que determinou aumento nos percentuais globais do FPE, fundo que beneficiaria majoritariamente os estados mais pobres, foi um conflito relacionado, ele mesmo, com uma cláusula que definia a repartição horizontal desse fundo.

David Samuels (2003), por outro lado, argumenta que os constituintes estavam preocupados com suas próprias carreiras políticas. Carreirist motivations, ligadas às eleições em nível local, determinaram a posição dos representantes a favor de aumentar a autonomia dos entes subnacionais; garantir transferências automáticas livres da manipulação do centro e das negociações políticas com atores políticos daquela esfera; descentralizar poucos encargos; e assegurar a autonomia de gasto dos recursos. Além 
disso, Samuels (2003) afirma, como outros, que a preferência por desenhos centralizados versus descentralizados, tanto de representantes no Congresso quanto de políticos das subunidades, estava ligada à receita pública dos entes subnacionais (Nogueira, 1995; Oliveira, 1995a, 1995b; Samuels, 2003). A forma para obter maiores receitas dependia da capacidade de arrecadação das subunidades.

"Like their representatives in Congress, whether governors and mayors would favor fiscal transfers [and therefore centralization] over increasing states' and municipalities' own taxation authority depends on whether the state or municipality can generate tax revenue" (Samuels, 2003, p.168)

Porém, políticos de carreira, com carreiras ligadas aos governos locais, em diversos países, têm motivações desse tipo, mas nem por isso as federações são iguais. Embora essa motivação possa estar presente, ela não explica as variações encontradas nos desenhos fiscais das federações. Para Samuels, muitos constituintes almejavam carreiras nos executivos locais e, portanto, viam a descentralização como forma de dar poder a si mesmos quando eleitos para postos em governos locais. Mas, novamente, isso não explica porque a maioria teria incentivos para negociar com a minoria, como de fato ocorreu, resultando assim no desenho fiscal adotado pela Constituição de 1988.

Souza (1997), por sua vez, argumenta que o desenho fiscal é resultado de uma troca de mais transferências para estados das regiões mais pobres por mais cadeiras na Câmara para São Paulo (Souza, 1997, p.82). Além disso, a autora aponta que os representantes votavam junto com seus partidos ou regiões a depender do tema em questão. Na questão do desenho fiscal e da repartição de receita, "parties' delegates behaved more according to their individual commitments or to their regional representation than to their parties' program." (idem). No que diz respeito à descentralização para os municípios, a autora apresenta uma explicação semelhante à de Samuels (2003). Segundo ela, havia uma ambição da maioria dos constituintes por se elegerem para posições executivas municipais (Souza, 1997, p.83). Ela aponta que um presidente fraco, governadores fortes, interesse de prefeitos, de constituintes 
individualistas que almejavam executivos locais, bem como fortalecer seus laços paroquialistas, explicam a descentralização dos recursos (Souza, 1997, p.84).

Por fim, vale ressaltar que alguns autores argumentam que a descentralização fiscal foi uma reação à centralização experimentada durante o regime militar (Oliveira, 1995c; Souza, 1997). O argumento principal é a coincidência entre democratização e descentralização. Porém, a variação de diversas dimensões do desenho fiscal parece não coincidir com as variações de regime (Arretche, 2005). A descentralização que ocorreu na Constituinte não foi irrestrita. Ela tomou uma forma específica, com alguns aspectos descentralizados e outros mantidos sob o controle da União. Uma reação pura à centralização a fim de aumentar a autoridade e dispersar o poder não explica o desenho específico adotado, como a seção empírica pretende demonstrar.

Arretche (2005, p.18) argumenta que a composição da assembleia e a interação estratégica dos atores dadas as regras decisórias explicam as decisões sobre o desenho fiscal federativo tomadas pela Constituinte de 1988. Porém, Arretche (2005) concentra-se no debate sobre a repartição vertical da autoridade fiscal e suas dimensões relacionadas, bem como no teste da hipótese de que mudança de regime está associada irrestritamente à descentralização. No que diz respeito à Assembleia Nacional Constituinte (ANC) de 1988, o artigo parte do argumento de Leme (1992) e toma como dadas as coalizões dos estados mais pobres - regiões Norte e Nordeste - contra os mais ricos, como de modo geral ocorreu. Não chega a explorar, no entanto, a hipótese desse autor sobre o que teria levado as maiorias a negociar com as minorias e a lhes fazer concessões.

Do ponto de vista teórico, os fatores explicativos para adoção de desenhos fiscais em federações discutidos até aqui podem ser resumidos como segue.

No modelo de Beramendi (2007), as preferências dos representantes regionais são determinadas pela preferência do eleitor mediano por níveis de taxação e redistribuição. Em uma extensão desse modelo, Beramendi (2012) aponta ainda que o impacto eleitoral de um conflito de preferências por desenhos fiscais entre a elite partidária local e nacional influencia as probabilidades de mudanças do status quo em direção à 
descentralização ou à centralização. Aceitando o argumento, espera-se com isso que a distribuição interregional de renda informe sobre preferências e, portanto, sobre possíveis coalizões regionais. Porém, falta considerar que as elites regionais talvez tenham preferências divergentes quanto ao tipo de descentralização fiscal a ser adotado. Ou seja, o conflito horizontal, entre elites locais, deve ser considerado. Além disso, a regra decisória desempenha um papel central, porque preferências não são transformadas imediatamente em decisões. Faz toda diferença se o desenho fiscal pode ser alterado por maioria legislativa ou somente por unanimidade.

Já na explicação de Leme (1992) como na de Samuels (2003) e Souza (2007), a ênfase é dada na preferência dos representantes por aumentar a receita pública das subunidades e garantir a livre alocação dos recursos. Esses três estudos argumentam que houve barganha entres estados de regiões ricas e estados de regiões pobres. Para Leme (1992), regiões pobres ofertaram apoio às regiões ricas para que estas aprovassem descentralização da taxação. As regiões ricas apoiaram em troca o aumento de transferência redistributivas via fundos de participação. Para Souza (2007), essas regiões trocaram transferências por cadeiras no legislativo federal. Nenhum dos autores aponta qual era o incentivo para essa troca de apoio, uma vez que as regiões pobres eram majoritárias e as decisões eram tomadas sob regra da maioria. Para que uma troca se realize, é preciso mútuo interesse. A maioria não teria porque ceder às negociações para que a decisão final se aproximasse de sua preferência.

Essas hipóteses são peças do quebra-cabeça, mas sozinhas não explicam adequadamente a decisão em questão, pois deixam de lado aspectos importantes que definiram o resultado. Um aspecto que teve papel central na definição do montante da receita descentralizada via transferências constitucionais foi o conflito por redistribuição horizontal das receitas públicas. Esse aspecto, em certa medida negligenciado na literatura, combinado com os outros destacados na sequência, desempenhou papel importante nas fases em que os acordos regionais na definição do desenho fiscal estavam sendo selados. 
A hipótese desta dissertação aceita parta das explicações descritas até aqui, mas avança no sentido de melhor explicar as causas do desenho fiscal adotado pela Constituinte de 1988. Seu argumento central pode ser dividido em dois aspectos. O primeiro diz respeito à motivação dos representantes regionais. Argumenta-se que na definição do desenho fiscal, a distribuição de renda das regiões determinou as preferências dos representantes dos estados, que se organizaram regionalmente e formaram duas coalizões com preferências distintas, dividindo Norte e Nordeste, de um lado, e Sul e Sudeste, de outro. Por isso, o modelo de Beramendi (2007) é útil para explicar a formação de coalizões regionais na escolha de desenhos fiscais. Porém, durante o processo decisório, a coalizão das regiões mais pobres organizada a favor da redistribuição interregional de renda converteu-se em uma coalizão que buscava estritamente a redistribuição interregional da receita pública. Misturadas no começo, a segunda dominou a barganha em um segundo momento, principalmente devido à assessoria prestada pelos Secretários da Fazenda dos estados, as constantes consultas pelos constituintes junto a esses secretários, além das simulações sobre os resultados das mudanças no orçamento das subunidades apresentadas por eles e por especialistas. 0 que definiu os interesses dos representantes estaduais a partir daí foram as implicações das mudanças na estrutura fiscal e na redistribuição de receita pública sobre o orçamento das subunidades em relação ao status quo, bem como a incerteza orçamentária introduzida pela modificação. Tais são os fatores principais que determinaram as preferências dos representantes.

Preferências apenas não explicam decisões. Assim, o segundo momento da explicação é que, dadas essas preocupações orçamentárias, as regras decisórias de decisão por maioria, a distribuição de atores nas arenas decisórias e, esse é o fator que faltava para dar sentido às barganhas, o duplo vínculo dos representantes, ligados partidariamente por um lado, mas eleitos nos estados por outro, se constituíram em incentivos suficientes para a barganha na definição do capítulo tributário. Foi isso que levou o conflito horizontal a ser resolvido de modo consensual, sem imposição de perdas para nenhum estado. As regiões pobres, uma vez que eram maioria, não barganharam o 
apoio das regiões ricas, trocando cadeiras por transferências, ou transferências por descentralização da autoridade tributária. O que ocorreu foi que esse duplo vínculo gerou uma solução ótima, cujo resultado foi não impor perdas de receita a nenhum estado. Se os representantes impusessem perdas para certos estados, companheiros de partido e, portanto, seu próprio partido, poderiam ser punidos eleitoralmente.

Vale destacar que no processo decisório que se desenrolou sob as regras da constituinte, a coalizão do Norte, Nordeste e Centro-Oeste, de um lado, e do Sul e Sudeste, de outro, tomou a forma regional e não apenas estadual devido a três fatores. Primeiro, porque historicamente essas regiões eram identificadas e entendidas como entidades que compartilhavam características socioeconômicas. Agrupam-se ali, de fato, os estados de menor renda per capita. Segundo, a legislação anterior reforçava a ficção das macrorregiões, definidas territorialmente, inclusive via legislação tributária. Uma regra criada a partir de 1979 dava tratamento diferenciado às regiões do Norte e Nordeste com percentuais exclusivos de transferências do Fundo de Participação dos Estados (FPE). Mas essas duas regiões não formavam maioria na constituinte. Por isso, o parceiro mais barato, e suficiente para formar uma maioria parlamentar na Constituinte era o Centro-Oeste, incluído então como beneficiário privilegiado das transferências constitucionais.

Antes de prosseguir, é importante ressaltar algumas diferenciações conceituais. Essa diferenciação irá pavimentar conceitualmente o caminho da análise empírica que se seguirá.

\subsection{Federalismo e tipos de descentralização}

Federalismo não é a mesma coisa que descentralização, e nem descentralização é uma coisa só. Ademais, estes não são conceitos triviais do ponto de vista teórico, apesar de seu uso indiscriminado o fazer parecer. Além da confusão existente na literatura entre esses dois conceitos, a forma de medir cada um não tem encontrado menos problemas. Delimitar melhor esses conceitos e levar tais definições a sério significa ampliar a capacidade de apreensão do fenômeno empírico a que eles se referem. Indo na direção 
inversa, criar melhores indicadores empíricos significa testar melhor as relações postuladas teoricamente. Nos dois casos, o resultado é melhorar a qualidade das teorias. Por isso, essa subseção define com mais precisão os conceitos que serão tratados empiricamente.

O conceito de federalismo tem importância acima de tudo histórica na Ciência Política. Remete aos estudos sobre o contrato fundador de estados nacionais através da junção de subunidades independentes e soberanas, cujo caso empírico paradigmático são os Estados Unidos. Implica, fundamentalmente, a existência de ao menos dois níveis distintos de governo. O conceito de federalismo possui significados diferentes a depender do autor que o utiliza. Para alguns autores, federalismo remete às "regras do jogo" que definem como os níveis de governo irão interagir para tomar decisões políticas, entre elas a alocação de autoridade entre os níveis de governo (Cremer, 2013; Lijphart, 1999; Riker, 1975; Rodden, 2005; Stepan, 1999). O conceito, no entanto, é muito vago e seu tratamento empírico está longe de ser consensual.

O conceito de descentralização, por seu turno, está relacionado com a estrutura de distribuição de autoridade entre esses níveis de governo. Por isso pode-se falar em federações centralizadas ou descentralizadas. Essa é uma dimensão que diferencia federações entre si. O problema da centralização e descentralização da autoridade só tem sentido em contextos de governo multiníveis, ou seja, em federações.

Rodden (2005) aponta que descentralização refere-se à "transferência de autoridade dos governos centrais para governos locais" (idem, p.10). Porém, também o conceito de descentralização tem sido tratado na literatura de modo pouco cuidadoso. Rodden argumenta que "questões sobre desenho, conteúdo e forma da descentralização são tratadas superficialmente, não porque as teorias e as hipóteses relevantes sejam pouco diferenciadas, mas devido às dificuldades envolvidas na coleta de dados mais refinados" (Rodden, 2005, p.10). Na literatura comparada, essa dificuldade se reflete na confusão entre conceito teórico relevante e o indicador empírico de descentralização utilizado. Um indicador amplamente utilizado, por exemplo, é a proporção de gasto dos 
governos locais em relação ao total de gastos. Esse indicador é utilizado para medir descentralização do sistema político de uma forma geral. No entanto, tal indicador não é capaz de adequadamente captar a complexidade e as diversas dimensões envolvidas na repartição de autoridade entre níveis de governo.

Na tentativa de lançar luz nesse problema e fornecer ferramentas para contornálo, o autor ressalta a descentralização a partir de três dimensões distintas: a autoridade fiscal, a autoridade política e a autoridade sobre a gestão de políticas (Rodden, 2005).

A descentralização da autoridade política diz respeito à eleição de representantes para governos de níveis subnacionais. As medidas dessa dimensão da descentralização são complexas, apesar da aparência de simplicidade. Por exemplo, dois sistemas podem se diferenciar sobre o quanto os partidos são centralizados ou não, ou o quanto as autoridades locais têm influência no processo eleitoral próprio e do centro, e vice-versa.

A descentralização da autoridade sobre políticas diz respeito à capacidade do governo central de se sobrepor às decisões de políticas adotadas pelos governo subnacionais. Rodden (2005) chega a propor um índice sintético que indica a autoridade sobre políticas dos governos subnacionais. Porém, vale ressaltar que há diversas áreas de políticas e diversas combinações possíveis de centralização e descentralização em cada uma dessas áreas. Como mostra estudos de Henderson (2000), o fenômeno mais frequente, nas políticas consideradas - educação básica, infraestrutura e força policial local - é a autoridade compartilhada.

Os estudos comparados sobre descentralização fiscal, por seu turno, em especial os de grande $N$, têm se concentrado majoritariamente na relação entre receita total e despesa dos diferentes níveis de governo como indicador de descentralização. Os países são diferenciados, nesses casos, pelo tamanho do gasto a cargo das subunidades. Se esse gasto é grande em relação ao do centro ou ao gasto total, assume-se que a federação é descentralizada. Essa tem sido a medida de descentralização mais utilizada. 
Como já apontado, o uso desse indicador como proxy para descentralização fiscal é equivocado, em especial porque ele refere-se somente a um tipo de descentralização, precisamente a descentralização do executor do gasto. No entanto, o argumento causal das teorias sobre descentralização fiscal refere-se, em muitos trabalhos, à autoridade decisória sobre políticas fiscais. Ou seja, esse indicador é equivocadamente utilizado para inferir sobre descentralização decisória quando empiricamente se está medindo proporção de gasto. Isso se reproduz não apenas nos estudos de descentralização fiscal, mas também nos outros tipos de descentralização listados acima. Usa-se a proporção de gasto com saúde, por exemplo, para inferir sobre a descentralização das políticas de saúde, mesmo quando o argumento teórico fala da autoridade decisória sobre políticas de saúde.

Considerando a descentralização fiscal, Rodden (2005) aponta, em termos da relação entre indicador e teoria, que a proporção do montante gasto pelos governos locais em relação ao total diz pouco sobre autoridade de alocação do gasto. Um governo central pode transferir montantes significativos cujos gastos são executados pelos governos locais, mas também definir como esse dinheiro deve ser empregado. Um exemplo que ocorre no Brasil são os gastos com educação do Fundo de Manutenção e Desenvolvimento da Educação Básica (FUNDEB). Governos locais recebem transferências federais. Porém, 20\% desses recursos são retidos para aplicação via FUNDEB. O mesmo argumento vale para os recursos próprios, seja no gasto, seja na arrecadação. No último caso, o governo central pode manter o controle de alíquotas, ainda que o governo local recolha o imposto. Essa medida de descentralização, a descentralização do gasto, pode sempre superestimar a descentralização de fato da autoridade fiscal, ou mesmo não informar nada sobre ela. Apesar desses problemas, essa medida continua sendo frequentemente utilizada para se referir teoricamente à descentralização de autoridade.

Essa diferenciação analítica entre federalismo e descentralização, e entre tipos de descentralização, é fundamental, em primeiro lugar, para esclarecer o escopo de análise, mas principalmente para pavimentar o tratamento empírico das decisões sobre o desenho fiscal. Contudo, essa diferenciação deve avançar. Cada tipo de descentralização de 
autoridade destacada envolve estruturas complexas e muitas dimensões. Na Constituinte de 1988, todas as dimensões do desenho fiscal estavam em jogo. É preciso então refinar o conceito de descentralização fiscal para melhor apreender as dimensões envolvidas e entender suas relações e seus determinantes. Nesse sentido, Arretche (2005) diferenciou seis dimensões que envolveram as decisões sobre o desenho fiscal federativo ao longo da história brasileira. Essas dimensões estão classificadas aqui em outras duas.

Conforme aponta Arretche (2012), nas dimensões relacionadas com a descentralização fiscal, é importante diferenciar aquelas relacionadas com autoridade decisória (policy decision-making) e aquelas relacionadas com a competência na execução (policy-making). Como também já apontado, a grande maioria dos trabalhos discute teoricamente a primeira dimensão, mas empiricamente observa a segunda. Com algumas adaptações, as dimensões envolvidas com a descentralização fiscal destacadas por Arretche (2005) podem ser agrupadas da seguinte forma ${ }^{4}$ :

\section{Dimensão do Policy making}

1. Áreas de tributação própria: remete aos impostos cuja arrecadação é de competência do nível de governo em questão. Constitucionalmente, ou no Código Tributário, são os artigos que listam os impostos de competência de cada ente federado. Esses impostos compõe a receita tributária própria dos entes federados, de modo que não incluem as transferências recebidas. Temos a receita tributária própria líquida quando descontamos também as transferências enviadas.

2. Transferências fiscais: remete à repartição de receita arrecadada que ocorre via transferências. Podem ou não ser redistributivas, e podem ou não ser livres de vinculação, ou seja, de regulação sobre as regras de aplicação desse recurso pelo beneficiário.

\footnotetext{
${ }^{4}$ Omitiu-se a autonomia para obtenção de empréstimos, adotada no texto de Arretche (2005) porque essa dimensão, apesar de fundamental do ponto de vista da caracterização do desenho fiscal, tem pouca utilidade teórica para o escopo de análise deste trabalho.
} 


\section{Dimensão do Policy decision-making}

3. Autoridade para legislar sobre as áreas de tributação própria: é a autoridade para decidir sobre isenções e alíquotas dos próprios impostos. Um imposto pode ser de competência estadual, por exemplo, mas as alíquotas reguladas pelo centro. Nesse caso, o estado não teria autoridade, apesar de ter o imposto definido em sua área de tributação própria.

4. Autoridade residual: é a autoridade para instituir impostos ou regular o fisco quando a legislação do nível superior é omissa.

5. Vinculação de gastos de receita: remete à autoridade para alocar as receitas fiscais, sejam elas oriundas de tributação própria, sejam elas oriundas de transferências.

Além dessa classificação, é importante diferenciar duas outras dimensões relacionadas com o item dois da dimensão de policy-making. Além da alocação vertical de receita fiscal, há disputas pela alocação horizontal de receita, ou seja, pela redistribuição interregional via transferências. Essa última subdimensão das transferências fiscais gera um trade-off entre dimensões da descentralização. Isso porque a descentralização da receita via transferências redistributivas interregionais implica a centralização de certos impostos, ou seja, implica que aumente a área de tributação própria do nível superior para que ele possa, então, redistribuir a receita entre regiões. Conflitos por redistribuição interregional entre governos de mesmo nível ocorrem somente em torno de transferências e implicam centralização da arrecadação no nível, ao menos, imediatamente superior. É justamente esse problema que desempenhou um papel importante na definição do desenho fiscal no Brasil.

Por fim, cabe uma última diferenciação conceitual, com importantes implicações teóricas. Redistribuição de renda não é a mesma coisa que redistribuição de receita pública. Esses dois conceitos não podem ser confundidos. Segundo Beramendi (2007), o efeito esperado de determinado desenho fiscal na distribuição de renda é que determina a preferência do eleitor mediano. Por essa via, é um dos fatores que determina a 
preferência do representante regional. Segundo pretendo mostrar, a distribuição de renda e a distribuição de receita pública estão relacionadas na formação das coalizões na ANC. Porém, a escolha do desenho fiscal produz efeito imediato sobre a distribuição de receita pública em relação ao status quo. O impacto da redistribuição de receita pública sobre a distribuição de renda é um passo que depende de diversos outros fatores, como a capacidade do governo de investir ou atrair investimentos, do uso eficiente das verbas públicas, entre outros fatores. Assim, o que ocorreu no Brasil foi que a coalizão que se formou na ANC pode ser explicada em parte pela distribuição de renda, captada pelo modelo de Beramendi (2007). Parte da explicação para a formação da coalizão, como a inclusão do Centro-Oeste na coalizão dos estados pobres, liderada pelo Norte e Nordeste, se deveu às regras de maioria. Além disso, uma vez formadas as coalizões, no decorrer do processo decisório foram os efeitos esperados sobre a receita pública das subunidades em relação ao status quo que governaram as barganhas sobre o desenho fiscal. 


\section{A escolha do desenho fiscal na Constituinte de 1988}

Esta seção apresenta a estrutura decisória da Constituinte e demonstra a barganha que ocorreu para definição do sistema fiscal, em especial do sistema de partilha vertical e horizontal de receitas entre os níveis de governo. A primeira subseção apresenta brevemente as principais arenas decisórias da Constituinte e as principais propostas de sistema tributário que estavam sendo debatidas. A segunda subseção apresenta as composições política e regional dessas arenas decisórias bem como as barganhas que ali ocorreram.

\subsection{Arenas decisórias e Propostas de reforma fiscal}

A constituinte de 1988 funcionou de modo descentralizado. Ela se organizava em oito Comissões, cada uma responsável por um tema. Cada Comissão era subdividida em três subcomissões, também organizadas por tema. As subcomissões elaboravam, votavam e enviavam o anteprojeto aprovado para a Comissão Temática respectiva. Cada Comissão Temática então juntava os três anteprojetos temáticos aprovados nas respectivas Subcomissões, apresentava seu anteprojeto com base nesses trabalhos, avaliava e votava o anteprojeto compilado. Cada Comissão Temática encaminhava então o anteprojeto aprovado para a Comissão de Sistematização. A Comissão de Sistematização repetia o processo, ou seja, era responsável por juntar as várias partes vindas das Comissões temáticas, e apresentar seu anteprojeto compilado, votá-lo, e então enviá-lo para ser votado na fase final, em plenário, em dois turnos.

O sistema fiscal que estava em funcionamento no início da constituinte de 1988 teve sua estrutura básica definida pela emenda №18 de 1965, seguida pela definição do Código Tributário Nacional (Lei no 5172/66), e pela Constituição de 1967, além de outras normas que se seguiram, modificando algumas partes da estrutura, sem modificar suas características fundamentais. Essa legislação estava marcada por uma orientação 
desenvolvimentista e definia um sistema fiscal centralizado, entregando à União a autoridade para regular praticamente todo o sistema fiscal. Concentrava nas mãos do governo central parte significativa da receita gerada. Considerando sua estrutura, o sistema também era pouco redistributivo do ponto de vista social e interregional. A única transferência que promovia redistribuição horizontal a nível estadual da receita fiscal era o FPE. E mesmo assim, a receita redistribuída era de apenas $10 \%$ do IPI e do IR (ver QUADRO 2 - TRANSFERÊNCIAS FISCAIS VERTICAIS (CONSTITUCIONAIS), valore muito abaixo dos atuais (QUAdRo 3 - DISTRIBUIÇÃo do IPI E IR PARA OS FUNDOS DE PARTICIPAÇÃo).

O QUADRO 1 - ÁREAS DE TRIBUTAÇÃO EXCLUSIVA, apresenta as mudanças ocorridas nas áreas de tributação exclusiva dos entes da federação na Constituição Federal de 1988 (CF88).

\section{QUADRO 1 - ÁREAS DE TRIBUTAÇÃO EXCLUSIVA}

\begin{tabular}{ll}
\hline \hline \multicolumn{1}{c}{ REFORMAS DE 1965-7 } & \multicolumn{1}{c}{ CONSTITUIÇÃO DE 1988 } \\
\hline \hline Imposto sobre Exportações (IE) & Imposto sobre Exportações (IE) \\
Imposto de Renda (IR) & Imposto de Renda (IR) \\
Imposto sobre Produtos Industrializados (IPI) & Imposto sobre Produtos Industrializados (IPI) \\
Imposto sobre Operações Financeiras (IOF) & Imposto sobre Operações Financeiras (IOF) \\
Imposto de Importação (II) & Imposto de Importação (II) \\
Imposto Territorial Rural (IPTR) & Imposto Territorial Rural (IPTR) \\
Imposto único sobre Uso Energia Elétrica (IUEE) & - \\
Imposto único sobre Produtos Minerais (IUM) & - \\
Imposto único sobre combustíveis e Lubrificantes & - \\
(IUCL) & - \\
Imposto sobre Serviços de Comunicação (ISC) & - \\
Taxa sobre Transporte (IT) & Imposto sobre Grandes fortunas (IGF) \\
\hline \hline
\end{tabular}

Continua... 
ESTADOS

Imposto sobre Circulação de Mercadorias (ICM)

Imposto sobre Propriedade de Veículos

Automotores (IPVA)

Imposto sobre Circulação de Mercadorias e Serviços

(ICMS)

Imposto sobre Propriedade de Veículos

Automotores (IPVA)

Imposto sobre Transmissão de bens imóveis (ITBI)

Imposto sobre Transmissão de bens imóveis (ITBI

causa-mortis)

Imposto sobre ganhos suplementares de capital

(IGC)

Imposto de Renda Retido na fonte (IRRF,

funcionários públicos)

adicional 5\% sobre IR

\begin{tabular}{ll}
\hline \hline & MUNICÍPIOS \\
\hline \hline Imposto sobre Serviços (ISS) & Imposto sobre Serviços de qualquer natureza (ISSQ) \\
Imposto sobre Propriedade Territorial Urbana (IPTU) & Imposto sobre Propriedade Territorial Urbana (IPTU) \\
& Imposto de Renda Retido na fonte (IRRF, \\
& funcionários públicos) \\
& Imposto sobre vendas a Varejo de combustíveis \\
& (IVVC) \\
Imposto sobre transmissão de imóveis intervivos & (ITBI intervivos) \\
\hline
\end{tabular}

Adaptado de Arretche, 2005; Brasil, CTN-1966, CF-1967, CF-1988, EC no18/65; Cossio, 2000; Junqueira,

2010.

Do ponto de vista da relação entre origem e destinação da receita pública, as transferências fiscais podem ser abordadas em sua dimensão meramente vertical, que remete à distribuição do bolo entre os diferentes níveis de governo,ou também em sua dimensão horizontal, que remete à redistribuição interregional de receita pública. 0 QUADRO 2 - TRANSFERÊNCIAS FISCAIS VERTICAIS (CONSTITUCIONAIS) apresenta as principais modificações introduzidas pela CF-88 na dimensão vertical das transferências em relação à Constituição anterior. 
QUADRO 2 - TRANSFERÊNCIAS FISCAIS VERTICAIS (CONSTITUCIONAIS)

\begin{tabular}{|c|c|}
\hline REFORMAS DE 1965-7 & CONSTITUIÇÃO DE 1988 \\
\hline \multicolumn{2}{|c|}{ DA UNIÃO } \\
\hline \multicolumn{2}{|c|}{ PARA ESTADOS } \\
\hline 10\% IPI e IR - Fundo de Participação dos Estados (FPE) & $21,5 \%$ IPI e IR - para FPE \\
\hline $50 \%$ IUEE & - \\
\hline $70 \%$ IUM & - \\
\hline $40 \%$ IUCL & - \\
\hline \multirow[t]{3}{*}{$50 \%$ IT } & - \\
\hline & 10\% IPI - Fundo Ressarcimento (FR) \\
\hline & $20 \%$ imposto criado pelo uso do poder residual \\
\hline \multicolumn{2}{|c|}{ DA UNIÃO } \\
\hline \multicolumn{2}{|c|}{ PARA MUNICÍPIOS } \\
\hline $10 \%$ IPI e IR para FPM & $22,5 \%$ IPI e IR para FPM \\
\hline $10 \%$ IUEE & - \\
\hline $10 \%$ IUM & - \\
\hline $10 \%$ IUCL & - \\
\hline $20 \%$ IT & - \\
\hline $100 \%$ ITR & $50 \%$ ITR \\
\hline \multicolumn{2}{|c|}{ DOS ESTADOS } \\
\hline \multicolumn{2}{|c|}{ PARA MUNICIIPIOS } \\
\hline $20 \%$ ICM & $25 \%$ do ICMS \\
\hline $50 \%$ IPVA & $50 \%$ do IPVA \\
\hline \multicolumn{2}{|l|}{$50 \%$ ITBI } \\
\hline & $25 \%$ do FR dos estados \\
\hline & $25 \% \mathrm{FE}$ \\
\hline
\end{tabular}

Adaptado de Arretche, 2005; Brasil, CTN-1966, CF-1967, CF-1988, EC no18/65; Cossio, 2000; Junqueira, 2010.

A maioria dos trabalhos sobre o federalismo fiscal no Brasil concentra-se na dimensão vertical da distribuição de receita e da autoridade fiscais (Arretche, 2005; Samuels, 2003; Souza, 1994). A dimensão horizontal das transferências, no caso considerando a redistribuição entre os estados, também foi alterada pela constituinte e pelas leis complementares que regularam os dispositivos constitucionais. As duas únicas transferências constitucionais cuja característica era a redistribuição interregional, em nível estadual e regional, antes da Constituinte de 1988, eram o Fundo Especial, destinado ao Nordeste e Norte, e o Fundo de Participação dos Estados (FPE). As vésperas da 
constituinte, este último contava também com uma parcela redistribuída exclusivamente para essas regiões. O decreto lei $1434 / 75$ reservava $20 \%$ do total do FPE para serem distribuídos exclusivamente para os estados do Norte e Nordeste. Os outros $80 \%$ eram redistribuídos por todos os estados, incluindo os do Norte e Nordeste (para detalhes das regras de rateio e sua evolução ao longo do tempo ver Apêndice "Dotação e Critérios de rateio do FPE entre 1966 e 2012"). O critério de distribuição das outras transferências para os estados apresentadas no QUADRO 2 - TRANSFERÊNCIAS FISCAIS VERTICAIS (CONSTITUCIONAIS) era a proporcionalidade em relação à arrecadação.

A Constituição de 1988 manteve o FPE e o Fundo Especial, ampliou seus montantes globais, e leis complementares intensificaram sua redistribuição horizontal. Para citar um exemplo desse último fato, a Lei Complementar no 62/89, aprovada logo após a constituinte, definia os critérios de rateio do FPE e destinava $85 \%$ da receita desse fundo exclusivamente para as regiões Norte, Nordeste e Centro-Oeste. (ver Apêndice "Dotação e Critérios de rateio do FPE entre 1966 e 2012"). Do ponto de vista dos montantes globais para os fundos de redistribuição, o QUADRO 3 - DISTRIBUIÇÃO DO IPI E IR PARA OS FUNDOS DE PARTICIPAÇÃo apresenta seus percentuais, incluindo ali o Fundo de Participação dos Municípios (FPM). O quadro apresenta as modificações desde 1965.

$\underline{\text { QUADRO } 3 \text { - DISTRIBUIÇÃO DO IPI E IR PARA OS FUNDOS DE PARTICIPAÇÃO }}$

\begin{tabular}{|c|c|c|c|c|c|}
\hline \multirow[t]{2}{*}{ Legislação } & \multirow{2}{*}{$\begin{array}{c}\text { Vigência da } \\
\text { regra }\end{array}$} & \multirow{2}{*}{$\begin{array}{c}\text { \%IPI e IR } \\
\text { para Fundo }\end{array}$} & \multicolumn{3}{|c|}{ Fundo } \\
\hline & & & FPE & FPM & FE \\
\hline EC no 18 de $1965^{(1)}$ & $1967-1968$ & $20 \%$ & $10 \%$ & $10 \%$ & ב--- \\
\hline$A C$ no 40 de $1968^{(2)}$ & $1969-1975$ & $12 \%$ & $5 \%$ & $5 \%$ & $2 \%$ \\
\hline$E C$ no 5 de 1975 & $1976-1980$ & $20 \%^{(3)}$ & $9 \%$ & $9 \%$ & $2 \%$ \\
\hline $\mathrm{EC}$ n 17 de 1980 & $1981-1983$ & $24 \%^{(3)}$ & $11 \%$ & $11 \%$ & $2 \%$ \\
\hline EC no 23 de 1983 & $1984-1985$ & $32 \%$ & $14 \%$ & $16 \%$ & $2 \%$ \\
\hline EC no 27 de 1985 & $1986-1988(\mathrm{CF})$ & $33 \%$ & $14 \%$ & $17 \%$ & $2 \%$ \\
\hline CF 1988 (art. 159) & $1989-2007$ & $47 \%^{(3)}$ & $21,5 \%$ & $22 \%$ & $3 \%$ \\
\hline EC no 55 de 2007 & $2008-2012$ & $48 \%$ & $21,5 \%$ & $23 \%$ & $3 \%$ \\
\hline
\end{tabular}

Fonte: www.camara.gov.br; www.planalto.gov.br; Souza (2011); Rocha (2010); Afonso (2010); MF-STN $(2005,2011)$. Elaborado pelo autor.

EC: emenda constitucional; AC: Ato Complementar; EC: emenda constitucional; LC: Lei Complementar; DL: Decreto-Lei.

(1) Criação do FPE e do FPM.

(2) Criação do FE, que foi regulamentado pelo decreto lei no 835 de 1969.

${ }^{(3)}$ Lei prevê aumento anual progressivo até atingir o valor final. 
Como o Quadro 3 - Distribuição do IPI e IR Para os Fundos de Participação mostra, o FPE aumentou 330\% desde seu nível mais baixo, no período 1969-75, até os percentuais definidos na CF-88. A CF-88 aumentou o total de dotação para esse fundo em $53 \%$ em relação aos $14 \%$ em vigor antes de 1988. Em resumo, uma das características do desenho fiscal adotado pelos constituintes foi o aumento do montante global das transferências fiscais, particularmente as transferências que promoviam a redistribuição interregional de renda, ou seja, os fundos de participação. As decisões relacionadas com esse desenho ocorreram fundamentalmente nas duas primeiras instâncias decisórias da constituinte de 1988 responsáveis por definir o sistema fiscal, ou seja, a Subcomissão de Tributos, Participação e Distribuição de Receitas (STPDR) e a Comissão do Sistema Tributário, Orçamento e Finanças (CSTOF). Passa-se agora a investigar o porquê dessas decisões sobre aumento das transferências redistributivas que foram tomadas na subcomissão e na comissão, bem como daquelas relacionadas com as outras dimensões do desenho fiscal, a saber, a definição da área de tributação própria, da autoridade para legislar sobre os próprios impostos, da autoridade residual e da vinculação dos gastos. Antes disto, seguem as principais propostas que estavam sendo debatidas na Subcomissão.

As propostas de sistema fiscal na Subcomissão de Tributos, Participação e Distribuição de Receita

Assim como as outras subcomissões, a STPDR promoveu audiências públicas com especialistas e entidades relacionadas com o tema de competência da subcomissão. Havia três principais propostas completas de desenho do sistema fiscal apresentadas nas audiências públicas da STPDR. Uma delas havia sido apresentada pela equipe do IPEA, sob coordenação de Fernando Rezende. A segunda pela Federação das Associações de Fiscais de Tributos Estaduais (FAFITE) com colaboração da União Nacional dos Auditores do Tesouro Federal (UNAFISCO), foi elaborada por uma comissão formada por quatro fiscais de tributos estaduais do Rio Grande do Sul. A terceira foi uma proposta apresentada pelos 
Secretários de Fazenda ou Finanças dos Estados e dos Territórios Federais das regiões Norte, Nordeste e Centro-Oeste. Além dessas três propostas, a comissão tinha como alternativa manter a estrutura fiscal vigente, já exposta, que representava a opção pelo status quo, ou adotar a proposta de sistema tributário que constava no Projeto Afonso Arinos. Os parágrafos seguintes discutem essas propostas a partir do instrumental conceitual desenvolvido na seção anterior.

\section{A Proposta do IPEA}

A proposta da equipe do IPEA, liderada por Fernando Rezende, era bastante detalhada. Reunia ideias de diversos autores, entre economistas, juristas e tributaristas. Era resultado de diversas reuniões e estudos que ocorreram desde meados de 1985, iniciada na Secretaria de Planejamento (SEPLAN) do estado do Paraná. O documento continha diversas estimativas e tabelas com dados sobre a arrecadação pública dos anos 70 e 80 . Nesse sentido, era a mais completa. Do ponto de vista federativo, a proposta criticava a centralização fiscal vigente, apontando que "a centralização fiscal aumentou ininterruptamente a partir de meados dos anos 60" (IPEA, 1987, p.3). Assim, defendia que um dos princípios da proposta era a "autonomia federativa, traduzida em maior equilíbrio entre a repartição das receitas fiscais, as fontes geradoras de recursos e as necessidades mínimas de gasto" (idem, p. 5).

Na dimensão da área de tributação própria, propunha uma ampla descentralização da arrecadação dos impostos. A principal modificação era agregar ao ICM o IPI e o ISS, criando o Imposto sobre o Valor Agregado (IVA), a ser cobrado pelos estados. No lugar do IPI, a União ficaria com um imposto especial sobre fumo, bebidas e veículos automotores.

Na dimensão das transferências fiscais, a proposta tinha a intenção de atenuar as desigualdades regionais e equilibrar a descentralização da arrecadação de impostos via aumento da área de tributação própria das subunidades. Por isso, dava ênfase às transferências horizontais, ou redistributivas, que só seriam obtidas via manutenção da 
centralização "de determinado volume de recursos sob competência da União" (IPEA, 1987, p.25). Propõe os chamados Fundos de Equalização estaduais e municipais (FEE e FEM, respectivamente) para substituir os fundos existentes, cuja base deveria englobar a totalidade de impostos que ficassem sob competência da União. A proposta também previa o Fundo Social, para atender a programas sociais de âmbito nacional.

A proposta criticava os critérios de repartição dos fundos como sendo obscuros e desatualizados, e as transferências negociadas como sendo mecanismos de diminuição da autonomia de gasto dos governos subnacionais. Para a repartição dos fundos, propunha que as cotas estaduais fossem calculadas de modo inversamente proporcional à receita estadual per capita e, para os municípios, inversamente proporcional à sua cota no IVA que seria distribuída proporcionalmente. A regra anterior, como será mais bem discutido, distribuía o Fundo dos Estados com uma fórmula (ver Apêndice) que considerava o inverso da renda per capita, não da receita.

Também criticava a excessiva centralização nas dimensões do policy-decision making do sistema fiscal. Na dimensão da vinculação dos gastos, propunha que o uso das receitas próprias oriundas das áreas de tributação exclusiva, bem como aquelas oriundas das transferências, fosse de inteira responsabilidade do ente subnacional, com exceção do Fundo Social, cuja vinculação seria completamente definida pelos programas sociais da União. O poder residual para criar tributos, por seu turno, ficaria a cargo dos estados e da União. Ou seja, ambos poderiam criar impostos quando a Constituição fosse omissa. Porém, se a União viesse a tributar uma área que o estado estivesse tributando pelo uso do poder residual, o imposto estadual seria anulado. 0

QUADRO 4 - PROPOSTA DO IPEA - AUTORIDADE FISCAL resume os principais pontos da proposta no que diz respeito à dimensão da autoridade fiscal. A dimensão do policy making, ou seja, a área de tributação própria e as transferências fiscais estão mais adiante, no QUADRo 7 - PROPOSTAS NA STPDR SOBRE ÁREA DE TRIBUTAÇ̃̃o EXCLUSIVA e no QUADRO 8 - PROPOSTAS NA STPDR SOBRE TRANSFERÊNCIAS FISCAIS, que compara todas as propostas. 
QUADRO 4 - PROPOSTA DO IPEA - AUTORIDADE FISCAL

\begin{tabular}{|c|c|c|c|}
\hline & $\begin{array}{l}\text { Autoridade } \\
\text { Residual }\end{array}$ & $\begin{array}{l}\text { Autoridade sobre imp. } \\
\text { próprio }\end{array}$ & $\begin{array}{l}\text { Vinculação de gastos de } \\
\text { receita }\end{array}$ \\
\hline UNIÃO & $\begin{array}{l}\text { Sim (prevalece o } \\
\text { federal) }\end{array}$ & $\begin{array}{l}\text { Sim } \\
\text { Regula alíquota do ITBI } \\
\text { estadual, base de cálculo e fato } \\
\text { gerador } \\
\text { Pode estabelecer isenções do } \\
\text { IVV municipal }\end{array}$ & $\begin{array}{l}\text { Regula totalmente os gastos do } \\
\text { Fundo Social }\end{array}$ \\
\hline ESTADOS & $\begin{array}{l}\text { Sim (prevalece o } \\
\text { federal) }\end{array}$ & Sim, com restrições do ITBI & $\begin{array}{l}\text { Autonomia para gasto dos } \\
\text { recursos próprios e de } \\
\text { transferências, exceto Fundo } \\
\text { Social } \\
\text { Autonomia para gasto dos } \\
\text { recursos próprios e de } \\
\text { transferências, exceto Fundo }\end{array}$ \\
\hline MUNICIPIOS & & Sim, com restrições do IVV & Social \\
\hline
\end{tabular}

Fonte: IPEA (1987)

\section{Proposta da FAFITE}

A proposta da FAFITE foi elaborada por fiscais do Rio Grande do Sul após várias reuniões, e foi criada a partir do projeto do IPEA e do projeto Afonso Arinos ${ }^{5}$. Uma das preocupações centrais da proposta era preservar e facilitar a arrecadação.

Na dimensão da área de tributação própria, a proposta da FAFITE modificava bastante o status quo e se distinguia bastante das outras. A maior modificação, e segundo os próprios autores o ponto principal da proposta, era a criação do Imposto sobre Operações Relativas à Circulação de Mercadorias e Prestação de Serviços (ICMPS), de competência exclusiva dos estados. Esse imposto integraria muitos outros, à semelhança da proposta do IPEA. O IPI seria integrado nele, com exceção do imposto sobre fumo, bebidas veículos e alguns combustíveis. Estes ficariam com a União, sob o rótulo de Imposto sobre Produtos Especiais (IPE). A proposta também integrava ao ICMPS o ISS e os impostos únicos (IUM, IUCL, o IUEE, ISC e o IT).

\footnotetext{
${ }^{5}$ Há inclusive um quadro comparativo entre a Constituição em vigor, o Projeto Afonso Arinos e a proposta da FAFITE no final da proposta desta instituição.
} 
Quanto às transferências verticais, a proposta previa a criação de quatro fundos. 0 primeiro seria o fundo de equalização, com maior potencial redistributivo, que visava a garantir um piso mínimo de recursos per capita para os estados pobres. Tinha a preocupação, no entanto, de criar mecanismos para que a transferência para esses estados não culminasse em preguiça fiscal. O segundo seria o Fundo Social, um fundo cuja destinação seria totalmente definida pela União, vinculando áreas de aplicação: saúde, educação, etc. O terceiro seria o fundo de descentralização, que visava garantir recursos para a descentralização de competências sobre políticas, também prevista na proposta do IPEA. A proposta discutia, porém, com muito mais cuidado, o quarto fundo: o Fundo de Ressarcimento às Exportações. Conforme argumentam na própria proposta, "esta é uma matéria que assume enorme importância para os estados superavitários com o comércio exterior. [...] Como as exportações continuarão, [...], a serem desoneradas, tal tratamento implica prejuízo aos estados que possuem em sua economia uma significativa participação no comércio internacional" (FAFITE, 1988). Demanda, assim, ressarcimento das desonerações de incentivo à exportação na proporção superavitária da balança de exportações do estado. O relatório da FAFITE apresentava inclusive estimativas sobre o montante em questão. Os percentuais globais dos fundos seriam calculados sobre a receita fiscal total da União.

A proposta era bastante genérica quanto aos fundos redistributivos. Dizia apenas que lei complementar deveria regular seus percentuais e critérios de rateio. Sobre as transferências horizontais defendia critérios diferentes para cada um dos quatro fundos que propunha. No Fundo Social, previa beneficiar municípios de médio porte, com o argumento que municípios pequenos e pobres já receberiam o Fundo de Equalização, e os grandes possuiriam maior potencial fiscal. Do mais, apenas apontavam que lei complementar deveria definir os critérios de rateio, em especial do fundo de equalização.

Na dimensão da autoridade para legislar sobre os próprios impostos entregavam à União a prerrogativa de regular o ITBI municipal e definir fatos geradores do ICMS. A alíquota deste, a ser aprovada pelo Senado, deveria resultar de proposta de um colegiado estadual. 
Na dimensão da autoridade sobre os gastos, defendia a proibição da vinculação das transferências. A autoridade residual, na proposta, ficava com a União.

O QUADRo 5 - PROPOSTA DA FAFITE - AUTORIDADE FISCAL resume os pontos da proposta que mais nos interessam aqui, na dimensão da autoridade fiscal. No geral, a proposta aumentava a área de tributação própria dos estados, o que favorecia as subunidades com base taxável maior.

\section{QUADRO 5 - PROPOSTA DA FAFITE - AUTORIDADE FISCAL}

\begin{tabular}{|c|c|c|c|}
\hline & $\begin{array}{l}\text { Autoridad } \\
\text { e Residual } \\
\end{array}$ & $\begin{array}{c}\text { Autoridade sobre imp. Outras } \\
\text { subunidades }\end{array}$ & $\begin{array}{l}\text { Vinculação de gastos de } \\
\text { receita }\end{array}$ \\
\hline \multirow[t]{3}{*}{ UNIÃO } & Sim & Alíquota do ITBI definida pela união & $\begin{array}{l}\text { Proibida de vincular os recursos } \\
\text { de transferências ou do ICMPS, } \\
\text { com exceção do Fundo Social }\end{array}$ \\
\hline & & Define fato gerador do ICMPS & \\
\hline & & $\begin{array}{l}\text { Alíquota ICMS definida pelo Senado, } \\
\text { mediante proposta de órgão colegiado } \\
\text { estadual }\end{array}$ & \\
\hline ESTADOS & Não & $\begin{array}{l}\text { Sim, com as exceções destacadas na } \\
\text { linha da União acima }\end{array}$ & $\begin{array}{l}\text { Autonomia de gasto, com } \\
\text { exceção do Fundos Social e } \\
\text { proibido de vincular os recursos } \\
\text { das transferências para } \\
\text { municípios }\end{array}$ \\
\hline MUNICIPIO & & Sim, com as exceções destacadas na & Autonomia de gasto com \\
\hline$S$ & Não & linha da União acima & exceção do Fundo Social \\
\hline
\end{tabular}

\section{Proposta dos Secretários de Fazenda dos Estados do Norte, Nordeste e} Centro-Oeste

Os Secretários de Fazenda dos Estados do Norte, Nordeste e Centro-Oeste se reuniram entre 24 e 25 de abril de 1987 em Manaus com a finalidade específica de discutir a reforma fiscal da constituinte, o sistema em funcionamento e a proposta do IPEA. $O$ intuito era apresentar, com base nos debates, uma proposta alternativa de sistema fiscal. A proposta elaborada, da qual todos os estados dessas regiões eram signatários, foi 
apresentada por Ozias Monteiro Rodrigues, secretário de Fazenda do Estado do Amazonas, em uma das audiências públicas da STPDR.

Na dimensão das áreas de competência própria, defendia que o IPI permanecesse como estava, bem como o sistema de cobrança do IVA (ICM). A opção de não modificar o IPI está relacionada diretamente com o problema da redistribuição interregional. O IPI é um dos principais componentes do FPE, juntamente com o IR. Descentralizar sua cobrança, conforme a proposta do IPEA, significava diminuir o montante de recursos nas mãos da União passível de redistribuição interregional via transferências.

Na dimensão das transferências fiscais, em sua dimensão vertical, a proposta aumentava para $22 \%$ a participação dos Estados nos Impostos da União, mas não só no IPI e IR, como no status quo, mas também sobre sete impostos federais, inclusive IPI e IR, além das contribuições de intervenção no domínio econômico. Aquiescia em relação à proposta do IPEA no que diz respeito a transferir para os estados o ISS e incorporá-lo no ICM, bem como incorporar neste imposto os impostos únicos federais (IUEE, IUM, IUCL, IT). Também propunha aumentar a transferência do ICM dos estados para os municípios para $25 \%$, compensando a transferência do ISS para o nível estadual. Propunha a extinção do salário educação e do Finsocial. Criava também o Fundo de Descentralização, temporário, para custear a descentralização de políticas, novamente, sem se diferenciar nesse ponto da proposta do IPEA e da FAFITE.

Em sua dimensão horizontal, queria garantir os critérios de rateio dos fundos entre os estados na Constituição. Propunha que o critério de rateio estadual continuasse conforme as regras em vigor (ver anexo A), isto é, que $5 \%$ fosse distribuído proporcionalmente à população, mas que os outros $95 \%$ fossem distribuídos de modo inversamente proporcional à receita tributária per capita. Como já apontado, a regra em vigor definia 95\% inversamente proporcional à renda per capita dos estados. Como se verá na seção seguinte, para o caso dos estados, essa modificação não é trivial. As duas únicas transferências que promoveriam redistribuição interregional seriam essas. Curiosamente, não diz nada sobre o Fundo Especial. 
Na dimensão da vinculação de gastos da receita, proibia qualquer vinculação de gastos tanto para as transferências quanto para as áreas de tributação própria. Também defendia que a União e os estados fossem constitucionalmente proibidos de conceder isenções em áreas de competência própria de outras unidades.

O QuAdRo 6 - Proposta dos SECRETÁrios da FAZENDA dos ESTAdos dA REgIão NO, NE $\underline{\text { E CO }}$ apresenta a proposta de modo resumido na dimensão da policy decision-making.

\section{QUADRO 6 - PROPOSTA DOS SECRETÁRIOS DA FAZENDA DOS ESTADOS DA REGIÃO NO, NE E CO - AUTORIDADE FISCAL}

\begin{tabular}{|c|c|c|c|}
\hline & $\begin{array}{l}\text { Autoridade } \\
\text { Residual }\end{array}$ & $\begin{array}{l}\text { Autoridade sobre imp. } \\
\text { próprio }\end{array}$ & $\begin{array}{l}\text { Vinculação de gastos de } \\
\text { receita }\end{array}$ \\
\hline \multirow[t]{4}{*}{ UNIÃO } & $\begin{array}{l}\text { Sim (exclui estadual } \\
\text { caso exista) }\end{array}$ & $\begin{array}{l}\text { Senado regula ICM } \\
\text { interestadual uniforme, } \\
\text { estabelecida por iniciativa da } \\
\text { maioria absoluta dos } \\
\text { governadores }\end{array}$ & $\begin{array}{l}\text { Proíbe vinculação de receita } \\
\text { das transferências para estados } \\
\text { e municípios }\end{array}$ \\
\hline & & $\begin{array}{l}\text { Senado regula piso do ICM } \\
\text { intraestadual }\end{array}$ & \\
\hline & & $\begin{array}{l}\text { Proibida de conceder isenções } \\
\text { à área de competência de } \\
\text { outra subunidade }\end{array}$ & \\
\hline & & $\begin{array}{l}\text { União define fato gerador do } \\
\text { ICM e sua base de cálculo }\end{array}$ & \\
\hline ESTADOS & $\begin{array}{l}\text { Sim (mas um imposto } \\
\text { federal idêntico pode } \\
\text { anulá-lo) }\end{array}$ & $\begin{array}{l}\text { Sim, com as limitações } \\
\text { apresentadas na linha acima. } \\
\text { Proibido de conceder isenções } \\
\text { à área de competência de } \\
\text { outra subunidade }\end{array}$ & $\begin{array}{l}\text { Proíbe vinculação de receita } \\
\text { das transferências para } \\
\text { municípios }\end{array}$ \\
\hline MUNICIPIOS & Não & - & - \\
\hline
\end{tabular}

Fonte: Sileg: arquivos da constituinte. Proposta dos secretários de Fazenda dos estados do NO, NE e CO apresentada a STPDR.

(1) Mesmo se for área privativa dos estados ou municípios

A proposta dos secretários de fazenda dos estados do Norte, Nordeste e CentroOeste, como fica claro, deixa vários impostos nas mãos da União, e intensifica a redistribuição via transferências. A proposta vincula todos os impostos às transferências, não apenas o IPI e IR, como faz o IPEA, com a diferença de que aqui a descentralização via aumento da área de tributação própria é bem menos importante, resultando um bolo 
maior de impostos com arrecadação centralizada e, portanto, sujeitos à redistribuição interregional (dados que comparam as propostas estão apresentados logo na sequência).

\section{O Projeto Afonso Arinos}

O Projeto Afonso Arinos foi elaborado por uma Comissão Provisória de Estudos Constitucionais $^{6}$ em 1985. Essa comissão apresentou um anteprojeto de constituição, que ficou conhecido como Projeto Afonso Arinos, pois a Comissão Provisória foi presidida por Afonso Arinos de Melo Franco.

Na dimensão das áreas de competência própria, o Projeto Afonso Arinos deixava nas mãos da União os impostos únicos que nos outros projetos foram transferidos para âmbito estadual, incorporados ao ICM. A União ficava com 13 impostos no total, os estados com seis, e os municípios com cinco. Nesse aspecto, o projeto mantinha o status quo sem grandes alterações.

Na repartição vertical da receita pública, as alterações ocorreram mais no sistema de transferências fiscais do que nas áreas de competência própria. Na dimensão vertical das transferências, o projeto Afonso Arinos aumentava o percentual dos impostos únicos a serem transferidos para os estados, a serem distribuídos proporcionalmente, bem como os percentuais de transferências para os municípios. Entretanto, a descentralização não era tão expressiva quanto a das outras propostas apresentadas. O projeto Afonso Arinos era omisso quanto à repartição horizontal das transferências fiscais, delegando qualquer decisão para lei complementar.

$\mathrm{Na}$ dimensão da autoridade residual, entregava aos estados e à União essa competência. Na dimensão da autoridade para regular as áreas de tributação própria, a União ficava com prerrogativas substanciais, como a de definir alíquotas máximas para o ICM estadual e para o IVV municipal. Em relação à vinculação de gastos, vinculava $6 \%$ do FPM para a saúde e não proibia expressamente a União de vincular outros percentuais.

\footnotetext{
${ }^{6}$ Brasil. Presidência da República (1985).
} 
Comparação das propostas

As propostas não se diferenciam substancialmente na dimensão da policy decisionmaking. Todas de algum modo proibiam a União de vincular parte substancial da receita dos estados, seja de transferência, seja a receita própria. A vinculação do gasto ocorria em uma parte menos substancial da receita das subunidades. As propostas do IPEA e da FAFITE, por exemplo, vinculavam os gastos do Fundo Especial. O Projeto Afonso Arinos, por seu turno, era omisso na proibição das vinculações. Na questão do poder residual, apenas a proposta da FAFITE negava o poder residual aos estados.

Já na dimensão da distribuição vertical e horizontal das receitas, as propostas apresentavam maior discrepância. A principal diferença das propostas na dimensão da área de tributação própria dizia respeito ao IPI. Esse imposto era a segunda maior fonte de receita fiscal da União, depois do IR. As propostas do IPEA, da FAFITE e do projeto Afonso Arinos defendiam a descentralização de sua arrecadação e sua incorporação ao ICM estadual. Na definição dos impostos estaduais, essa divergência se traduzia nas diferentes propostas para reforma do ICM estadual. A proposta dos secretários de fazenda do Norte, Nordeste e Centro-Oeste mantinha a arrecadação do IPI centralizada, como foi ao final adotado.

Ainda mais discrepantes eram as propostas em relação à dimensão das transferências fiscais. O QUADRO 7 - PROPOSTAS NA STPDR SOBRE ÁREA DE TRIBUTAÇÃO EXCLUSIVA e O QUADRO 8 - PROPOSTAS NA STPDR SOBRE TRANSFERÊNCIAS FISCAIS apresentam um comparativo da área de tributação exclusiva e das transferências fiscais (verticais e horizontais) em relação ao status quo. 
QUADRO 7 - PROPOSTAS NA STPDR SOBRE ÁREA DE TRIBUTAÇÃO EXCLUSIVA

\begin{tabular}{|c|c|c|c|c|c|c|}
\hline & Status Quo & $\begin{array}{l}\text { S.Fazenda } \\
\text { NO,NE, CO }\end{array}$ & Afonso Arinos & IPEA & FAFITE & CN1988 \\
\hline \multirow[t]{10}{*}{ União } & Imp. Renda (IR) & $\underline{\underline{I R}}$ & $\underline{\underline{I R}}$ & $\underline{\underline{I R}}$ & 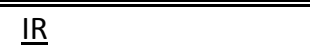 & $\underline{\underline{I R}}$ \\
\hline & Imp. Exp (IE) e Import. (II) & $\underline{\mathrm{II}, \mathrm{IE}}$ & $\underline{\mathrm{II}, \mathrm{IE}}$ & $\underline{\mathrm{II}, \mathrm{IE}}$ & Imp. Com. Ext.(IE+II) & $\underline{I I, I E}$ \\
\hline & Imp. Op. Financeiras (IOF) & $\overline{\mathrm{IOF}}$ & $\overline{\mathrm{IOF}}$ & $\overline{\mathrm{IOF}}$ & $\underline{\mathrm{IOF}}$ & $\overline{\mathrm{IOF}}$ \\
\hline & Imp. Prod. Ind. (IPI) & IPI & $I E C(2)$ & IFBV (4) & IPE (8) & IPI \\
\hline & & $\operatorname{IPL}(1)$ & & $I P L$ & $I P L$ & \\
\hline & & $\begin{array}{l}\text { ITBI "causa- } \\
\text { mortis" }\end{array}$ & & ITBI "causa-mortis" & & \\
\hline & & & & & $I H D(7)$ & \\
\hline & Imp. Territorial Rural (IPTR) & & IPTR & & & IPTR \\
\hline & & & IPBMS(3) & & & \\
\hline & Impostos Únicos (IUs) (5) & & Impostos Únicos (IUs) & & & \\
\hline \multirow[t]{6}{*}{ Estados } & ICM & ICMS & ICM & IVA & ICMPS & ICMS \\
\hline & IPVA & IPVA & IPVA & IPVA & & IPVA \\
\hline & ITBI & IBTI "Inter-vivos" & ITBI "interv." e "causa-mor" & ITBI "intervivos" & & ITBI "causa-mortis" \\
\hline & & IRRF & IRRF & & IRRF & IRRF \\
\hline & & $\begin{array}{l}\text { 5\% IR de Pes. } \\
\text { Juríd. } \\
\text { IPTR }\end{array}$ & & $\begin{array}{l}\text { 5\% Adicional sobre } \\
\text { IR } \\
\text { IPTR }\end{array}$ & & $5 \%$ adic. sobre IR \\
\hline & & & IT intermunicipal & & & $\operatorname{IGC}(6)$ \\
\hline
\end{tabular}




\begin{tabular}{|c|c|c|c|c|c|c|}
\hline & Status Quo & $\begin{array}{l}\text { S.Fazenda } \\
\text { NO,NE, CO }\end{array}$ & Afonso Arinos & IPEA & FAFITE & CN1988 \\
\hline \multirow[t]{7}{*}{ Municípios } & ISS & & ISS & & & ISSQ \\
\hline & $\underline{\text { IPTU }}$ & IPTU & IPTU & $\underline{\text { IPTU }}$ & $\underline{\text { IPTU }}$ & $\underline{\text { IPTU }}$ \\
\hline & & $\begin{array}{l}\text { IVV de Comb. Líq. e } \\
\text { Gás. }\end{array}$ & IVV & IVV & & IVVC \\
\hline & & IRRF & IRRF & & IRRF & IRRF \\
\hline & & & & & IBTI & ITBI "inter-vivos" \\
\hline & & & & & IPTR & \\
\hline & & & $\mathrm{ISLI}^{(9)}$ & & & \\
\hline
\end{tabular}

\section{Fonte:}

(1) Imposto anual sobre patrimônio Líquido das Pessoas Físicas

(2) Imp. Especial Consumo. Lei complementar iria definis os produtos incluídos na base desse imposto

(3) Imp. Propriedade de bens Móveis Suntuários

${ }^{(4)}$ Imp. fumo, bebidas, veículos

${ }^{(5)}$ Imp. único Energia Elétrica (IUEE), Imp. único Prod. Minerais (IUM),Imp. único Comb. e Lubrificantes (IUCL), Imp. Serv. de Comunicação (ISC), Taxa Transporte (IT)

(6) Imp. ganhos suplementares de capital

(7) Imp. Heranças e Doações

(8) Imp. Produtos Especiais

(9) Imposto sobre locação de imóveis 
QUADRO 8 - PROPOSTAS NA STPDR SOBRE TRANSFERÊNCIAS FISCAIS

\begin{tabular}{|c|c|c|c|c|c|}
\hline Status Quo & $\begin{array}{c}\text { S.Fazenda NO,NE, } \\
\text { CO }\end{array}$ & Afonso Arinos & IPEA & FAFITE & CN 1988 \\
\hline \multicolumn{6}{|c|}{ "DA UNIÃO PARA ESTADOS } \\
\hline $\begin{array}{l}14 \% \text { IPI e IR (FPE) } \\
\end{array}$ & $22 \%$ de todos imp. ${ }^{(1)}$ & 14\% IEC e IR (FPE) & 9\% FE dos estados & Fundo de Equalização & 21,5\% IPI e IR (FPE) \\
\hline 50\% IUEE & & $60 \%$ IUEE & & & \\
\hline $70 \%$ IUM & & $90 \%$ IUM & & & \\
\hline $40 \%$ IUCL & & $60 \%$ IUCL & & & \\
\hline \multirow[t]{7}{*}{$50 \%$ IT } & & $50 \%$ IT & & & \\
\hline & 1/3 Imp.Residual & $30 \%$ imp.residual p/ FPE & $1 / 3$ Imp. residual & & $20 \%$ imp. residual \\
\hline & & $50 \%$ IOF & & & \\
\hline & & $2 \% \mathrm{FE}$ & & & \\
\hline & & & & Fundo de Ressarcimento & $10 \%$ IPI para FR ${ }^{(4)}$ \\
\hline & & & $5 \%$ Fundo Social & Fundo Social & \\
\hline & & & $\begin{array}{l}\text { Fundo de } \\
\text { Descentralização }\end{array}$ & Fundo de Descentralização & \\
\hline \multicolumn{6}{|c|}{ DA UNIÃO PARA MUNICIPIOS } \\
\hline $\begin{array}{l}17 \% \text { IPI e IR (FPM) } \\
\end{array}$ & $23 \%$ de todos imp ${ }^{(1)}$ & 17\% IEC e IR (FPM) & 10\% FE Municípios ${ }^{(5)}$ & Fundo de Equalização & 22,5\% IPI e IR (FPM) \\
\hline $10 \%$ IUEE & & $30 \%$ IPBMS $^{(3)}$ & & & - \\
\hline $10 \%$ IUM & & & & & - \\
\hline $20 \%$ IT & & $20 \% \mathrm{IT}$ & & & - \\
\hline $100 \%$ IPTR & & $80 \%$ IPTR & & & $50 \%$ IPTR \\
\hline \multirow[t]{5}{*}{$10 \%$ IUCL } & & $1 \%$ FERM $^{(2)}$ & & & \\
\hline & & $30 \%$ imp. residual p/ FPM & & & \\
\hline & & $50 \%$ IOF & & & \\
\hline & & & 5\% Fundo Social & Fundo Social & \\
\hline & & & & Fundo de Descentralização & \\
\hline
\end{tabular}

Continua... 


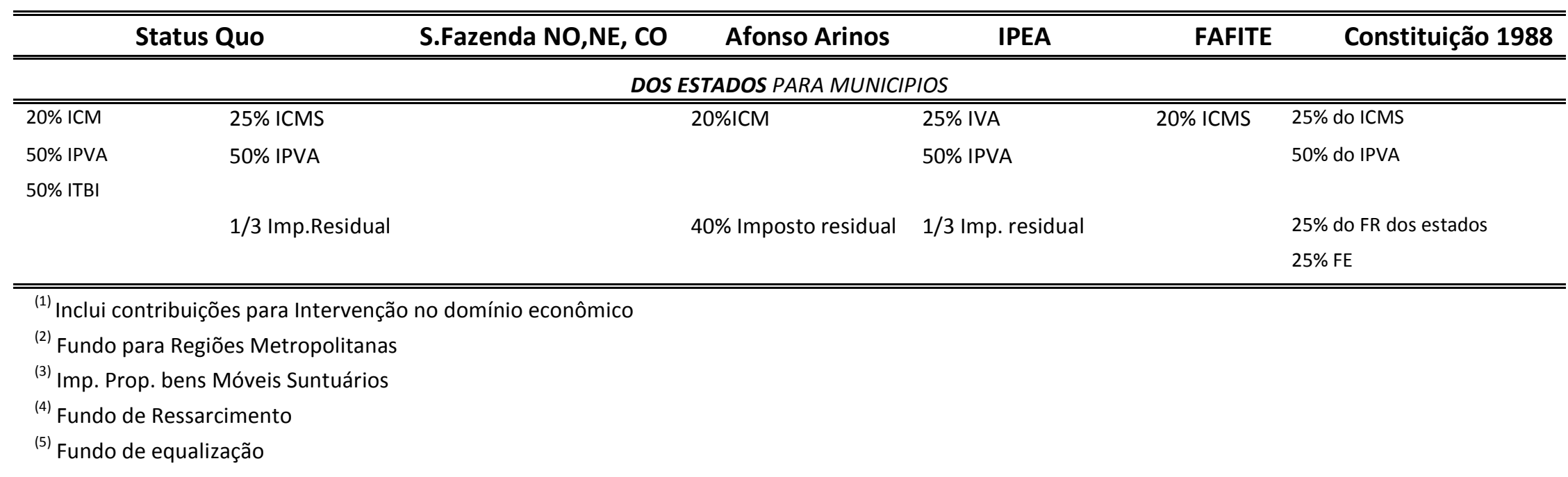


Como já discutido, os fundos de participação vigentes à época eram as principais transferências redistributivas da União para os estados. As outras transferências eram distribuídas por critérios proporcionais à arrecadação. Como o QUUARO 8 - PROPOSTAS NA STPDR SOBRE TRANSFERÊNCIAS FISCAIS mostra, a proposta que mais atenção dava às transferências do fundo de participação era a proposta dos secretários de fazenda do Norte, Nordeste e Centro-Oeste. Era justamente essa proposta que, expressamente criticando a proposta do IPEA, defendia que a arrecadação do IPI permanecesse nas mãos da União, sem alteração. Novamente, o IPI era o segundo principal imposto da União e compunha juntamente com o IR à base do FPE. Na proposta dos secretários de fazenda dos estados mais pobres, além de manter a arrecadação desse imposto centralizada, evitando perder receita do fundo, sua base seria ampliada para $22 \%$, e seria calculada sobre todos os impostos federais. A proposta do IPEA também defendia esse último ponto, mas reformava o IPI, incorporando-o ao ICM estadual, reduzindo assim a receita global da União e, por consequência, a base dos fundos de redistribuição. Ademais, a proposta do IPEA defendia que apenas $9 \%$ da receita fiscal da União fosse para o fundo de redistribuição (chamado de Fundo de Equalização). Ainda que aumentasse a receita dos estados com menor capacidade de geração de receita própria, a proposta do IPEA era menos redistributiva que a dos secretários de fazenda do Norte, Nordeste e Centro-Oeste.

\section{A TABELA 9 - RELAÇÃO ENTRE RECEITA PÚBLICA RESULTANTE DAS PROPOSTAS SOBRE RECEITA}

FISCAL NO STATUS QUO apresenta um comparativo entre o status quo e as propostas. Cada coluna da tabela apresenta o impacto de cada proposta sobre a distribuição vertical da receita no status quo. Como se pode ver pela tabela, a proposta dos secretários da fazenda dos estados mais pobres aumenta a receita dos estados oriunda de transferências redistributivas (Fundos de participação) redistributivas em 1,85 vezes. Já a proposta do IPEA aumenta a receita dessa mesma fonte em apenas 1,16. Os detalhes dos cálculos e as fontes dos dados estão no anexo. 
TABELA 9 - RELAÇÃO ENTRE RECEITA PÚBLICA RESULTANTE DAS PROPOSTAS SOBRE RECEITA FISCAL NO STATUS QUO

\begin{tabular}{lccccc}
\hline \hline & Sec.Faz. NO,NE e CO & AA & IPEA & FAFITE & CF 1988 \\
\hline \hline Área de Tributação exclusiva & & & & & 0,95 \\
União & 0,96 & 0,99 & 0,94 & 0,94 & 1,11 \\
Estados & 1,12 & 1,25 & 1,38 & 1,33 & 1,27 \\
Municípios & 0,76 & 1,35 & 0,76 & 0,70 & \\
\hline Transferências proporcionais & & & & - & 0,67 \\
da união p /Estados & - & 3,34 & - & - & 0,10 \\
da união p/ Municípios & - & 7,54 & - & & 1,53 \\
\hline Transferências redistributivas & & & & & 1,18 \\
da união p/ Estados & 1,85 & 1,10 & 1,16 & 1,16 \\
da união p/ Municípios & 1,63 & 0,88 & 1,05 & 1,05 & 1,35 \\
\hline Transferências proporcionais & & & & & 0,83 \\
do estado p/ Municípios & 1,32 & 0,88 & 1,62 & 1,23 & 1,11 \\
\hline Receita Federal Total & 0,73 & 0,84 & 0,93 & 0,93 & 1,25 \\
Receita Estadual Total & 1,17 & 1,38 & 1,24 & 1,27 & 1,04 \\
Receita Municipal Total & 1,32 & 1,10 & 1,22 & - & \\
\hline \hline
\end{tabular}

Fonte: IPEA, 1987-TD 108, Tabela III.4, pg. 38; TD 104, Tabela I.2, pg. 36, e Tabela A.I.2, pg.52; Elaboração própria AA: Projeto Afonso Arinos. Fonte

\section{A TABELA 9 - RELAÇ̃̃o ENTRE RECEITA PÚBLICA RESULTANTE DAS PROPOSTAS SOBRE RECEITA}

FISCAL NO STATUS QUO indica que todas as propostas transferiam receita da União para oS estados, mas não da mesma forma. O projeto Afonso Arinos, por exemplo, transferia a receita federal para os estados e municípios, mas era pouco redistributivo, porque descentralizava primordialmente através de transferências proporcionais à arrecadação. Já a proposta dos secretários da Fazenda do NO, NE e CO descentralizava primordialmente através dos fundos de redistribuição interregional.

\section{A FIGURA 2 - IMPACTO NA RECEITA ESTADUAL ESTIMADA DAS PROPOSTAS APRESENTADAS NA} STPDR EM RELAÇÃO AO STATUS QUO apresenta o argumento graficamente, cruzando os dados da TABELA 9 - RELAÇÃo ENTRE RECEITA PÚBLICA RESULTANTE DAS PROPOSTAS SOBRE RECEITA FISCAL NO STATUS QUO. Evidentemente, o aumento da área de tributação própria interessa mais para subunidades com maior capacidade de geração de recursos fiscais. Para unidades com baixa capacidade de arrecadação, é mais interessante garantir receita via transferências redistributivas interregionais. 


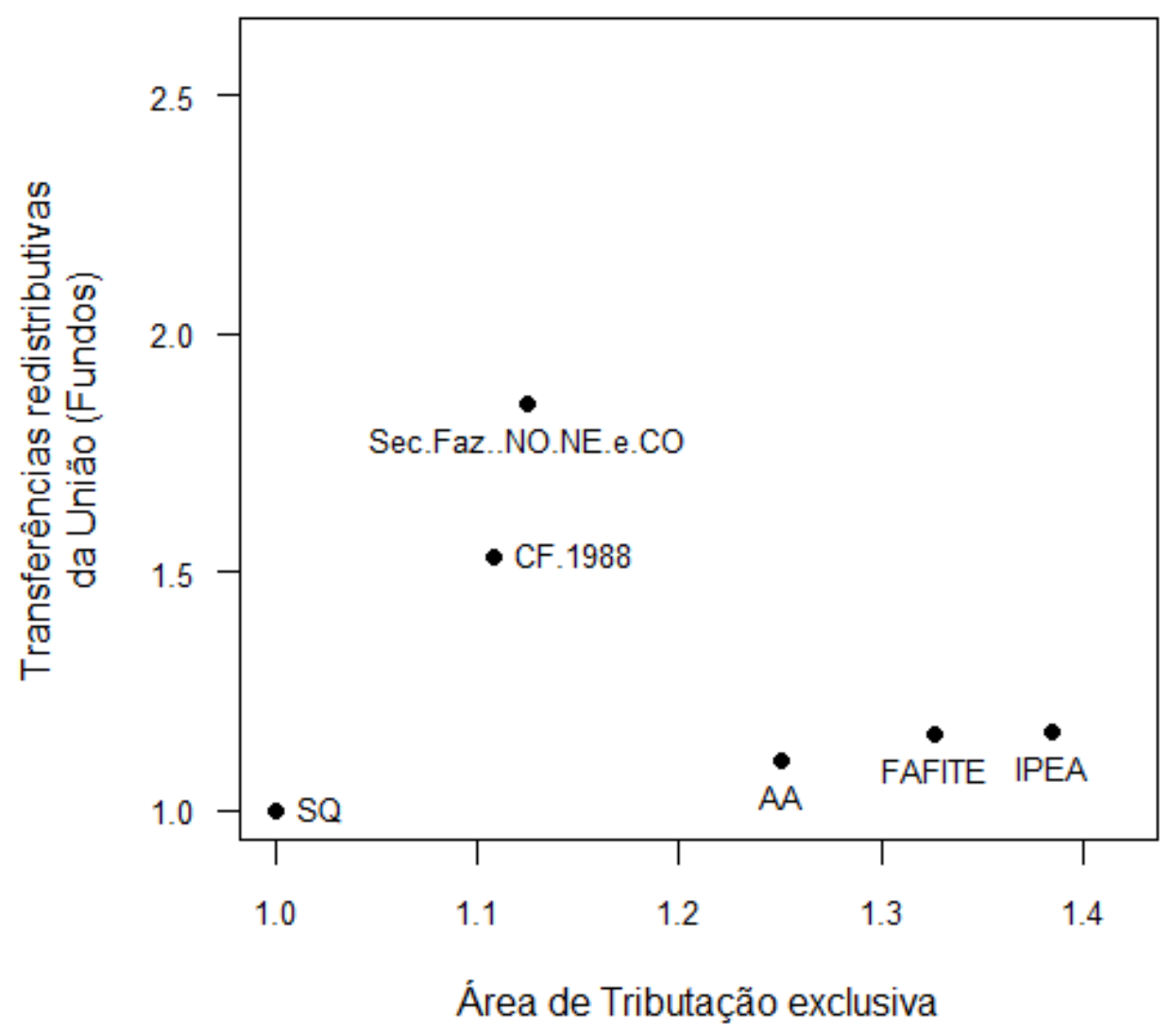

Como indica a FIGURA 3 - COMPARATIVO DAS PROPOSTAS DE DESCENTRALIZACÃo, na dimensão vertical da repartição de rendas públicas, a proposta dos secretários da Fazenda do Norte, Nordeste e Centro-Oeste era a que mais retirava recursos da União em termos de receita líquida ${ }^{7}$ em relação ao status quo, seja para o estado, seja para os municípios. Além disso, era a proposta mais municipalista em relação às outras.

\footnotetext{
${ }^{7}$ Receita líquida aqui é a receita tributária própria descontadas (somadas) as transferências enviadas (recebidas).
} 
FIGURA 3 - COMPARATIVO DAS PROPOSTAS DE DESCENTRALIZAÇÃO

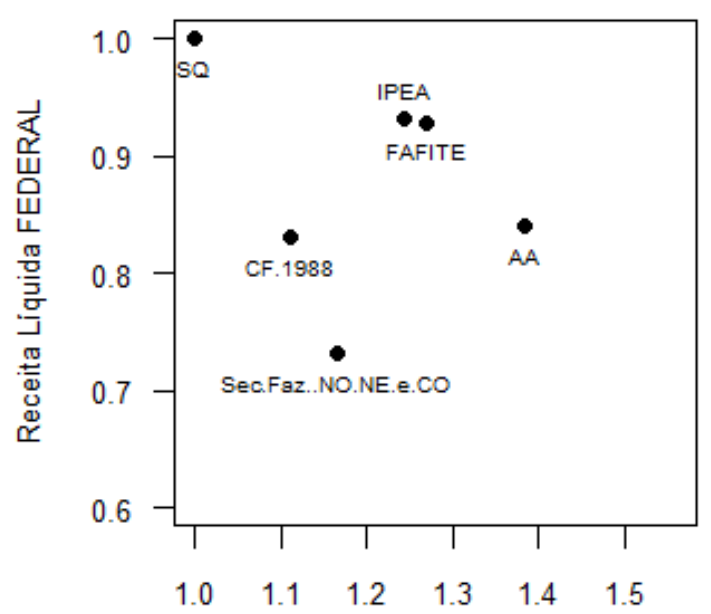

Receita Líquida ESTADUAL

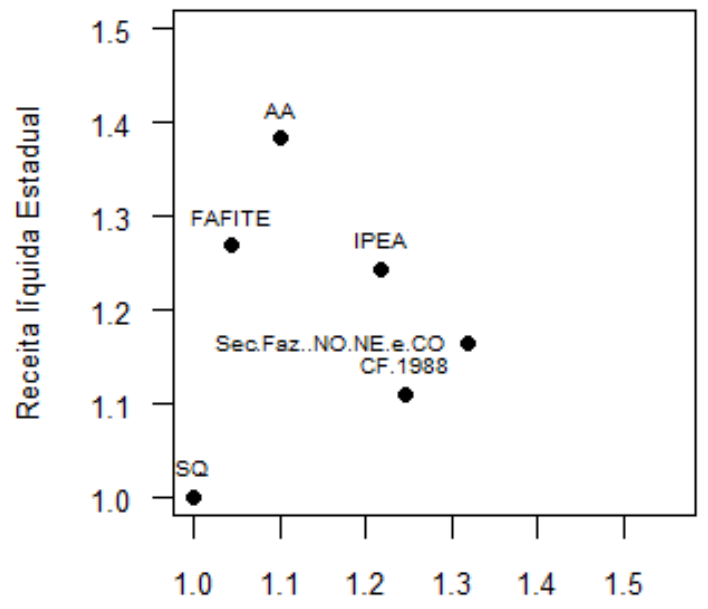

Receita líquida Municipal

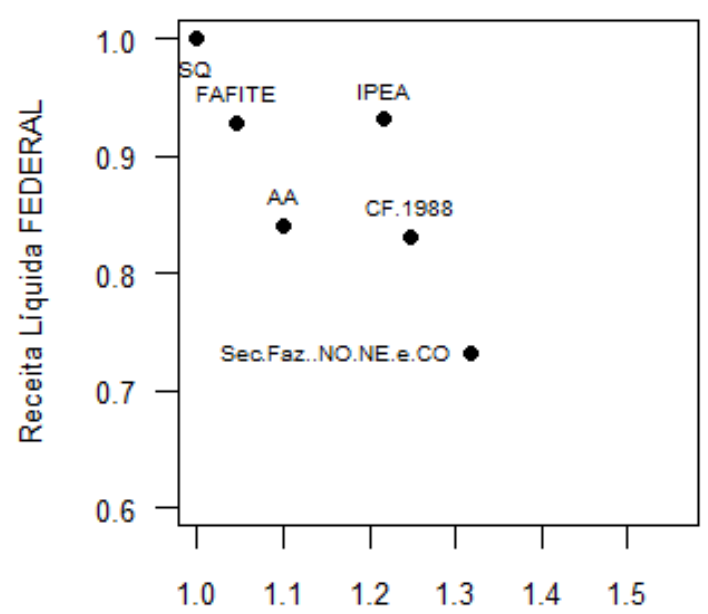

Receita Líquida MUNICIPAL 
Em resumo, todas as propostas aumentariam as receitas das subunidades e diminuiriam a da União. Porém, as propostas do IPEA, da FAFITE e do projeto Afonso Arinos, nessa ordem, descentralizavam receitas através do aumento na dimensão da área de tributação própria. A proposta dos secretários da fazenda do NO, NE e CO, por sua vez, estava mais próxima do status quo nessa dimensão. Porém, descentralizava a receita através de transferências redistributivas interregionais, ou seja, dos fundos de participação. Em outras palavras, a proposta dos secretários de fazenda do Norte, Nordeste e Centro-Oeste era não só mais descentralizadora, mas também redistributivista do ponto de vista interregional, porque concentrava o aumento de receita das subunidades via transferências através dos fundos de redistribuição. Do ponto de vista da receita estadual, fica claro pelas figuras 2 e 3 que a decisão final da Constituinte de 1988 ficou entre o status quo e essa proposta, em especial em relação ao tipo de descentralização da receita que foi adotado. A subseção seguinte explora o processo decisório para explicitar o porquê desse resultado.

\subsection{As duas coalizões regionais na Subcomissão de Tributos, Participação e Distribuição de Receita}

Antes de qualquer reunião da Subcomissão de Tributos, Participação e Distribuição de Receitas (STPDR), os parlamentares que estavam designados para participar dessa subcomissão e da Comissão do Sistema Tributário, Orçamento e Finanças (CSTOF) se reuniram para eleger os presidentes e vices. Nessa primeira reunião ocorreram disputas regionais pelos cargos centrais dessas arenas, ou seja, presidência e relatoria.

As bancadas do Norte e Nordeste reagiram contra as escolhas dos líderes partidários para os cargos-chave. Essa disputa tinha como pano de fundo a preocupação clara com a divisão das rendas públicas que seria decidida nessas instâncias. Havia uma preocupação em distribuir os cargos parlamentares de modo a representar suas regiões adequadamente nas instâncias decisórias, mas esta distribuição foi concebida no interior dos partidos e por suas lideranças. 
Mussa Demes (PFL/PI) aponta o principal aspecto do problema. As escolhas das lideranças partidárias sobre a distribuição dos cargos na CSTOF e nas suas subcomissões resultaria em total alijamento do Norte e Nordeste da Comissão de Sistematização (CSist). Pela regra, iriam para a Comissão de Sistematização presidente e relator das Comissões, bem como relatores das subcomissões. Os nomes eram Francisco Dornelles (PFL/RJ) para presidente da CSTOF e Jose Serra (PMDB/SP) para relator. Ou seja, presidente e relator da comissão seriam constituintes da região Sudeste. Na presidência da STPDR estaria Benito Gama (PFL/BA) e Irajá Rodrigues (PMDB/RS) seria o relator.

Ficou acordado na reunião que as bancadas do Norte e Nordeste se articulariam com as lideranças partidárias para indicar relatores nas Subcomissões da CSTOF que fossem do Norte e/ou Nordeste. Ao fim e ao cabo, foi escolhido para a STPDR como presidente Benito Gama (PFL/BA) e como relator Fernando Bezerra Coelho (PMDB/PE). Na Subcomissão do Orçamento e Fiscalização Financeira, ficou como presidente João Alves (PFL/BA) e relator José Luiz Maia (PDS/PI). Finalmente, a Subcomissão do Sistema Financeiro foi presidida por Cid Sibóya de Carvalho (PMDB/CE) e teve como relator o constituinte Harlan Gadelha (PMDB/PE). Ou seja, de nenhum relator daquelas regiões, as três subcomissões passaram a contar com presidente e relator oriundos de estados do Nordeste.

A STPDR realizou seus trabalhos entre maio e abril de 1987 e contou com audiências públicas de diversos especialistas, cujas principais propostas já foram discutidas aqui, na seção anterior. Uma das principais preocupações expressas pelos constituintes era o impacto das modificações nas receitas públicas. Demandavam simulações e quantificação das modificações. O constituinte Simão Sessim (PFL/RJ), arguindo a exposição do Sr. Fernando Rezende, que expunha a proposta do IPEA, reforçou a necessidade de disporem os constituintes de cálculos que informassem a dimensão das perdas e ganhos com a reforma. A necessidade de simulações dos resultados de modo a reduzir a incerteza do impacto da decisão foi enfatizada por diversos parlamentares. Diz Simão Sessim (PFL/RJ): 
"Quanto à questão do aumento da carga tributária, da sua distribuição e do balanço de ganhos e perdas, acho que é extremamente importante, a despeito de inúmeras dificuldades que todos que trabalham nessa área têm para conciliar estatísticas existentes e estabelecer cálculos muito precisos. Estamos trabalhando, e ainda intensamente, na tentativa de apuração desses números, com base na apuração de 1984, o último ano para o qual foi possivel obter informações sobre a receita de todos os tributos em todos os níveis de governo, de forma a se ter o sistema como um todo. Nossa preocupação, de início, não foi calcular um aumento de carga tributária global, mas, sim, verificar como a mudança na estrutura tributária pode mudar a estrutura de arrecadação no sentido da distribuição dessa receita entre União, Estados e Município." (ANC, 1987, Ata das Reuniões, Supl. 84 p. 50, 26/6/1987, grifo do autor).

Além da descentralização vertical da receita, cujo mérito não encontrou opositor, o constituinte João Agripino (PMDB/PE) destacou a relação entre as transferências e redução das desigualdades ressaltando, portanto, o problema da repartição horizontal de receita. Defendia que o Fundo de Equalização, que seria o substituto dos Fundos de Participação na proposta do IPEA, "não poderia ser diminuído dos níveis atuais" e as transferências deveriam ser automáticas e garantidas constitucionalmente (ANC, 1987, Ata das Reuniões, Supl. 84 p. 56, 26/6/1987). Em seu entender, entretanto, o aumento global de arrecadação dos estados devido à descentralização vertical das receitas seria de $20 \%$, mas sua redistribuição horizontal não mitigaria desigualdades.

"A proposta [de reforma apresentada pelo IPEA] agrava seriamente as disparidades regionais. Do crescimento do bolo das receitas, a região Sudeste fica com $72,4 \%$ na distribuição,[...] a região Norte sofre uma queda de 14,4\% na arrecadação; a região Nordeste tem um acréscimo de 14,3\%." (ANC, 1987, Ata das Reuniões, Supl. 84 p. 55, 26/6/1987b)

Em um primeiro momento nos debates da STPDR, muitos constituintes, como fez João Agripino (PMDB/PE), associavam a redistribuição horizontal da receita pública com a redistribuição da renda. Em resposta a esse comentário, o Prof. Fernando Rezende argumentou que o critério de rateio dos fundos deveria ser alvo de lei complementar. Segundo destacou, o fundo deveria ter por princípio a equalização regional. A dinâmica da 
desigualdade exigiria, portanto, regras que fossem mais facilmente alteradas conforme mudanças socio-demográficas. Assim, critérios de rateio deveriam ser regulados por legislação complementar, mais fácil de ser alterada que a Constituição. Diz ainda que sua equipe do IPEA está "absolutamente de acordo em que há necessidade de transferir, via sistema de repasses federais, uma parcela maior de recursos para o Norte e Nordeste" (ANC, 1987, Ata das Reuniões, Supl. 84 p. 57, 26/6/1987). Sua proposta, porém, era menos redistributiva que outras, como visto na seção anterior.

O Sr. Benito Gama (PFL/BA), que presidia a seção, expressou também sua preocupação com o que chamou de questão regional. Aponta que a "disparidade entre as regiões pobres e ricas deste país é de importância muito grande nesta Comissão e na Constituinte" (ANC, 1987, Ata das Reuniões, Supl. 84 p. 59, 26/6/1987). Seu principal ponto era que não se poderia "deixar de quantificar para identificar quem ganha e quem perde, se a União, os Estados ou os Municípios. [...] Não podemos, diz, [...] correr o risco de decidir uma matéria da mais alta importância, levando ao país uma dúvida com relação aos ganhos e perdas entre estados e regiões" (idem, pg.60). Argumenta que não basta aumentar o número de impostos sob responsabilidade de estados e municípios (descentralização da arrecadação), pois para muitos destes não haveria base econômica que resultasse em ganhos de orçamento pela via da expansão da área de tributação própria das subunidades. Defendeu, então, duas modificações: a descentralização de receita das mãos da União (distribuição vertical) e desconcentração da receita nas mãos dos estados mais ricos (redistribuição horizontal).

O relator Fernando Bezerra Coelho (PMDB/PE) também defendeu esse ponto. Diz que "é preciso, [...], atender esse anseio, que está manifesto em todos os constituintes, que é o desejo de maior autonomia para os estados e municípios" (ANC, 1987, Ata das Reuniões, Supl. 84 p. 60, 26/6/1987). Essa autonomia resumia-se, basicamente, em maiores receitas e sua livre utilização pelo governo respectivo. O relator defendia a descentralização via aumento da área de tributação própria das subunidades, mas priorizava a via da transferência de recursos. O constituinte reconhecia que descentralizar via o primeiro mecanismo poderia significar agravamento das desigualdades. Havia em 
seu discurso uma forte associação entre a distribuição interregional das receitas públicas e a distribuição interregional de renda. Reconhecia também que a redistribuição interregional de receita pública implicava centralização. Diz ele que

\begin{abstract}
"Mas, se formos percorrer um caminho exclusivamente no sentido de atender a essas necessidades [de autonomia de estados e municípios], estaremos deixando o tributo onde ele é gerado. Certamente estaremos, então, desatendendo a outro princípio essencial, que é criar uma federação para vencer os desequilíbrios regionais. É preciso ter em mente que devemos criar mecanismos de compensações, onde a autonomia dos estados possa ser assegurada, [...] mas que, por outro lado, se resguarde um certo nível de centralização na arrecadação do tributo para que através de mecanismos de transferência institucionais possamos praticar uma política de distribuição de rendas, transferindo os recursos gerados nas regiões mais ricas para as regiões mais pobres; que possamos caminhar no sentido de que os mais ricos e os mais bem aquinhoados em termos de patrimônio possam efetivamente contribuir do ponto de vista fiscal de forma mais ampliada do que hoje ocorre no nosso sistema" (ANC, 1987, Ata das Reuniões, Supl. 84 p. 61, 26/6/1987, grifo do autor)
\end{abstract}

O Prof. Alcides Jorge Costa, professor de direito tributário da USP, que também apresentou trabalho na subcomissão, chamou a atenção também para outra dimensão envolvida na autonomia dos entes federativos, ou seja, a autoridade sobre o gasto.

"Estados e municípios devem ter autonomia. Claro, e hoje há um grande movimento para aumentar a autonomia dos estados e dos municípios, o que depende, em grande parte, de terem eles fontes de receita satisfatórias; e que depende, em enorme parte, do fato de terem eles poder de decisão sobre essas fontes de receita porque o problema da centralização [...] resulta não só da maior concentração de arrecadação nas mãos da União [...] mas resulta também de uma enorme concentração de poder decisório da União" (ANC, 1987, Ata das Reuniões, Supl. 84 p. 64, 26/6/1987, grifo do autor).

Do ponto de vista do federalismo fiscal, ao longo das reuniões, foi se consolidando nos debates a definição da repartição da receita como um problema mais claramente 
relacionado com a redistribuição da receita pública em lugar da redistribuição de renda, cuja associação passou para o nível dos pressupostos.

O Prof. Geraldo Ataliba, outro expositor convidado, também professor de direito tributário da USP, tratou do tema da distribuição e repartição de receita, tanto do ponto de vista horizontal quanto vertical. Disse ele que:

"Há município e estados pobres, e o único meio de alcançar o equilíbrio nacional nessa matéria - equilíbrio necessário e desejável - é exatamente a União dispor de uma parcela maior para pode ser o instrumento de tirar o dinheiro da região rica e pôr na pobre, tirar do município rico e dar para o pobre." (ANC, 1987, Ata das Reuniões, Supl. 85, p. 76, 26/06/1987)

O Prof. Geraldo Ataliba comentou o seguinte a respeito da repartição de receita, em especial quanto a uma pergunta adicional, que inquiria sobre a criação de imposto municipal para a prestação, pelo município, de serviços de saúde:

"A criação do imposto municipal tem aspectos interessantes, mas impede exatamente o mecanismo de compensação, cujo embrião está, hoje, nos fundos. Foi razoavelmente equacionado nos projetos do IPEA e Afonso Arinos, que permite que as regiões ricas contribuam para que a União gaste nas regiões pobres, pois se os municípios pobres - são três mil no Brasil tiverem que manter seus serviços de saúde com seus recursos, estes não existirão. Eles existirão apenas nos municípios restantes." ( ANC, 1987, Ata das Reuniões, Supl. 85, p. 84, 26/06/1987)

Como vimos, entretanto, esse equacionamento da desigualdade pela solução proposta pelo IPEA parecia um pouco distante daquelas que os próprios estados mais pobres estavam almejando.

Destacando o nível municipal, o constituinte Osmundo Rebouças (PMDB/CE) ressalta que a "filosofia da nova Constituição" seria a descentralização de funções (ANC, 1987, Ata das Reuniões, Supl. 85, p. 92, 26/06/1987). Destacou também que as propostas avaliadas então na subcomissão "quase invariavelmente apontam um avanço da esfera municipal na receita pública" (ANC, 1987, Ata das Reuniões, Supl. 85, p. 92, 26/06/1987). Defendeu o constituinte que o município deveria aumentar sua participação via 
transferências, pois a via da arrecadação própria poderia ser mais difícil. Defendeu ainda que o município não fosse limitado em sua autonomia para definir impostos e alíquotas, desde que não interferissem na política tributária do país. Mas o constituinte defendeu que a União tivesse o controle último sobre a possibilidade de criação de impostos. A União autorizaria a criação de um imposto municipal e o município decidiria por sua adoção ou não. Osmundo Rebouças defendeu também a não vinculação da receita municipal (ANC, 1987, Ata das Reuniões, Supl. 85, p. 92, 26/06/1987). Ou seja, buscava tanto do ponto de vista da receita quanto da decisão sobre o gasto (autonomia) fortalecer as subunidades.

O constituinte Fernando Bezerra Coelho (PMDB/PE), relator da subcomissão, pediu a palavra para reforçar a tese da descentralização. Disse,

"Há necessidade de vencer esse desafio, qual seja o de propiciar a urgente descentralização administrativa, política e financeira neste País. O caminho aponta verdadeiramente para fortalecermos os municípios e os estados brasileiros" (ANC, 1987, Ata das Reuniões, Supl. 85, p. 94-5, 26/06/1987).

O constituinte ainda ressaltou sua posição favorável à autonomia dos municípios para criar impostos e para produzir sua própria arrecadação e, no que diz respeito às transferências, expressou tanto sua preocupação com os critérios de repartição de receita quanto, claramente, expôs sua posição:

"[Jorge Khoury] relatou-nos as dificuldades que um prefeito do interior do Nordeste brasileiro enfrenta, colocando questões que nos irão desafiar na escolha dos critérios que teremos de adotar para a transferência dos fundos que serão criados, a fim de permitir maior justiça social entre as diferentes regiões brasileiras. Todos constatam que existe disparidade regional muito grande neste Brasil-continente, e é preciso que a política tributária possa também ser instrumento de uma política de equilíbrio, que permita que se tirem recursos das regiões mais ricas e se os aloquem nas regiões mais pobres, para que, ao longo do tempo, possa existir um quadro de equilíbrio dentro da nossa Federação" (ANC, 1987, Ata das Reuniões, Supl. 85, p. 95, 26/06/1987). 
Ainda aqui o discurso dos parlamentares intercambiava entre os termos "redistribuição de receita interregional" e "redistribuição de renda". Encerrando essa reunião, Nion Albernaz (PMDB/GO), que presidia a STPDR no momento, ressaltou que emergia nos debates a posição descentralizadora dos constituintes. Diz ele:

"À medida que o trabalho desta subcomissão se desenvolve, começamos a perceber, como disse o Constituinte Osmundo Rebouças (PMDB/CE), que mais importante que a distribuição de receita tributária de forma equânime é a distribuição de competências, seja competência legislativa, seja competência tributária, seja competência política ou administrativa . Começo a perceber que essa subcomissão desempenhará um papel muito importante. Deverá sugerir a outras comissões que também tentem a descentralização" (ANC, 1987, Ata das Reuniões, Supl. 85, p. 95, 26/06/1987).

Na quinta reunião da STPDR, no período da tarde, houve palestra de dois expositores. O primeiro foi o Sr. Ozias Monteiro Rodrigues, secretário da Fazenda do Estado do Amazonas, que representava os Secretários da Fazenda dos estados do Norte, Nordeste e Centro-Oeste, e Luiz Carlos Hauly Secretário da Fazenda do Paraná, representando os Secretários da Fazenda dos estados do Sul. É importante notar que ocorreram dois encontros em separado no início dos trabalhos da constituinte, estimulados pela subcomissão de Tributos Participação e Distribuição de Receitas, entre os secretários de fazenda dos estados, o chamado encontro de Manaus, com secretários dos estados das regiões Norte, Nordeste e Centro-Oeste, e o encontro de Porto Alegre, com os secretários dos estados das regiões Sul e Sudeste.

O Sr. Ozias Monteiro Rodrigues apontou que a discussão dos estados das regiões Norte, Nordeste e Centro-Oeste se pautou no trabalho do Sr. Fernando Rezende e da equipe do IPEA. Suas propostas, então, resumiam-se a modificações que deveriam ser introduzidas nessa proposta. Em especial, a proposta que emergiu dos secretários de Fazenda dos estados do Norte, Nordeste e Centro-Oeste, conforme aponta o Sr. Ozias Monteiro, procurava garantir que "houvesse compensações e não ocorressem maiores perdas, ou previsões de perdas, para essa ou aquela região" (ANC, 1987, Ata das 
Reuniões, Supl. 85 p.66, 1/5/1987, grifo meu). A proposta procurava não só diminuir as perdas, mas aumentar a descentralização e a redistribuição interregional de rendas públicas. Nesse sentido, havia na proposta e na exposição do Sr. Ozias Monteiro, o reconhecimento de que se falava, antes de mais nada, em redistribuição de receita pública, e não de renda. No que tange à descentralização de receita pública, diz ele:

"O primeiro princípio que levamos em conta é o de que o sistema tributário brasileiro deve apresentar maior equidade, tendo como consequência uma mais justa distribuição das rendas públicas entre União, estados $e$ municípios. Na verdade, hoje é patente, é evidente, é indiscutível o fato de que o sistema se mostra altamente concentrador de rendas em benefício da União, deixando os estados e municípios em situação verdadeiramente difícil [...]" (ANC, 1987, Ata das Reuniões, Supl. 85 p.66, 1/5/1987).

Além da descentralização da receita, a proposta defendia uma maior redistribuição para as regiões mais pobres.

"[...] a preocupação fundamental é de que haja um aumento das receitas dos estados e municípios, beneficiando mais fortemente as áreas mais carentes da Federação" (ANC, 1987, Ata das Reuniões, Supl. 85 p.66, 1/5/1987).

Além disso, a proposta dos secretários da fazenda defendia maior autoridade de gasto e para legislar sobre a área de tributação exclusiva (criar ou modificar alíquotas). Diz:

"Outra premissa básica - e muitas delas, quase todas, coincidem com aquelas consideradas pelo grupo de IPEA - é a necessidade de se propiciar aos estados e municípios maior autonomia fiscal, a fim de que, definida a fatia de recursos que lhes serão disponiveis eles tenham pelo menos, com suas comunidades, a livre iniciativa de escolher suas prioridades para atender às suas populações. Até hoje, não há essa autonomia. Também reivindicamos um pouco mais de autonomia tributária, no que tange à discriminação das competências para os estados" (ANC, 1987, Ata das Reuniões, Supl. 85 p.66, 1/5/1987). 
A proposta dos secretários de fazenda do Norte, Nordeste e Centro-Oeste mantinha praticamente a mesma estrutura anterior. O motivo desta preferência seria evitar custos administrativos envolvidos com a transferência da arrecadação para estados e municípios. Diz:

"[...] da forma como estamos sugerindo, as emendas [ao projeto do IPEA] têm o objetivo de manter a estrutura de administração tributária no Brasil sem nenhuma ou quase nenhuma adaptação, mantendo os mesmos custos, com benefícios maiores, em termos de rendimentos, de recursos arrecadados" (ANC, 1987, Ata das Reuniões, Supl. 85 p.66, 1/5/1987).

Essa proposta era bastante conservadora em comparação com as outras apresentadas, exceto no que diz respeito às transferências interregionais. Porém, se preocuparam, na divisão horizontal das receitas, de não impor custos aos estados do Sul e Sudeste.

"Uma outra questão é o sistema de partilha proposto tanto pela comissão de IPEA quanto por nós, e que beneficia mais os estados menos desenvolvidos, com base no critério de redistribuição de renda aos estados e municípios. Os estados menos desenvolvidos teriam maior ganho sem, no entanto, prejudicar os mais desenvolvidos" (ANC, 1987, Ata das Reuniões, Supl. 85 p.66, 1/5/1987, grifo do autor).

Uma demanda importante dos estados do NO, NE e CO era que a Constituição fixasse as diretrizes de distribuição vertical e redistribuição horizontal de receitas "para que não haja problema posterior quando de sua fixação em leis complementares" (ANC, 1987, Ata das Reuniões, Supl. 85 p.66, 1/5/1987). Eles também propunham que houvesse apenas um fundo de transferência, unificando os existentes. A justificativa era atingir de modo mais eficiente a redistribuição interregional de receitas.

Além da proposta de consagrar os princípios de partilha de receita na Constituição, indicaram sua preferência pela definição dos critérios de rateio da redistribuição horizontal. Segundo a proposta, $5 \%$ deveria ser redistribuído proporcionalmente à área territorial, e 95\% proporcionalmente à receita tributária per capita de cada unidade. Aqui, existe uma modificação importante da legislação anterior. Esta definia que 95\% do FPE 
fosse distribuído por critério inversamente proporcional ao PIB per capita das unidades constituintes, e não à sua receita tributária. Ou seja, a proposta da coalizão dos estados mais pobre modificava o critério de uma receita presumida baseada no PIB para uma receita efetiva. Ao terminar sua exposição, o Sr. Ozias Monteiro Rodrigues reafirmou sua posição:

"Não mexemos em nenhuma região mais desenvolvida, beneficiando as menos desenvolvidas, sem também dar o balanceamento." (ANC, 1987, Ata das Reuniões, Supl. 85 p.68, 1/5/1987).

Em seguida, proferiu palestra o Sr. Luiz Carlos Hauly, Secretário da fazenda do Paraná, representando os estados do Sul. Ele propunha a descentralização dos recursos e da prestação dos serviços, restringindo a União apenas à representação externa, segurança nacional e justiça. Em especial, demandava o aumento da base do principal tributo estadual, ou seja, o ICMS. Diz ele: "sem a ampliação da base do ICMS, não há possibilidade de darmos encaminhamento a qualquer proposta" (ANC, 1987, Ata das Reuniões, Supl. 85 p.69, 1/5/198). De fato, para os estados mais ricos, o ICMS desempenha uma fonte de receita mais importante que as transferências. Isso se reflete nos interesses apresentados pelo expositor na Subcomissão. Ele resume os pontos demandados pelos estados do Sul:

"Restauração e consolidação da principal fonte de recursos para os Estados [, o ICMS] e os Municípios, de modo que estes possam acompanhar o crescimento econômico do País, não dependendo de auxílios federais ou empréstimos; reavaliação dos mecanismos de transferências intergovernamentais de recursos, propiciando às regiões menos desenvolvidas um nível adequado de capacidade de gastos, para evitar as atuais distorções. A partilha deverá ser feita aplicando-se um percentual sobre a receita tributária total da União; redistribuição dos encargos entre os três níveis de governo, objetivando a descentralização." (ANC, 1987, Ata das Reuniões, Supl. 85 p.69, 1/5/1987).

O constituinte João Machado Rollemberg (PFL/SE), que já havia sido secretário da fazenda, destacou a dependência dos estados perante a União. Destacou o parlamentar também a deficiência financeira das subunidades e apontou que: 
"S. EX" se baseou em um documento do IPEA, muito bem elaborado, mas que, na verdade, não representa o pensamento dessa subcomissão" (ANC, 1987, Ata das Reuniões, Supl. 85 p.70, 1/5/1987).

Ou seja, formou-se na Constituinte uma coalizão dos representantes do Norte, Nordeste e Centro-Oeste que defendia a proposta formulada pelos secretários de fazenda de suas respectivas regiões, coalizão esta articulada em torno da preferência pela intensificação da redistribuição interregional de receitas via transferências constitucionais. Em oposição, os constituintes das regiões mais ricas, em especial dos estados do Sul, defendiam posições mais próximas das propostas da FAFITE e do IPEA. Para os representantes do Sul, o Fundo de Ressarcimento para compensar as perdas de receita era a principal demanda. A divergência principal que o parlamentar João Machado Rollemberg ( $\mathrm{PFL} / \mathrm{SE})$ levanta no trecho acima diz respeito diretamente à questão regional. Na proposta do IPEA, a maior parte da descentralização das receitas ocorreria através do incremento no IVA (então ICM) de diversos impostos. Segundo o parlamentar, isso beneficiaria apenas os estados do Sul e Sudeste. O parlamentar apontou que:

"A meu ver, a mudança pura e simples do ICM para IVA é questão de nomenclatura. É preciso estabelecer melhor a partilha da arrecadação. Se estabelecermos critérios de alíquotas que não tenham sido devidamente estudadas, daremos um salto no escuro [...]

Portanto, no meu entender, o importante é a equidade nos percentuais de partilha de receita [...]

Seriam necessários mais dados, fornecidos pelo Governo Federal, pelos governos estaduais e pelos governos municipais, [...] para que pudéssemos estabelecer esses percentuais. Isso porque, por trás disso, está previsto não só um aumento de receita, mas está-se propondo mais uma distribuição de encargos" (ANC, 1987, Ata das Reuniões, Supl. 85 p.70, 1/5/1987).

Osmundo Rebouças (PMDB/CE) argumentou que os critérios de rateio dos Fundos de Participação não deveriam ser fixados na Constituição, mas em lei complementar, arguindo que tais coeficientes demandariam reajustes regulares. Se constassem da constituição, haveria necessidade de emendamentos regulares. Apontou, porém, que 
"O princípio de aumento da participação dos recursos públicos disponíveis é que deve ser consagrado na Constituição, ou seja, o aumento da participação dos estados e municípios no bolo total dos recursos disponiveis. A partir desse princípio, pode-se até fixar o percentual total que os estados e município devem ter vis-à-vis a União no bolo. A partir dessa fixação do percentual global, todas as demais medidas virão como instrumentos na lei complementar" (ANC, 1987, Ata das Reuniões, Supl. 85 p.71, 1/5/1987, grifo do autor).

Às questões levantadas, Ozias Monteiro Rodrigues, representando os secretários da fazenda do NO, NE e CO, respondeu:

"Nossa grande preocupação, vejam bem, é que todos ganhem, mas os estados menos desenvolvidos devem ganhar um pouco mais, para que sejam diminuídas as desigualdade interregionais. Esta é a preocupação. [...] A justificativa fundamental [para os pontos da proposta apresentada] é esta: mais receita para os estados menos desenvolvidos" (ANC, 1987, Ata das Reuniões, Supl. 85 p.71-2, 1/5/1987).

Além disso, o Sr. Ozias Monteiro Rodrigues acrescentou adiante:

"O que achamos é que a proposta [...] pelos técnicos do IPEA, coordenados pelo Dr. Fernando Rezende, se aplicada como está certamente será um salto muito perigoso no escuro. As nossas indicações de alteração, porém, diminuem o risco" (ANC, 1987, Ata das Reuniões, Supl. 85 p.72, 1/5/1987).

Na sequência dos debates, Luiz Carlos Hauly, representante dos estados do Sul, chamou novamente a atenção para a necessidade de simulações para estimar ganhadores e perdedores ou, do contrário, havendo risco de perda de receita para a subunidades, disse que "todo esse esforço, todo esse trabalho, se não redundar num aumento de receita para estados e municípios, será em vão". (ANC, 1987, Ata das Reuniões, Supl. 85 p.72, 1/5/1987). Tal passou a ser o ponto central das barganhas: garantir que a receita aumentasse, mas acima de tudo, garantir que não houvesse perdas ou insegurança quanto a futuras perdas para as subunidades. À medida que os debates prosseguiam e as reuniões se avolumavam, os argumentos se concentravam menos no problema da distribuição de renda e mais nos efeitos das mudanças sobre as receitas públicas em relação ao status quo. Ou seja, a preocupação inicial com a igualdade regional na 
distribuição da renda foi dando lugar à preocupação de quanto cada subunidade perderia ou ganharia no seu orçamento em relação ao status quo, que passava a ser o parâmetro abaixo do qual nenhum constituinte aceitava que fossem fixados os novos coeficientes de partilha.

José Serra (PMDB/SP) destacou o problema adicional de deixar as regras sobre o rateio para momento posterior:

"O segundo ponto, que é fatal [...] é que boa parte das questões ficaria por conta da lei complementar. Hão de perguntar: e se a lei complementar não o fizer? Realmente, tudo pode acontecer, mas é muito difícil, porque segundo proposta que apresentei a Assembleia Nacional Constituinte [...], a nossa comissão e as demais é que se encarregariam de fazer a lei complementar. Se a minha proposta for aceita, continuaremos trabalhando até mesmo na questão da lei complementar. Mas terão de confiar um pouco, senão, não haverá mudança" (ANC, 1987, Ata das Reuniões, Supl. 85 p.72, 1/5/1987).

Na quinta reunião, expôs Cezar Cassel, do Rio Grande do Sul, representando a Federação das Associações dos Fiscais de Tributos Estaduais (FAFITE). Essencialmente, esta proposta se parecia em muitos aspectos à do IPEA, como já discutido. Propunha manter o poder residual nas mãos da União, mas a limitava esta em sua autoridade para conceder qualquer isenção ou imunidade tributária para impostos da área de tributação exclusiva das subunidades. Buscava aumentar a receita das subunidades e, no que tange à distribuição de receitas entre os níveis de governo, o Sr. Cassel disse que:

"entendemos [a questão do federalismo fiscal] não no sentido de criar capacidades de gasto para estados e municípios, mas no de ampliar sua capacidade de gerar recursos próprios" (ANC, 1987, Ata das Reuniões, Supl. 85 p.76, 1/5/1987).

O Sr. Cassel defende um fundo de equalização, mas com ressalvas. Disse ele:

"Estamos prevendo ainda um Fundo de equalização, que, [...] é necessário. Entendemos que somente deve haver cuidado para que atribua basicamente às regiões mais pobres do país um patamar mínimo de receita tributária própria per capita. Achamos que deve existir também um 
coeficiente nessa distribuição que meça outros fatores, como o esforço próprio de arrecadação dos estados e municípios. Fazer simplesmente o inverso da arrecadação própria poderá desestimular as unidades federadas a arrecadar" (ANC, 1987, Ata das Reuniões, Supl. 85 p.77, 1/5/1987).

Expôs sua proposta também o Secretário da Fazenda do Estado de São Paulo, Sr. José Machado de Campos Filho. Ele também trabalhava com base na proposta do IPEA. Defendia a incorporação ao IVA (então ICM) dos impostos cobrados como IPI e a transferência da autoridade sobre este imposto para os estados. O Sr. Machado reafirmou, como todos seus antecessores até ali, a necessidade de fortalecimento dos estados e municípios. Porém, defendia mais enfaticamente a autonomia política, administrativa e financeira das subunidades e a fixação de coeficientes de rateio dos fundos e alíquotas em leis complementares. A descentralização, para ele, deveria vir via aumento da área de tributação exclusiva e aumento da autoridade para regular esses impostos. Diz:

"[...].somos manifestamente contrários à proposta que teria sido apresentada - ou está sendo apresentada - a esta Subcomissão, de se instruírem impostos apenas a nível nacional e cuja distribuição entre os estados e os municípios seria feita apenas através de fundos. No nosso modo de ver, tanto os estados quanto os municípios devem ter competência própria para instituição e arrecadação de tributos, a fim de fortalecer, sem dúvida, sua autonomia política, administrativa e financeira

A grande preocupação que deve existir com a reforma tributária diz respeito à descentralização das atribuições e competências dos estados $e$ municípios. Da mesma forma, para que haja esse fortalecimento, é necessária a descentralização tributária ou seja, como a fixação da competência privativa de estados e municípios para a instituição de tributos" (ANC, 1987, Ata das Reuniões, Supl. 85 p.78, 1/5/1987, grifo do autor).

Sua posição era claramente contrária aos clamores redistributivos expressados até então pela coalizão do NO, NE e CO.

"devemos lembrar que [a redistribuição] não pode ter um cunho paternalista. Não podemos pensar em redistribuição de recursos com o 
intuito apenas de beneficiar os estados que aparentemente são mais pobres em termos de arrecadação e de sua participação nos demais entes públicos. Digo isso porque, porque, por exemplo, São Paulo, que mais arrecada, tem de outro lado, compromissos sociais iguais ou até maiores do que outros estados, inclusive do Nordeste".[...] não se pode, pura e simplesmente, aceitar o argumento de que determinados estados devam ser mais beneficiados com a distribuição do Fundo de Participação dos Municípios por serem mais pobres. Precisamos levar em conta, efetivamente, as condições em que vivem suas populações" (ANC, 1987, Ata das Reuniões, Supl. 85 p.78, 1/5/1987).

Segundo alegava, foram feitas simulações no âmbito da Secretaria da Fazenda do Estado de São Paulo a partir da proposta do IPEA. Ele apontava a necessidade de definição de critérios de rateio por lei complementar, mas expressava igualmente suas preocupações em relação a essas definições:

"Para concluir, eu diria que São Paulo se preocupa com uma reforma tributária que deixe para uma lei complementar as definições sobre os critérios e as alíquotas a serem fixados na cobrança dos tributos ou na distribuição dos Fundos de Participação. [...]

Se houvesse condições de trabalharmos, desde já, com uma precisão em termos de números, de taxas, de alíquotas, de critérios para a distribuição dos Fundos de Participação, seria muito melhor para os estados, porque estaríamos, digamos, discutindo todas as hipóteses às claras, sem estarmos sujeitos a surpresas futuras no momento de elaboração da lei complementar e das leis ordinárias[...] Nossa preocupação decorre do fato de estarmos seriamente interessados em que não se reduza, de forma alguma, a arrecadação de nossos estados." (ANC, 1987, Ata das Reuniões, Supl. 85 p.79, 1/5/1987, grifo do autor).

Um outro crítico da proposta do IPEA que expôs na STPDR foi o Sr. Hugo de Brito Machado, Professor de Direito Tributário da Universidade Federal do Ceará. Segundo ele, essa proposta não colocou como um de seus principais objetivos a redução das desigualdades interregionais. Defendeu que a proposta do IPEA manteria ou agravaria a desigualdade regional. Hugo de Brito Machado se posicionou fortemente contrário à descentralização da arrecadação porque isso não ocasionaria a redistribuição, em especial 
porque municípios e estados com baixa capacidade de arrecadação ficariam sem recursos. Em uma intervenção, o relator Fernando Bezerra Coelho (PMDB/PE) questionou o expositor Hugo de Brito Machado sobre o problema da distribuição de receitas públicas.

\begin{abstract}
"Gostaria de obter alguns esclarecimentos adicionais, sobretudo nas questões que S. Sa coloca, no sentido de que é preciso ter muito cuidado para não se percorrer o caminho da descentralização, que implica o não atendimento da política tributária, enquanto instrumento de redistribuição de rendas, penalizando os Estados menos desenvolvidos e os municípios de bases econômicas mais frágeis
\end{abstract}

Nós, que somos nordestinos, filhos de um Município pobre do Estado de Pernambuco, ficamos efetivamente estarrecidos com as colocações tão fortes feitas pelo Prof. Hugo. Perguntaria então se efetivamente seria incompatível oferecer maior competência tributária aos Estados e aos Municípios sem desatender a essa característica que devemos preservar no Sistema Tributário, no sentido de propiciar uma melhor distribuição das rendas públicas em nosso País" (SF, 1988, ANC - Atas das Reuniões - STPDR, p.140).

Nessa reunião, Mussa Demes (PFL/PI) que a presidia a Subcomissão na reunião disse:

Em relação à forma de partilha do Fundo de Participação dos Estados e dos Municípios, a renda per capita, no meu entender, é a forma mais justa, porque transfere maiores recursos para os que deles mais precisam. $O$ último dado conhecido sobre o assunto, se não estou enganado - talvez o meu amigo Reinaldo possa ajudar-me - é de 1970. Alguns Estados, realmente, tiveram a sua renda per capita muito acrescida nesse período. Para o meu Estado isso não tem importância alguma, porque o Piauí era o mais pobre há duzentos anos, continua sendo hoje e vai continuar talvez por outros duzentos anos. Podem, então, calcular essa renda per capita quantas vezes queiram, porque vai continuar assim, se muita coisa não for mudada ainda pela nossa geração. Há, entretanto, uma proposta que me parece interessante, se a Subcomissão resolver fazer uma modificação. E uma proposição dos secretários de Fazenda do Norte do Nordeste e do Centro-Oeste, a fim de que esse cálculo seja feito de forma inversamente proporcional à receita tributária. Falo isso sem nenhum constrangimento, porque tenho a certeza de que os Estados mais poderosos, os Estados do 
Centro-Sul, não se vão empenhar absolutamente por alguma modificação que possa vir a contribuir com um pouco mais de receita para eles, uma vez que essa receita é insignificante, não representa sequer 0,5\%, por exemplo, da receita tributária do Estado de São Paulo." (SF, 1988, ANC - Atas das Reuniões - STPDR, p.147, grifo do autor)

Em resumo, expositores e constituintes eram todos favoráveis à descentralização das receitas públicas. Havia, entretanto, propostas distintas, que expressavam distintas preferências regionais. A proposta do secretário de fazenda da São Paulo, da FAFITE e do secretário de fazenda do Rio Grande do Sul era de descentralização via aumento da área de tributação própria das subunidades, bem como da autoridade para legislar sobre seus próprios impostos. A proposta do IPEA tendia para essa posição, ou seja, de autonomia e geração de receita própria, que era uma meta a ser perseguida a curto e a longo prazo. Já a proposta dos secretários de fazenda dos estados da região NO, NE e CO, bem como de outros expositores oriundos dessas regiões, defendia a manutenção da centralização da área de tributação própria da União para que esse recurso pudesse ser, então, descentralizado via transferências redistributivas. Essa última posição era também a do relator e do presidente da subcomissão, bem como dos parlamentares dessas regiões na Subcomissão. Assim, se a descentralização e o fortalecimento da receita das subunidades eram consenso, mas a forma que tomaria essa descentralização não era consensual. As propostas colocadas na mesa na STPDR ecoavam a divisão regional dos constituintes, sendo que a garantia de aumento da receita pública a principal preocupação de ambas as coalizões.

Ao final da oitava reunião da Subcomissão, ouvidas várias propostas que expressavam a divisão sobre o tipo de descentralização desejável, Benito Gama ressaltou que na reunião seguinte, a 9a da Subcomissão, os constituintes ouviriam "uma exposição sobre os números da arrecadação tributária no País, entre União, Estados e Municípios" (SF, 1988, ANC - Atas das Reuniões - STPDR, p.166). Conforme apontou, “será uma reunião de discussão da subcomissão com alguns membros da comissão, para podermos avaliar realmente os números da receita tributária hoje existente no País, inclusive com as transferências" (SF, 1988, ANC - Atas das Reuniões - STPDR, p.160). Novamente, o conflito 
pela distribuição (vertical) e redistribuição (horizontal) de receitas públicas, foi equacionado em grande parte tomando como fundamento os impactos esperados na receita das subunidades. Essa informação serviu de pauta para as negociações.

\section{Primeiro anteprojeto da Subcomissão de Tributos, Participação e Distribuição de Receita}

No relatório do primeiro anteprojeto da STPDR, o relator apontou que pretendia manter a estrutura básica do sistema fiscal, mas destacou sua orientação no sentido de descentralizar e redistribuir receitas:

"Reconhece-se a racionalidade intrínseca do sistema, mas, sem feri-la, parece oportuno fortalecer intensamente os Estados e Municípios. A concentração de impostos gerou concentração de recursos, tornando ineficiente a máquina estatal. No momento em que se está convencido da necessidade de descentralização de encargos, é imperativo promover a redistribuição de recursos, contemplando, inclusive, um tratamento diferenciado para os Estados menos desenvolvidos." (SF, 1988, ANC - Atas das Reuniões - STPDR, p.202).

O relator destacou que o anteprojeto apresentado por ele fortalecia a descentralização, entre outras medidas, ao eliminar os impostos únicos e colocá-los na base de tributação do ICM estadual, favorecendo assim a receita dos estados desenvolvidos. Ressaltou que aumentava os fundos de participação e tornava transferências especiais (os $2 \%$ destinados ao NO e NE) constitucionais de modo a protegê-las de qualquer negociação orçamentária. A primeira versão do anteprojeto também determinava que o recurso dos fundos de participação, agora ampliados, fosse destinado exclusivamente aos estados com receita pública per capita menor que a média nacional. Isso excluía alguns estados do Sul e Sudeste da participação no Fundo. A compensação que o anteprojeto propunha para essa perda de receita era a devolução de 5\% do IPI como compensação pela perda de arrecadação devida a isenções fiscais para exportações. Esse seria o Fundo de Ressarcimento (proposta da FAFITE, principal 
reivindicação do Rio Grande do Sul). Nesse caso, essa devolução não tinha nenhum caráter redistributivo, porque todos os estados receberiam proporcionalmente à sua arrecadação. Segundo o relator:

"A providência [de transferir para o estado 5\% do IPI proporcional a sua arrecadação] vise a reforçar as finanças dos Estados mais desenvolvidos, que não mais participarão dos recursos do Fundo de Participação e que são penalizados, em termos de receita tributária, pelas exonerações necessárias à efetiva exportação de produtos para o exterior. Isto está muito claro; ao se vincular o percentual de $5 \%$ ao estabelecimento onde foi gerado este imposto, no caso Imposto Sobre Produtos Industrializados, estaremos atendendo, de forma inequívoca, à manifestação dos Secretários da Fazenda dos Estados do Sul e Sudeste, dos governadores que se pronunciaram, no sentido de que, efetivamente, se possa dar maior espaço para que os Estados desenvolvidos possam aproveitar o seu potencial tributário" (SF, 1988, ANC - Atas das Reuniões - STPDR, p.203).

O relator também destacou a necessidade de mais cálculos para avaliar os efeitos da repartição de receita entre os níveis de governo. E reconheceu que as alíquotas, a serem definidas em lei complementar, desempenharam um papel muito importante no cômputo final do impacto orçamentário das mudanças. Disse ele:

"os critérios que irão presidir o rateio dos fundos de participação de municípios e de estados não serão fixados pela Constituição nem estão fixados. Sê-lo-ão pela lei complementar. Pelo debate, ficou clara a posição dos Srs. Constituintes, no sentido de que os critérios de rateio e fixação de alíquotas fossem responsabilidade da legislação ordinária, da lei complementar. É também preciso deixar claro que iremos fazer uma opção política, no sentido de saber qual a melhor forma de atender a esses reclamos colocados diante desta Subcomissão" (SF, 1988, ANC - Atas das Reuniões - STPDR, p.205).

Os "reclamos" nesse caso, eram descentralizar (verticalmente) e redistribuir (horizontalmente).

O constituinte José Maria Eymael (PDC/SP) levantou direta e claramente o problema da realocação horizontal de receitas que poderia advir das reformas, preocupado com a queda da receita que São Paulo poderia enfrentar. 
"Dentro da equidade tributária que se busca, dentro de um processo de redistribuição de receitas, não há dúvida de que para fazermos com que alguém ganhe, alguém vai ter que perder. A não ser que se aumente brutalmente a carga tributária, não existe equação possível para fazer uma distribuição de receita sem que, de um lado, se perca alguma coisa. Quais são os grandes prejudicados no processo de distribuição de renda [pública] no País, hoje? São os Estados e os municípios. [...] Os Estados, hoje marginalizados do processo de desenvolvimento - e é uma injustiça que já se perpetua há várias décadas, ou há séculos - também têm que ocupar um novo espaço dentro de uma política tributária mais justa. O fenômeno da centralização de receita da União, que foi espancado de forma corajosa por

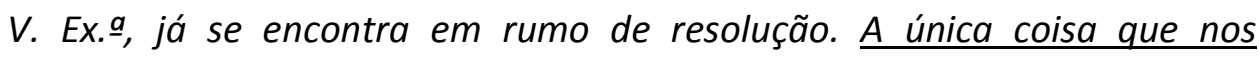
preocupa - e agora falo como Constituinte por São Paulo, porque tenho a obrigação de falar em nome do meu povo, sem perder a visão de Brasil são os Estados produtores, industrializados, que hoje têm uma imensa responsabilidade. Se eles têm uma receita muito alta - e, realmente, temos uma receita tributária muito alta em São Paulo - de um lado, temos uma imensa complexidade sócio-econômica a enfrentar no dia-a-dia e que é crescente. [...] De acordo com os dados de que dispomos em São Paulo, isso vai levar-nos, ao contrário das projeções que foram apresentadas ao companheiro Relator, a uma perda da ordem de 9,6\%, então esse aspecto dos Estados produtores, dentro dessa equação, também tem que ser analisado, talvez até revendo-se os números, para verificarmos de que maneira poderemos evitar essa perda. São Paulo não reivindica aumento na receita tributária. Acho que esse é um ponto importante para deixar registrado, pois reconhecemos que não se pode tudo, ou seja, tirar da União para beneficiar ainda mais os Estados industrializados, porque desse modo acabaremos com todo o processo federativo. Mas parece que seria prudente manter os Estados industrializados com o necessário à sua sobrevivência e alocarmos esses outros recursos para as regiões em desenvolvimento. Nesse sentido, Sr. Relator, se V. Ex. ${ }^{a}$ permitir, vamos solicitar à Secretaria da Fazenda de São Paulo todos os números que estão orientando este nosso pronunciamento e pediremos depois, então, uma reunião com o companheiro Relator, com os técnicos, para que coloquemos todos esses números na mesa e analisemos a realidade concreta" (SF, 1988, ANC - Atas das Reuniões - STPDR, p.210, grifo do autor).

Ao que o relator Fernando Bezerra Coelho (PMDB/PE) respondeu: 
Em relação à partilha dos recursos a nível de regiões, seja no sentido interregional ou interestadual, gostaria apenas de dizer, de forma muito clara, que tive a felicidade de ser assessorado por técnicos das mais variadas procedências, do Rio Grande do Sul, de Santa Catarina, de São Paulo, do Rio de Janeiro, do meu Estado, Pernambuco, da Bahia, do Ceará, enfim, técnicos que participaram no assessoramento do nosso trabalho e que retrataram, na realidade, a diversidade deste imenso País. E eles brigaram com muita veemência quando tivemos que fazer definições, opção na fixação de números, quando as posições estaduais foram afloradas de forma muito clara para que houvesse o equilibrio. Gostaria de dizer que estou absolutamente convencido de que os números expressos nesse anteprojeto ensejam o equilíbrio que esta Subcomissão deseja buscar. Informaria ainda que mantive contato com o Sr. Governador de São Paulo. Até porque, sendo o estado mais rico da Federação, tudo o que for feito no sistema tributário mexe com São Paulo, seja para tirar de São Paulo, seja para dar a São Paulo, quando então manifestamos essa preocupação. Durante todo o processo de discussão e reunião com grupos de técnicos, contamos com a presença de um assessor da Secretaria da Fazenda do Estado de São Paulo." (SF, 1988, ANC - Atas das Reuniões - STPDR, p.210, grifo do autor).

A décima terceira e última reunião da STPDR foi destinada a votar a segunda versão do anteprojeto do relator. Esse segundo anteprojeto incorporava algumas emendas sugeridas pelos constituintes entre a apresentação do primeiro anteprojeto e a apresentação desta segunda versão.

Segundo simulações mencionadas no relatório que acompanhava o anteprojeto, a distribuição vertical da receita ficaria da seguinte forma: a participação da União cairia de $44,9 \%$ para $36 \%$, a dos estados subiria de $37,4 \%$ para $40 \%$, e a dos municípios, de $17,7 \%$ para $24 \%$.

Foram apresentadas um total de 456 emendas. Setenta foram acolhidas por completo, e 52 parcialmente. Praticamente metade, 234 mais precisamente, saíram de um único partido, o PMDB. 
O constituinte José Tinoco (PFL/PE) apresentou uma emenda demandando que a base dos fundos de participação fosse a totalidade dos impostos federais, e não apenas o IPI e o IR. Essa demanda implicava intensificar a descentralização das receitas (SF, 1988, ANC - Atas das Reuniões - STPDR, p.227). A justificativa do relator pela rejeição foi que os outros impostos, como o IOF, não teriam a característica de custear prestação de serviços públicos, mas eram instrumentos de política econômica. Houve apenas um voto contra a rejeição da emenda.

A preocupação dos constituintes com a receita pública das subunidades, mais do que com a preferência por níveis de taxação, foi expressa na emenda apresentada por Aírton Sandoval (PMDB/SP). Sua proposta era no sentido de aumentar a autonomia dos estados na definição de alíquotas do imposto de renda, aproximando-se da proposta do IPEA. Desejava que fosse incluído um parágrafo na constituição autorizando os estados a cobrar um percentual adicional sobre o IR definido pela União. Desnecessário dizer que tal dispositivo interessava mais aos estados mais desenvolvidos. Essa emenda foi aprovada por unanimidade. Novamente: havia consenso sobre a necessidade de aumento da receita pública das subunidades. Mas havia conflito quando à redistribuição horizontal, como pode ser visto no destaque pedido por José Maria Eymael (PDC/SP):

"[...] não se faz uma distribuição de receitas, não se alcançará uma maior justiça social se alguém não ceder. [...] E foi dentro desta ótica que os chamados Estados industrializados compreenderam a absoluta necessidade de adotar outra temática com respeito ao problema da distribuição dos recursos tributários, notadamente à questão pertinente ao Imposto sobre Circulação de Mercadorias, admitindo-se quedas brutais de 9 e 12\% nas vendas para fora do Estado, para uma alíquota, que já se imagina, em consenso, de 5\%. Ao longo do projeto, são diversos os pontos nos quais os chamados Estados industrializados cederam nas suas posições para que aqueles Estados carentes de distribuição tivessem um melhor aquinhoamento. Inclusive, este Constituinte que vos fala, Sr. Presidente, tem o compromisso - que honrará - quando estabelece que o Fundo de Participação dos Estados contemplará aqueles Estados com renda per capita inferior à média nacional. Mas, de outro lado, não podemos ignorar a realidade dos Estados industrializados. Nas projeções que temos de São 
Paulo, como de outros Estados [...] a nova sistemática, segundo dados concretos e não imaginários, representa para essa unidade da Federação uma perda de 9,6\% da sua receita de ICM, o que inviabiliza completamente a nossa existência como Estado. [...] O projeto do Sr. Relator já mitigou essa realidade, estabelecendo que, do produto do Imposto sobre Produtos Industrializados arrecadado em cada Estado, 5\% deste ficarão no Estado arrecadador. E, o que é importante assinalar, sem prejuízo do Fundo de Participação dos Estados, porque esta parcela de 5\% não vai sair do Fundo, sairá diretamente da União. Portanto, não prejudica o rateio. Os dados que temos de todos os Estados que estão perdendo brutalmente com esta redução das alíquotas de ICM nos indicam que para nós a solução desse problema é questão de absoluta sobrevivência. [...]. Portanto, nossa proposta é no sentido de que seja esse índice aumentado de 5 para 10\%, com o que equilibraremos nossas contas." (SF, 1988, ANC - Atas das Reuniões - STPDR, p.223, grifo do autor).

Apesar do argumento que o aumento da arrecadação dos estados não teria devido a transferência do IPI via IR não traria redução do montante destinado ao FPE, a resposta do relator Fernando Bezerra Coelho (PMDB/PE) foi que essa medida mitigaria a redistribuição horizontal da receita. Disse ele:

"Gostaria de alertar que se elevarmos de cinco para dez pontos percentuais, como defende o nobre Constituinte José Maria Eymael, isto significa retirarmos recursos adicionais da União e, consequentemente, diminuir ainda mais os recursos que serão transferidos, via Fundo de Participação, para os Estados do Norte, Nordeste e Centro-Oeste. Para que o equilíbrio pudesse ser buscado, seria necessário ampliar os percentuais, mais uma vez, dos fundos de participação. Portanto, o parecer do Relator é pela manutenção da rejeição, porque isto provocaria um desequilíbrio na distribuição dos ganhos adicionais que se está ensejando para Estados e Municípios." (SF, 1988, ANC - Atas das Reuniões - STPDR, p.223).

Para ser aprovada, a emenda precisaria de 13 votos favoráveis. Não existe registro nominal da votação, mas foram 9 votos contra e 9 a favor, e a emenda foi rejeitada.

Além desse destaque José Maria Eymael (PDC/SP) pediu destaque a outra emenda apresentada que dizia respeito à redistribuição de recursos via um fundo destinado 
exclusivamente às regiões Norte e Nordeste, composto de $2 \%$ do IPI. Disse ele na justificativa de sua emenda:

"[...] o anteprojeto estabelece um fundo especial a ser destinado às Regiões Norte e Nordeste, através de bancos especiais. Não somos contrários à destinação nem à filosofia do processo. Com a alma realmente sangrando, porque não sei como o meu Estado vai enfrentar a perda brutal de receita, ao ter magnanimamente concedido esta equação nacional, sugerimos que se suprima esse fundo especial, que historicamente tem servido apenas a um processo de distribuição de favores políticos, e se distribua esses $2 \%$ previstos da seguinte forma: 1\% para o Fundo dos Estados e 1\% para os municípios. Como o Fundo dos Estados, pela proposta do regimento, que apoiamos, será distribuído apenas para os Estados cuja renda per capita [não mais receita pública] seja inferior à média nacional, os Estados carentes do Norte e Nordeste e, eventualmente, os Estados carentes do Centro-Oeste estariam contemplados. $O$ que não nos parece realmente saudável é inserir-se em uma Constituição, que tende a ser perene, uma norma que apenas distingue, quando a sugestão que fazemos vai alcançar o mesmo objetivo. A distribuição do fundo irá para os Estados, e só os carentes serão atendidos, pois o fundo só irá atingir e contemplar aqueles Estados cuja média per capita seja inferior à média nacional[...]. Então, Sr. Presidente, se podemos alcançar o mesmo objetivo, favorecendo o Norte e o Nordeste e os Estados carentes do Centro-Oeste, sem estabelecer uma discriminação na Constituição, por que fazer o contrário?" (SF, 1988, ANC Atas das Reuniões - STPDR, p.224-5).

Ao que respondeu o relator:

"Se fizermos uma avaliação histórica ao longo dos últimos cinco anos, verificaremos que as aplicações desses recursos do fundo especial eram destinadas às Regiões Norte e Nordeste da seguinte forma: 2/3 para o Nordeste e 1/3 para o Norte. Esses recursos iam de forma negociada, o que evidenciava um clientelismo político, o favorecimento do Presidente a governadores e prefeitos. Estamos, portanto, acabando com isso mas assegurando às Regiões Norte e Nordeste, as mais carentes da Federação brasileira, recursos para a alavancagem do seu desenvolvimento econômico. Esses 2\% que se aloca, segundo o texto constitucional, são de todo necessários para o melhor equilíbrio dos ganhos adicionais, que o 
sistema tributário, como apresentado no anteprojeto, irá acarretar." (SF, 1988, ANC - Atas das Reuniões - STPDR, p.225)

O resultado foi de 14 votos contra 4 e a emenda foi rejeitada. Todos os posicionamentos do relator, contrários ou favoráveis (no caso, um) a emendas, foram acatados pelos membros da Subcomissão. Como expressou Jutahy Magalhães (PMDB/BA), "nem Jesus consegue aprovar suas emendas nessa subcomissão" (SF, 1988, ANC - Atas das Reuniões - STPDR, p.237).

Além das reuniões no Plenário da Subcomissão, ocorreram outras das quais não há registros formais. Benito Gama (PFL/BA), presidente da STPDR, e Mussa Demes (PFL/PI), vice-presidente, participaram em 24/04/1987, no curso dos trabalhos da STPDR, de uma reunião com os Secretários Estaduais da Fazenda e Secretários de Planejamento do Norte, Nordeste e Centro-Oeste, realizada em Manaus. Na segunda-feira seguinte (27/04/1987), haveria um encontro com Secretários de Fazenda do Sul e Sudeste da qual participaria o relator da Comissão do Sistema Tributário, Orçamento e Finanças, José Serra (PMDB/SP).

O QUAdRo 10 - ÁREA DE TRIBUTAÇÃo EXCLUSIVA NAS INSTÂNCIAS DECISÓRIAS DA CONSTITUINTE DE 1988 resume as modificações introduzidas em cada uma das instâncias decisórias da constituinte no que diz respeito à distribuição das áreas de tributação própria. A STPDR modificou pouco os principais impostos que já estavam nas mãos da União. O anteprojeto aprovado na STPDR descentralizou para os estados o IPTR e os impostos únicos, todos incorporados ao ICMS estadual. Além disso, permitia cobrança de adicional sobre o IR e garantia o IRRF. A descentralização da área de tributação própria, evidentemente, beneficia mais a receita dos estados com capacidade de arrecadação.

O QUADRO 11 - TRANSFERÊNCIAS NAS INSTÂNCIAS DECISÓRIAS DA CONSTITUINTE DE 1988 apresenta as modificações introduzidas por cada uma das arenas decisórias da Constituinte com relação às transferências fiscais. O anteprojeto da Subcomissão aumentava de $32 \%$ o montante de recursos destinado ao FPE e ao FPM em relação ao status quo. 
Na dimensão horizontal da distribuição das transferências, o anteprojeto aprovado na STPDR intensificava ainda mais a redistribuição interregional. Ele continha um dispositivo que especificava os critérios de repartição horizontal dos Fundos, destinandoos exclusivamente aos estados com renda per capita inferior à média nacional.

Há uma informação importante que Mussa Demes (PFL/PI) apresentou, por força do debate que travava com Nelson Wedekin (PMDB/SC), a respeito das regras de distribuição dos fundos já na Comissão do Sistema Tributário, Orçamento e Finanças (CSTOF). O anteprojeto aprovado na STPDR destinava o FPE exclusivamente aos estados com renda per capita inferior à média nacional. Porém, no primeiro anteprojeto da STPDR, o texto dizia "receita tributária própria, por habitante" ao invés de "renda per capita". O motivo dessa modificação, que não aparece nos debates da Subcomissão, aparece nos debates da Comissão. Diz Mussa Demes (PFL/PI):

"Há um estudo feito pela assessoria da Comissão, eminente Relator [José Serra (PMDB/SP)], por força do qual, se aprovada a distribuição do Fundo a partir das receitas, na forma como ela foi pactuada, os Estados do Nordeste, ao invés de ganhar, perderão." (SF, 1988, ANC, - Ata das Reuniões - CSTOF, p. 54).

Ou seja, a preocupação com a não redução da receita pública dos estados implicou que o termo receita pública fosse adotado na primeira versão do anteprojeto da STPDR, para regular a distribuição dos recursos do FPE. A mesma preocupação com a receita pública, ou seja, os impactos esperados sobre a receita pública que a regra especificada desse modo acarretaria, fez com que o termo "receita pública" fosse retirado na segunda versão do texto.

Como já argumentado, a preocupação com a redistribuição interregional de renda dominou em certa medida os debates iniciais na STPDR sobre o desenho fiscal, principalmente em relação à partilha da receita pública. Essa preocupação com a redistribuição de renda agrupou os parlamentares em duas coalizões: de um lado, Norte, Nordeste e Centro-Oeste, e de outro, Sul e Sudeste. Ou seja, de um lado os estados mais pobres, de outro os mais ricos. Porém, as simulações que informavam sobre o impacto 
das eventuais alterações no sistema vigente sobre a receita pública das subunidades acabou determinando os rumos das negociações à partir de certo momento, ainda na STPDR, primeira arena decisória sobre o Sistema Fiscal. A partir daí, cada vez mais a preferência por redistribuição interregional de renda tomava a forma, nas barganhas, de realocação de receita pública com vistas a não causar perdas ao orçamento das subunidades em relação ao status quo.

O projeto da STPDR descentralizava a receita, mas de uma forma específica, ou seja, via fundos de participação. Essa modalidade de descentralização da receita foi imposta pela coalizão dos estados do NO, NE e CO, uma vez que o relator, o presidente e a maioria da STPDR pertenciam a essas regiões. A compensação pelas perdas de receita derivadas dos critérios de redistribuição horizontal do FPE impostas aos estados das regiões Sul e Sudeste vinha na forma do Fundo de Ressarcimento (FR), conforme proposto pela FAFITE, no percentual adicional de $5 \%$ que os estados poderiam cobrar sobre o IR federal, bem como na forma do aumento da base do ICM. Entretanto, o anteprojeto final aprovado na STPDR destinava o FPE, principal transferência que promovia a redistribuição interregional, exclusivamente aos estados com renda per capita inferior a média nacional. Isso excluía da distribuição dos fundos os estados de São Paulo, Rio de Janeiro, Santa Catarina, Rio Grande do Sul e Distrito Federal. Os constituintes estavam de posse desta última informação quanto decidiam sobre o sistema fiscal na STPDR e aprovaram seu anteprojeto. 
QUADRO 10 - ÁREA DE TRIBUTAÇÃO EXCLUSIVA NAS INSTÂNCIAS DECISÓRIAS DA CONSTITUINTE DE 1988

\begin{tabular}{|c|c|c|c|c|c|}
\hline & Status Quo & STPDR & CSTOF & CSist (Projeto A) & Constituição 1988 \\
\hline \multirow[t]{7}{*}{ União } & Imp. Renda (IR) & $\underline{I R}$ & $\underline{I R}$ & $\underline{I R}$ & $\underline{I R}$ \\
\hline & Imp. Exp (IE) e Import. (II) & $\underline{\text { IE e II }}$ & $\underline{\text { IE e II }}$ & $\underline{\text { IE e II }}$ & $\underline{\mathrm{II}, \mathrm{IE}}$ \\
\hline & Imp. Op. Financeiras (IOF) & $\underline{\mathrm{IOF}}$ & $\underline{\mathrm{IOF}}$ & $\underline{\mathrm{IOF}}$ & $\underline{\mathrm{IOF}}$ \\
\hline & Imp. Prod. Ind. (IPI) & $\underline{I P I}$ & $\underline{I P I}$ & $\underline{I P I}$ & $\underline{I P I}$ \\
\hline & Impostos Únicos (IUs) & & & & \\
\hline & Imp. Territorial Rural (IPTR) & & & IPTR & IPTR \\
\hline & & & & $\operatorname{IGF}^{(1)}$ & \\
\hline \multirow[t]{7}{*}{ Estados } & ICM & ICMS & ICMS & ICMS & ICMS \\
\hline & IPVA & IPVA & $\underline{\text { IPVA }}$ & $\underline{\text { IPVA }}$ & IPVA \\
\hline & ITBI & ITBI "causa-mortis" & ITBI"causa-mortis" & ITBI"causa-mortis" & ITBI "causa-mortis" \\
\hline & & IRRF & IRRF & IRRF & IRRF \\
\hline & & $5 \%$ sobre IR & $5 \%$ sobre IRPF e IRPJ & $5 \%$ sobre IRPF e IRPJ & $5 \%$ sobre IR \\
\hline & & IPTR & IPTR & & \\
\hline & & ITBI"inter-vivos" & & & $\operatorname{IGC}(4)$ \\
\hline \multirow[t]{5}{*}{ Municípios } & 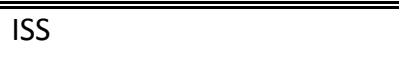 & & & $\mathrm{ISS}^{(3)}$ & ISSQ \\
\hline & $\underline{\text { IPTU }}$ & $\underline{\text { IPTU }}$ & $\underline{\text { IPTU }}$ & $\underline{\text { IPTU }}$ & IPTU \\
\hline & & IVV & IVV & $\operatorname{IVVC}^{(2)}$ & IVVC \\
\hline & & IRRF & IRRF & IRRF & IRRF \\
\hline & & & ITBI "intervivos" & ITBI "intervivos" & ITBI "inter-vivos" \\
\hline
\end{tabular}

\footnotetext{
(1) Imposto sobre grandes fortunas

(2) Imposto sobre venda de combustíveis líquidos e gasosos

(3) base definida em lei complementar

(4) Imp. ganhos suplementares de capital
} 
QUADRO 11 - TRANSFERÊNCIAS NAS INSTÂNCIAS DECISÓRIAS DA CONSTITUINTE DE 1988

\begin{tabular}{|c|c|c|c|c|}
\hline Status Quo & STPDR & CSTOF & CSist (Projeto A) & Constituição 1988 \\
\hline \multicolumn{5}{|c|}{ DA UNIÃO PARA ESTADOS } \\
\hline \multirow[t]{4}{*}{ 14\% IPI e IR (FPE) } & $18,5 \%$ IPI e IR (FPE) & 21,5\% IPI e IR (FPE)(4) & $21,5 \%$ IPI e IR (FPE) ${ }^{(4)}$ & "21,5\% IPI e IR (FPE) \\
\hline & $2 \%$ IPI e IR (FE p/ NO e NE) & $2 \%$ IPI e IR (FE p/ NO e NE) & $3 \%$ IPI e IR (FE p/ NO, NE e CO) & $3 \%$ do IPI e IR (FE) \\
\hline & $5 \%$ IPI $(F R)^{(2)}$ & $10 \% \operatorname{IPI}(\mathrm{FR})^{(1)(2)}$ & $10 \% \operatorname{IPI}(F R)^{(1)(2)}$ & $10 \% \operatorname{IPI}(\mathrm{FR})^{(1)(2)}$ \\
\hline & $30 \%$ de Imp. residual & $50 \%$ imp.residual se excluir estadual & $20 \%$ Im. residual & $20 \%$ imp. residual \\
\hline \multicolumn{5}{|l|}{$50 \%$ IUEE } \\
\hline \multicolumn{5}{|l|}{$70 \%$ IUM } \\
\hline \multicolumn{5}{|l|}{$40 \%$ IUCL } \\
\hline \multicolumn{5}{|l|}{$50 \%$ IT } \\
\hline \multicolumn{5}{|c|}{ DA UNIÃO PARA MUNICIPIOS } \\
\hline \multirow[t]{2}{*}{ 17\% IPI e IR (FPM) } & $22,5 \%$ FPM & $22,5 \% \mathrm{FPM}$ & $22,5 \%$ FPM & 22,5\% IPI e IR (FPM) \\
\hline & $30 \%$ de Imp. residual & & & \\
\hline \multicolumn{5}{|l|}{$10 \%$ IUEE } \\
\hline \multicolumn{5}{|l|}{$10 \%$ IUM } \\
\hline \multicolumn{5}{|l|}{$20 \%$ IT } \\
\hline \multicolumn{5}{|l|}{$10 \%$ IUCL } \\
\hline $100 \%$ IPTR & & & $50 \%$ IPTR & $50 \%$ IPTR \\
\hline
\end{tabular}

Continua... 


\begin{tabular}{|c|c|c|c|c|}
\hline & & TADOS PARA MUNICIPIOS & & \\
\hline $20 \% \mathrm{ICM}$ & $25 \%$ ICMS & $25 \%$ ICMS & $25 \%$ ICMS & $25 \%$ ICMS \\
\hline \multirow[t]{2}{*}{$\underline{50 \% \text { IPVA }}$} & $\underline{50 \% \text { IPVA }}$ & $\underline{50 \% \text { IPVA }}$ & $\underline{50 \% ~ I P V A ~}$ & $\underline{50 \% \text { IPVA }}$ \\
\hline & $50 \%$ IPTR & $50 \%$ IPTR & & \\
\hline \multirow[t]{5}{*}{$50 \%$ ITBI } & $50 \%$ IBTIS & & & \\
\hline & & $50 \%$ do ICMS de cons. final & & \\
\hline & $25 \%$ do FR & $25 \% \mathrm{FR}$ & $25 \% \mathrm{FR}$ & $25 \%$ FR dos estados \\
\hline & $30 \%$ de Imp. residual & & & \\
\hline & & & & $25 \% \mathrm{FE}$ \\
\hline
\end{tabular}

\footnotetext{
(1) O calculo é feito sobre IPI e IR depois de descontado o valor do FPE e FPM e nenhum estado recebe mais de 20\%

(2) Rateio é proporcional à isenção na arrecadação

(3) define rateio somente entre estados com renda per capita inferior a nacional

${ }^{(4)}$ lei complementar deve definir rateio
} 


\subsection{As barganhas legislativas na Comissão do Sistema Tributário, Orçamento e Finanças}

O artigo do anteprojeto aprovado na STPDR que regulava a distribuição horizontal dos Fundos de Participação foi objeto de novas negociações na CSTOF. A proposta de que o FPE fosse destinado exclusivamente para os estados com renda per capita inferior à média nacional motivou a apresentação de emendas pelas bancadas do Sul e do Sudeste. Uma emenda apresentada em massa pelos parlamentes do Rio Grande do Sul buscava eliminar a exclusividade dada pela STPDR na distribuição do FPE aos estados com renda per capita menor que a média nacional. Na justificativa da emenda:

"A União é constituída de 23 Estados. Restringir a participação no FPE apenas às unidades federadas com renda per capita inferior à nacional, na prática, segundo dados da FGV, representa uma discriminação odiosa contra apenas quatro Estados - SP, RJ, SC e RS - e Distrito Federal. Concordamos que os Fundos sejam necessários instrumentos de equalização, porém isso conseguir-se-á através de percentuais diferenciados de partilha, e não mediante injustificadas discriminações não compensadas adequadamente" (emenda de comissão número 500467-5, grifo do autor)

A primeira versão do anteprojeto do relator da CSTOF, José Serra (PMDB/SP), modificava o artigo que destinava o FPE exclusivamente aos estados pobres. Na redação proposta por José Serra, apenas $20 \%$ da receita desse Fundo seria distribuído aos estados com renda per capita inferior à média nacional.

Fernando Bezerra Coelho (PMDB/PE), relator da STPDR, expôs o que entendia ser as principais diferenças entre o anteprojeto aprovado na Subcomissão e o primeiro substitutivo do relator da Comissão, José Serra (PMDB/SP).

"O quarto ponto que assinalo como efetiva abertura de uma janela para uma composição diz respeito aos recursos do Fundo de Participação dos Estados,[...]. Optamos [na STPDR] por transferir maior competência tributária aos Estados da Federação, dando-Ihes maior poder. O Relator José Serra também incorporou a ideia da transferência de seis impostos 
federais, hoje repassados aos Estados brasileiros, sobre produtos que passarão a ser tributados pelo novo imposto estadual, o ICMS - como definiu o Relator José Serra. É evidente que, ampliando seu poder de tributar, estarão ganhando mais aqueles Estados que tenham base econômica mais forte, mais dinâmica. Importante, então, preservar os Estados mais frágeis economicamente na partilha dos recursos globais. [...], seria de todo importante e fundamental que não ocorresse um agravamento no quadro dos desequilíbrios regionais deste País. Por simulações que fizemos [...] Se o Fundo de Participação dos Estados fosse mantido como é hoje, iríamos assistir ao agravamento desses desequilibrios regionais, porque $80 \%$ do ganho dos Estados estaria concentrado nas Regiões Sul e Sudeste do País e apenas $20 \%$ seria destinado às Regiões Norte-Nordeste e Centro-Oeste.

O Constituinte José Serra, ao reincorporar todos os Estados no Fundo de Participação dos Estados, coloca em questão o problema dos desequilíbrios regionais. [...] Mas S. Ex. $\underline{a}$, ao promover essa reintrodução, abriu uma janela, como eu disse no início, para que se pudesse ensejar um consenso, uma composição, uma conciliação de interesses de todos os Estados da Federação, por que contra o critério da exclusividade se levantaram, com muita justiça e com argumentos, os companheiros que aqui representam os Estados da Federação, sobretudo, o Rio Grande e Santa Catarina. Mas é importante não se perder de vista que esses Estados se estão posicionando contra a característica da exclusividade do Fundo, porque hoje estão numa faixa de transição: não são nem tão ricos que sua arrecadação de receita própria Ihes permita bancar a perda da exclusão do fundo, mas também não são tão pobres como os Estados que devem merecer a assistência do fundo. Quero posicionar-me no sentido de estar aberto para encontrarmos um caminho de composição e de conciliação, mas considero insuficiente o percentual estabelecido pelo Constituinte José Serra, ao fixar que apenas 20\% dos recursos do Fundo serão distribuídos exclusivamente aos Estados cuja renda per capita seja inferior à média nacional." (SF, 1988, ANC, - Ata das Reuniões - CSTOF, p. 46)

Os parlamentares estavam orientados pelos dados sobre a receita orçamentária dos estados apresentados tanto pelos secretários de fazenda quando pela proposta do IPEA. Por isso podiam verificar o impacto negativo das alternativas de reforma apresentadas. 
Portanto, no debate sobre a distribuição horizontal da receita fiscal, os parlamentares do Sul e Sudeste, ou mesmo de São Paulo, não estavam barganhando cadeiras, como defendia Souza (1997), nem descentralização de receita via aumento da área de tributação exclusiva e aumento de autoridade fiscal, como defendia Leme (1992), por descentralização via transferências com as regiões pobres. Estavam buscando diminuir as perdas orçamentárias que as mudanças poderiam acarretar, mas acima de tudo buscavam garantir que o nível de receita não diminuísse em relação ao status quo. Ou seja, o conflito horizontal entre os estados na redistribuição interregional das receitas públicas, e não apenas o conflito vertical entre estados e União, desempenhou um papel decisivo na definição do desenho fiscal adotado pela Constituinte.

O relator da Comissão José Serra (PMDB/SP) procurou mitigar a redistribuição interregional e diminuir as perdas dos estados das regiões Sul e Sudeste desde a primeira versão de seu anteprojeto na CSTOF. Neste anteprojeto, eliminou a regra aprovada na STPDR que destinava o FPE exclusivamente para as regiões pobres, que excluía assim São Paulo, Rio de Janeiro, Santa Catarina, Rio Grande do Sul e Distrito Federal da distribuição do Fundo. Na justificativa para a mudança desse artigo dizia que a proposta manteria a distribuição vigente, de modo que as regiões Norte e Nordeste ficariam com mais ou menos $80 \%$ dos recursos do Fundo, uma vez que o cálculo dos coeficientes fosse mantido, e os $20 \%$ exclusivos também.

Irajá Rodrigues (PMDB/RS), que foi ecoado pelo constituinte José Carlos Vasconcelos (PMBD/PE), ressaltou:

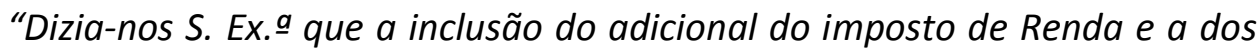
5\% do IPI ocorreram em função da ponderação dos Estados economicamente mais fortes, que queriam uma contrapartida relativamente ao benefício que se estava dando aos Estados economicamente mais fracos, isto e, de receberem integralmente o Fundo de Participação. Noto, de fato, que o Relatar desta Comissão diminuiu em quatro quintas partes a incidência desses benefícios ao Nordeste. Embora tenha dado os benefícios aos Estados favorecidos, em contrapartida não teve a mesma preocupação de reduzi-los também do lado do Estados 
economicamente mais fortes. Já vi que o nobre Relator não entendeu bem, mas vou explicar. De um lado, foi colocado todo o Fundo de Participação para os Estados do Norte - Nordeste, digamos assim, com rendas abaixo da media; de outro lado, foram colocados, então, esses dois dispositivos: $5 \%$ do IPI e o adicional do Imposto de Renda. O Relator retirou quatro quintas partes de um dos pratos da balança, mas se esqueceu de retirar também proporcionalmente do outro prato da balança, razão pela qual eu gostaria de chamar a atenção para o fato que poderá dar a entender que, sendo emenda oriunda de representantes de São Paulo e do Rio de Janeiro, esse esquecimento poderia resultar numa ideia de favorecimento, que, tenho certeza, não foi o objetivo do nosso ilustre Constituinte José Serra. Lembrome que, além desses dois extremos, existem também os Estados intermediários, que, por um lado, se perdem, acabam não ganhando por outro. Ficam em situação lamentável. como é o caso do meu Estado, o Rio Grande do Sul, dos Estados de Santa Catarina, do Paraná e vários outros, que precisam de um tratamento equânime - e não me parece que a Constituinte seja o momento adequado para estratificarmos determinadas posições de hegemonia nacional. Muito ao contrário, é o instante de acabarmos com isso de uma vez por todas." (SF, 1988, ANC, - Ata das Reuniões - CSTOF, p. 49)

Assim, a coalizão dos estados mais pobres reivindicava que a distribuição do FPE fosse mantida conforme definido na STPDR. A modificação introduzida por José Serra (PMDB/SP) reduziu a receita dos estados das regiões mais pobres em relação ao anteprojeto aprovado na Subcomissão. Porém, não reduziu a contrapartida que foi concedida aos estados das regiões mais ricas, no caso, tais contrapartidas eram os $5 \%$ do IPI para o FR e a possibilidade de o estado cobrar um adicional sobre o imposto de renda.

Além desse debate em torno dos critérios de rateio do FPE entre os estados, a coalizão dos estados pobres insistia que o FR poderia resultar em redução no poder redistributivo dos Fundos, pois o FR era também composto por uma porcentagem do IPI, assim como o FPE, e o FR retiraria recursos disponíveis para este último. Mussa Demes (PFL/PI), por exemplo, questiona sobre a origem dos recursos do FR. Nelson Wedekin (PMDB/SC) procura resolver o problema evitando o conflito horizontal: 
"Santa Catarina, por intermédio de alguns de seus parlamentares, apresentará propostas claras nesse sentido. Basicamente -e sabemos que ai há um obstáculo e um impedimento -será uma tentativa de retirar mais um pouco do bolo da União.[...] apenas para que fique absolutamente claro que não é intenção de Santa Catarina, tenho certeza, nem dos Estados do Sul, retirar nada ao Nordeste.." (SF, 1988, ANC, - Ata das Reuniões - CSTOF, p. 54).

Em resumo, as duas coalizões procuravam garantir receita para seus estados e ocorreu um conflito claro em torno da distribuição horizontal da receita.

A nona e última reunião da CSTOF foi destinada à discussão e votação dos artigos do anteprojeto da Comissão, para a qual o relator Jose Serra (PMDB/SP), preparou um novo substitutivo.

A votação deste substitutivo se daria com a votação do substitutivo ressalvadas as emendas e os destaques. Em seguida, ocorreria a votação em globo das emendas ao substitutivo que tiveram parecer contrário do relator. Depois ocorreria a votação dos destaques às emendas apresentadas na CSTOF e, finalmente, votação das emendas apresentadas nas três subcomissões ${ }^{8}$. Na votação do substitutivo do relator, cinquenta constituintes votaram "SIM", e apenas três votaram "NÃO", com uma abstenção. O mesmo resultado ocorreu na votação em globo das emendas com parecer contrário. Isso demonstra que o substitutivo apresentado pelo relator obteve grande consenso na Comissão.

O consenso foi resultado de negociações que ocorreram entre a apresentação do primeiro anteprojeto do relator - que continha as modificações no anteprojeto aprovado na STPDR já destacadas acima em relação à distribuição horizontal dos recursos - e a elaboração deste segundo e último anteprojeto, que foi à votação.

\footnotetext{
${ }^{8}$ Conforme apresentado anteriormente, cada Comissão Temática da Constituinte avaliava o anteprojeto aprovado nas três Subcomissões temáticas que eram responsáveis pelos subtemas da Comissão. Nesse caso, as três subcomissões eram a Subcomissão de Tributos, Participação e Distribuição de Receita (STPDR), a Subcomissão de Orçamento e Fiscalização Financeira e a Subcomissão do Sistema Financeiro. Nesse caso, as emendas apresentadas nas subcomissões quanto da preparação de seu respectivo anteprojeto poderiam ser reavaliadas na Comissão.
} 
Para o primeiro anteprojeto, foram apresentadas mais de 913 emendas. Destas, mais de 490 diziam respeito ao sistema tributário ${ }^{9}$. Dessas últimas, 455 estavam concentradas em sete artigos do substitutivo do relator. Mais precisamente, 200 diziam respeito a um único artigo. Este artigo dizia respeito a um ponto de grande discordância, qual seja, a redistribuição horizontal de receita entre os estados e as regiões. Como aponta o Presidente da CSTOF Francisco Dornelles (PFL/RJ):

"Acredito que, após as negociações realizadas ontem entre o Relator José Serra e os representantes dos Estados do Sul e do Nordeste, houve entendimento. Das 500 emendas apresentadas, 400 estavam concentradas em três artigos. Quanto a isso, também houve entendimento.

Pediria aos Srs. Constituintes que, antes de solicitarem o destaque para as emendas, examinassem o Substitutivo do Relator, porque creio que elas já foram atendidas. Com isso, teríamos condições de reduzir o prazo de votação. Há os assuntos mais polêmicos, e o interesse do Relator José Serra é de que o seu Relatório exprima um certo consenso com relação ao Sistema Tributário, no que se refere à distribuição de receita entre os Estados do Nordeste, com relação às alíquotas únicas, fixadas pelo Senado, e à partilha dos tributos criados com a competência residual, no sentido de haver maior participação dos Municípios na receita tributária. Com relação a esses assuntos e tópicos, creio que os objetivos foram plenamente atingidos." (SF, 1988, ANC, - Ata das Reuniões - CSTOF, p. 74, grifo do autor).

Como já apontado, o primeiro substitutivo do relator Jose Serra (PMDB/SP) destinava $20 \%$ do FPE exclusivamente para estados do NO, NE e CO, modificando o anteprojeto da STPDR que excluía da participação na receita do Fundo os estados de São Paulo, Rio de Janeiro, Santa Catarina, Rio Grande do Sul e Distrito Federal. O status quo, por seu turno, destinava $20 \%$ exclusivamente aos estados do Norte e do Nordeste. 0 primeiro substitutivo não retomava a regra anterior, nem adotava o que havia sido aprovado no anteprojeto da subcomissão.

\footnotetext{
${ }^{9}$ Lembrando que a comissão votava também o anteprojeto sobre o sistema orçamentário e o sistema financeiro.
} 
O novo substitutivo apresentado para votação na Comissão, no entanto, foi elaborado pelo relator José Serra (PMDB/SP) com base nas negociações entre representantes das regiões, motivadas pelas modificações que José Serra introduziu ao anteprojeto da Subcomissão no que dizia respeito à redistribuição interregional da receita pública. Esse novo substitutivo modificou o percentual global do FPE, passando de $18 \%$ para $21,5 \%$.

Houve outra mudança importante. Esse substitutivo alterou outro dispositivo do anteprojeto da STPDR que determinava a distribuição de $5 \%$ da arrecadação do IPI proporcionalmente ao montante arrecadado em cada estado. O novo substitutivo aumentou esse percentual para $10 \%$ que deveriam ser redistribuídos aos estados de modo diretamente proporcional às perdas derivadas de isenções do IPI sobre a exportação de produtos industrializados. O fato é que os representantes dos estados do Nordeste e do Sul, nesse caso em especial Rio Grande do Sul, estavam com os números em mãos. Puderam verificar o impacto de cada detalhe das regras, e estimar com certa precisão os percentuais e as alíquotas que não viessem à prejudicar a receita de nenhum dos estados.

O dispositivo que regulava a repartição do bolo total do FPE, no entanto, foi completamente suprimido. A única regra do substitutivo com relação à redistribuição regional e estadual do Fundo tinha caráter genérico, sem vincular montantes específicos. Dizia o substitutivo que caberia a lei complementar estabelecer as normas de distribuição dos recursos dos Fundos, que seriam distribuídos "com o objetivo de promover equilíbrio socioeconômico entre os estados e entre os municípios" (Art. 23 - II, 3 substitutivo da CSTOF). Esse foi o substitutivo votado ao final pela CSTOF.

Na discussão das emendas ao capítulo tributário propriamente, o Presidente da CSTOF destacou que:

"Gostaria de salientar que o capítulo tributário nada mais é do que um contrato - um contrato entre a União, os Estados e os Municípios - sobre repartição de receita. Portanto, um contrato entre regiões mais e menos favorecidas, sobre repartição de receita entre a União, os estados e os 
municípios - sobre princípios básicos de distribuição de receita." (SF, 1988, ANC, - Ata das Reuniões - CSTOF, p. 132).

Ele propôs uma votação em bloco dos artigos que definiam a competência tributária e a repartição vertical e horizontal de receita. Fez isso porque houve um número enorme de emendas, em especial para o artigo 20 do substitutivo, que definia a partilha de receita via fundos de redistribuição.

"Artigos 17, 18, 19 e 20, que tratam da partilha de receita. Discutimos e conversamos durante todos esses dias intensamente. Participaram dessas conversas os Constituintes e todos os Governadores. Acredito que, em decorrência de toda essa negociação, exista um consenso sobre esses dispositivos. De modo que proporia, para que pudéssemos ganhar tempo e não perdê-lo com apresentação de emendas que não terão acolhida [...]." (SF, 1988, ANC, - Ata das Reuniões - CSTOF, p. 132).

O constituinte José Serra (PMDB/SP), referindo-se especificamente ao fundo de ressarcimento às exportações, apontou que o teto de $20 \%$ para essa transferência acabaria amalgamando nesse fundo características redistributivas.

"Os Constituintes notarão que, no caso dos $10 \%$ do IPI que iriam para os estados exportadores industriais, inserimos uma qualificação, no sentido de que nenhuma unidade federada poderá ter mais do que 20\% desse total.[...] $\mathrm{Na}$ medida em que limitamos a 20\%, aumentamos o bolo disponível na redistribuição para o resto. O Rio Grande do Sul, por exemplo, tem $8 \%$ das exportações industriais no Brasil, e São Paulo mais de 50\%. No momento em que se retira $30 \%$ do bolo que deveria ir para São Paulo, aumenta-se a redistribuição para os estados que têm participação menor, como é o caso da Bahia, Pernambuco, Pará, Ceará, etc. Estamos dando uma característica redistributiva a esse ressarcimento. Trata-se de algo muito importante a ser sublinhado." (SF, 1988, ANC, - Ata das Reuniões - CSTOF, p. 138).

Ou seja, também esse fundo foi negociado tendo em vista seus prováveis efeitos sobre a receita dos estados em relação ao status quo. O teto de $20 \%$ não foi menos porque isso faria com que alguns estados perdessem receita, a exemplo de São Paulo. De outro lado, não foi maior porque diminuiria o bolo dos demais estados. Os percentuais 
foram estabelecidos na medida exata para garantir que estados não recebessem menos do que recebiam sob a vigência da regra anterior, ou seja, no status quo.

Procedeu-se na Comissão à votação simbólica os artigos 13, 15, 16, 17, 18 e 19 e 20 que eram os artigos que tratavam da competência tributária dos entes da federação e da repartição de receitas públicas, juntamente com os Fundos de Participação. Os artigos foram, assim, aprovados.

Em resumo, o anteprojeto final aprovado na CSTOF aumentava os percentuais globais dos Fundos de Participação, de modo a aumentar as transferências para os estados. No que alterava as receitas dos estados mais desenvolvidos, isentava produtos industrializados destinados à exportação da cobrança do IPI e do ICMS. Porém, determinava que a União entregasse $10 \%$ da arrecadação do IPI para os estados, proporcionalmente às perdas decorrentes da isenção das exportações, sendo que nenhuma unidade poderia receber mais de $20 \%$ desse montante sozinha. O anteprojeto também impedia que a União vinculasse o montante transferido à qualquer item do gasto, deixando às subunidades a decisão sobre a aplicação dos recursos. Constitucionalizava o FE para Norte e Nordeste, garantindo sua transferência automática. Da mesma forma, os percentuais globais dos fundos redistributivos seriam garantidos na constituição, bem como o livre uso de seus recursos. O anteprojeto, e a Constituição aprovada, retirava qualquer artigo sobre as regras para distribuição horizontal desses percentuais. 0 anteprojeto apenas definia que uma lei complementar deveria fixar os critérios de rateio.

Durante os debates na Constituinte, como foi mostrado, os representantes estaduais foram crescentemente direcionando suas preocupações para o problema da distribuição de receita pública das subunidades, que em determinado momento passou a ocupar totalmente o lugar dos debates sobre a distribuição de renda. A disputa em torno da distribuição interregional (portanto, horizontal) da receita pública desempenhou um papel decisivo. As barganhas se deram na direção de trocas possíveis para garantir aumento da receita e, acima de tudo, evitar perdas orçamentárias. As regras do jogo são o outro elemento que explica o resultado. 
As regras do jogo e as escolhas da maioria

As decisões da Constituinte sobre o desenho fiscal foram diretamente afetadas pelas regras decisórias por maioria nas arenas decisórias relevantes. Como mostra a TABELA 12 - DISTRIBUIÇÃo REGIONAL E PARTIDÁRIA NA STPDR, a região Nordeste (NE) detinha a maioria dos parlamentares quando comparada às demais regiões, além da presidência (BA) e da relatoria (PE). Somadas, as regiões Norte (NO), Nordeste (NE) e CentroOeste(CO) tinham a maioria na Subcomissão, com $52,1 \%$ dos constituintes. Excluindo a região Centro-Oeste, NO e NE somavam juntos apenas $47,8 \%$ das cadeiras.

TABELA 12 - DISTRIBUIÇÃO REGIONAL E PARTIDÁRIA NA STPDR

\begin{tabular}{lcccccc}
\hline \hline & CO & NE & NO & SE & SU & TOTAL(\%) \\
\hline \hline PMDB & 1 & 3 & 2 & 3 & 3 & 52,2 \\
PFL & 0 & 3 & 0 & 1 & 0 & 17,4 \\
PDS & 0 & 2 & 0 & 0 & 0 & 8,7 \\
PDC & 0 & 0 & 0 & 1 & 0 & 4,35 \\
PDT & 0 & 0 & 0 & 1 & 0 & 4,35 \\
PL & 0 & 0 & 0 & 1 & 0 & 4,35 \\
PT & 0 & 0 & 0 & 1 & 0 & 4,35 \\
PTB & 0 & 1 & 0 & 0 & 0 & 4,35 \\
\hline \hline TOTAL(\%) & 4,35 & 39,1 & 8,7 & 34,8 & 13 & 100 \\
\hline \hline
\end{tabular}

Fonte: Banco de dados ANC, Cebrap.

A CSTOF apresentava configuração semelhante no que diz respeito ao número percentual de cadeiras das regiões. Em compensação, seu presidente era Francisco Dornelles (PFL/RJ) e relator José Serra (PMDB/SP), ambos da região Sudeste. Como mostra a TABELA 13 - Distribuição RegIONAL e PARTIDÁRIA dA CSTOF, somadas, as regiões Norte (NO), Nordeste (NE) e Centro-Oeste (CO) tinham a maioria na Comissão, com 50,8\% dos constituintes. Excluindo a região Centro-Oeste, NO e NE somavam apenas 47,5\% das cadeiras da Comissão. 
TABELA 13 - DISTRIBUIÇÃO REGIONAL E PARTIDÁRIA DA CSTOF

\begin{tabular}{lcccccc}
\hline \hline & CO & \multicolumn{1}{l}{ NE } & \multicolumn{1}{c}{ NO } & \multicolumn{1}{l}{ SE } & SU & TOTAL(\%) \\
\hline \hline PMDB & 2 & 9 & 5 & 8 & 9 & 54,1 \\
PFL & 0 & 11 & 0 & 3 & 1 & 24,6 \\
PDS & 0 & 3 & 0 & 0 & 1 & 6,56 \\
PDT & 0 & 0 & 0 & 2 & 1 & 4,92 \\
PT & 0 & 0 & 0 & 2 & 0 & 3,28 \\
PTB & 0 & 1 & 0 & 1 & 0 & 3,28 \\
PDC & 0 & 0 & 0 & 1 & 0 & 1,64 \\
PL & 0 & 0 & 0 & 1 & 0 & 1,64 \\
\hline \hline TOTAL(\%) & 3,28 & 39,3 & 8,2 & 29,5 & 19,7 & 100 \\
\hline \hline
\end{tabular}

Fonte: Banco de dados ANC, Cebrap.

Na Comissão de Sistematização foi a única instância em que a maioria pertencia às regiões Sul e Sudeste, como mostra a TABELA 14 - DISTRIBUIÇão REGIONAL E PARTIDÁRIA NA Comissão de SistematizaÇão. Somadas essas duas regiões tinham 50,9\% das cadeiras. Em termos percentuais, essa configuração estava muito próxima daquela apresentada na CSTOF na TABELA 13 - DISTRIBUICCÃo REgIONAL E PARTIDÁRIA DA CSTOF. Entretanto, os acordos sobre o sistema fiscal já estavam selados. Nenhuma alteração ou debate substantivo ocorreu nessa instância que mudasse o que foi definido na CSTOF.

TABELA 14 - DISTRIBUIÇÃO REGIONAL E PARTIDÁRIA NA COMISSÃO DE SISTEMATIZAÇÃO

\begin{tabular}{lcccccr}
\hline \hline & CO & NE & NO & SE & SU & TOTAL(\%) \\
\hline \hline PMDB & 6 & 28 & 4 & 31 & 14 & 46,9 \\
PFL & 4 & 24 & 5 & 10 & 4 & 26,6 \\
PDT & 0 & 0 & 1 & 9 & 4 & 7,9 \\
PDS & 0 & 2 & 2 & 1 & 4 & 5,1 \\
PTB & 0 & 0 & 1 & 4 & 0 & 2,8 \\
PDC & 2 & 0 & 0 & 2 & 0 & 2,3 \\
PCB & 1 & 2 & 0 & 0 & 0 & 1,7 \\
PCDOB & 1 & 2 & 0 & 0 & 0 & 1,7 \\
PL & 0 & 0 & 0 & 3 & 0 & 1,7 \\
PT & 0 & 0 & 0 & 3 & 0 & 1,7 \\
PSB & 0 & 0 & 1 & 1 & 0 & 1,1 \\
\hline TOTAL(\%) & 7,9 & 33,3 & 7,9 & 36,2 & 14,7 & 100,0 \\
\hline \hline
\end{tabular}

Fonte: Banco de dados ANC, Cebrap. 
A distribuição regional das cadeiras se repetia, mais uma vez, em Plenário. Como mostra o TABela 15 - Distribuição RegIonal e PARTIDÁria do PLENÁRIO dA ANC de 1988 , somadas, as regiões Norte (NO), Nordeste (NE) e Centro-Oeste(CO) tinham a maioria nessa instância, com 52,31\% dos constituintes. Excluindo a região Centro-Oeste, NO e NE somavam apenas $42,6 \%$ das cadeiras no Plenário.

TABELA 15 - DISTRIBUIÇÃo REGIONAL E PARTIDÁRIA DO PLENÁRIO DA ANC DE 1988

\begin{tabular}{lcccccc}
\hline \hline & CO & NE & NO & SE & SU & TOTAL(\%) \\
\hline \hline PMDB & 37 & 89 & 37 & 100 & 61 & 55,2 \\
PFL & 10 & 73 & 16 & 26 & 13 & 23,5 \\
PDS & 2 & 15 & 5 & 8 & 9 & 6,64 \\
PDT & 1 & 1 & 2 & 16 & 6 & 4,43 \\
PTB & 1 & 2 & 2 & 12 & 0 & 2,9 \\
PT & 0 & 0 & 0 & 14 & 2 & 2,73 \\
PL & 0 & 0 & 0 & 8 & 0 & 1,36 \\
PDC & 4 & 0 & 0 & 2 & 0 & 1,02 \\
PCDOB & 1 & 3 & 0 & 1 & 0 & 0,852 \\
PCB & 1 & 2 & 0 & 0 & 0 & 0,511 \\
SPART & 0 & 2 & 0 & 1 & 0 & 0,511 \\
PSB & 0 & 0 & 1 & 1 & 0 & 0,341 \\
\hline \hline TOTAL(\%) & 9,71 & 31,9 & 10,7 & 32,2 & 15,5 & 100 \\
\hline \hline
\end{tabular}

Fonte: Banco de dados ANC, Cebrap.

Por isso, como mostra a FIgURA 2 - IMPACTO NA RECEITA ESTADUAL ESTIMADA DAS PROPOSTAS APRESENTADAS NA STPDR EM RELACC̃̃o AO STATUS QUO, O resultado final se aproximou da proposta dos secretários de fazenda do Norte, Nordeste e Centro-Oeste, que era a proposta que mais beneficiava a coalizão do Norte, Nordeste e Centro-Oeste na constituinte, pois transferia mais receita para seus estados. Parlamentares dos estados dessas regiões eram maioria em todas as instâncias relevantes, exceto na Comissão de Sistematização, quando os acordos já haviam sido selados. Incluir o Centro-Oeste na repartição do bolo exclusivo do FPE foi uma opção estratégica que, acima de tudo, garantia maioria à coalizão liderada pelas regiões Norte e Nordeste, como se pode ver na 
informação resumida no GráfICo 4 - DISTRIBUIÇÃo REGIONAL NAS ARENAS DECISÓRIAS DA

CONSTITUINTE. As barganhas possíveis foram ditadas por parlamentares dessas regiões.

\section{GRÁFICO 4 - DISTRIBUIÇÃO REGIONAL NAS ARENAS DECISÓRIAS DA CONSTITUINTE}

\begin{tabular}{|c|c|c|c|c|c|}
\hline Plenario & $10,70 \%$ & $31,90 \%$ & $9,71 \%$ & $32,20 \%$ & $15,50 \%$ \\
\hline CSist & $8 \%$ & $33 \%$ & $8 \%$ & $36 \%$ & $15 \%$ \\
\hline CSTOF & $8,20 \%$ & $39,30 \%$ & $3,28 \%$ & $29,50 \%$ & $19,70 \%$ \\
\hline STPDR & $8,70 \%$ & $39,10 \%$ & $4,35 \%$ & $34,80 \%$ & $13 \%$ \\
\hline & $\%$ & $25 \%$ & $50 \%$ & $75 \%$ & $100 \%$ \\
\hline
\end{tabular}

Numericamente falando, sob essas regras, as regiões Sul e Sudeste não teriam de forma alguma cadeiras suficientes para aprovar uma regra que implicasse perdas para as regiões do Norte, Nordeste e Centro-Oeste. O contrário era, e foi possível, como ocorreu no anteprojeto da STPDR. Os estados das regiões Norte, Nordeste e Centro-Oeste, nesse tópico, podiam escolher entre impor ou não perdas aos estados ricos. Podiam ganhar mais ou ganhar menos. Perder receita, para eles, não era opção. Não precisavam, portanto, fazer concessões.

Falta, assim, explicar porque a coalizão majoritária aceitou a eliminação da regra de repartição horizontal do FPE, que destinava esse fundo exclusivamente para os estados com renda per capita inferior à média nacional, como havia sido aprovada na CSTOF. A aceitação dessa modificação pelos parlamentares da coalizão majoritária do Norte, Nordeste e Centro-Oeste na Comissão requer que se admita que, de alguma forma, a regra alternativa também os beneficiaria. A explicação de que esse benefício se resume à obtenção de apoio da minoria para aumentar os percentuais globais a serem destinados ao Fundo, tal como sugere Leme (1992), não é inteiramente convincente, pois as regiões 
pobres tinham maioria de votos em qualquer uma das arenas decisórias, e poderiam aprovar sozinhas este aumento percentual, sem apoio da minoria.

A explicação para a aceitação dessa modificação é o vínculo partidário dos constituintes. Como mencionado no início, a distribuição dos membros das comissões deu-se via negociações dentro dos partidos. Do ponto de vista partidário, um único partido, o PMDB, detinha a maioria em todas as instâncias decisórias, exceto novamente na Comissão de Sistematização. Dentre os parlamentares desse partido, metade pertencia às regiões NO, NE e CO juntas, e a outra metade pertencia às regiões Sul (SU) e Sudeste (SE) na STPDR. A mesma composição se repetia nas outras instâncias com poucas variações. Veja GrÁfICo 5 - PORCENTAGEM DE CADEIRAS DO PMDB POR REGIÕES.

\section{GRÁFICO 5 - PORCENTAGEM DE CADEIRAS DO PMDB POR REGIÕES}

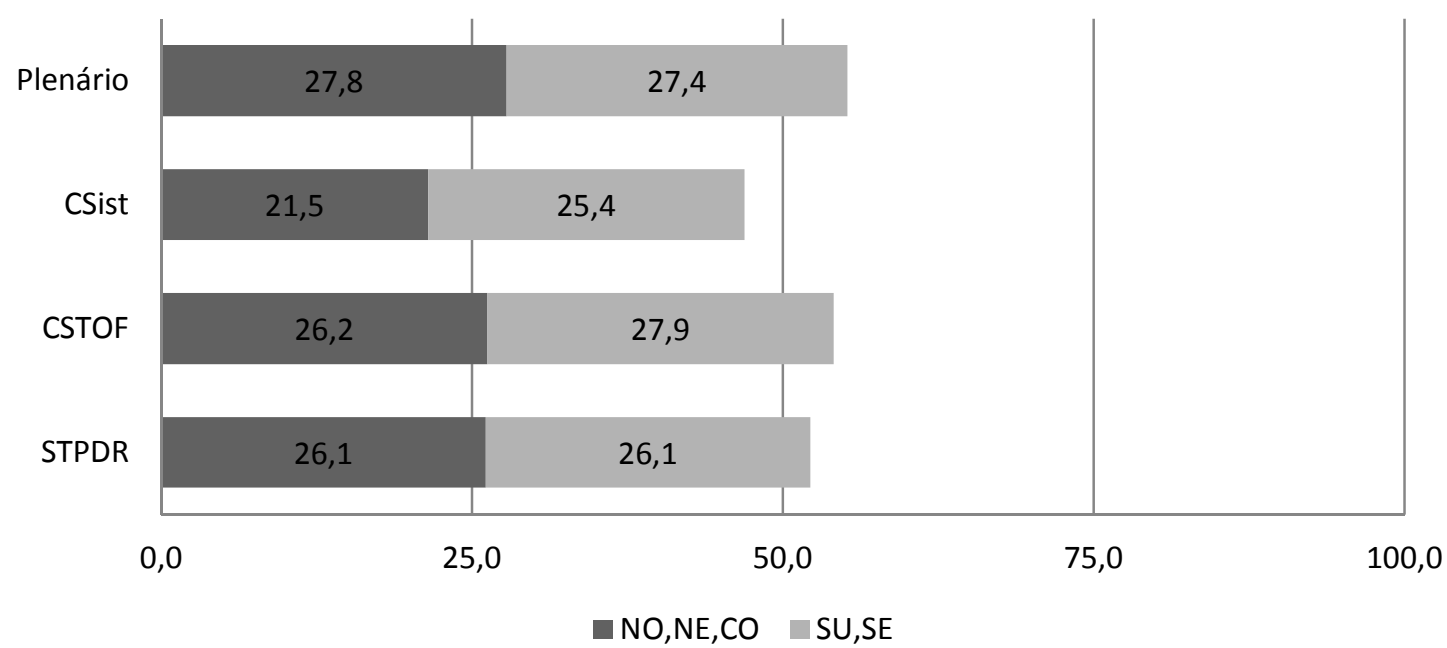

Ou seja, se os constituintes do NO, NE e CO do PMDB adotassem um sistema fiscal que implicasse perdas de receita para os estados das outras regiões, poderiam estar punido eleitoralmente metade de seu partido.

O mesmo quadro se repete se considerarmos os dois maiores partidos (PMDB e PFL) que detinham juntos $69,7 \%$ das cadeiras na STPDR. Dessas cadeiras, mais da metade era de constituintes oriundos das regiões Norte, Nordeste e Centro-Oeste. Veja GRÁFIco 6 - PORCENTAGEM DE CADEIRAS DO PMDB E PFL (SOMADOS) POR REgIÕES. 


\section{GRÁFICO 6 - PORCENTAGEM DE CADEIRAS DO PMDB E PFL (SOMADOS) POR REGIÕES}

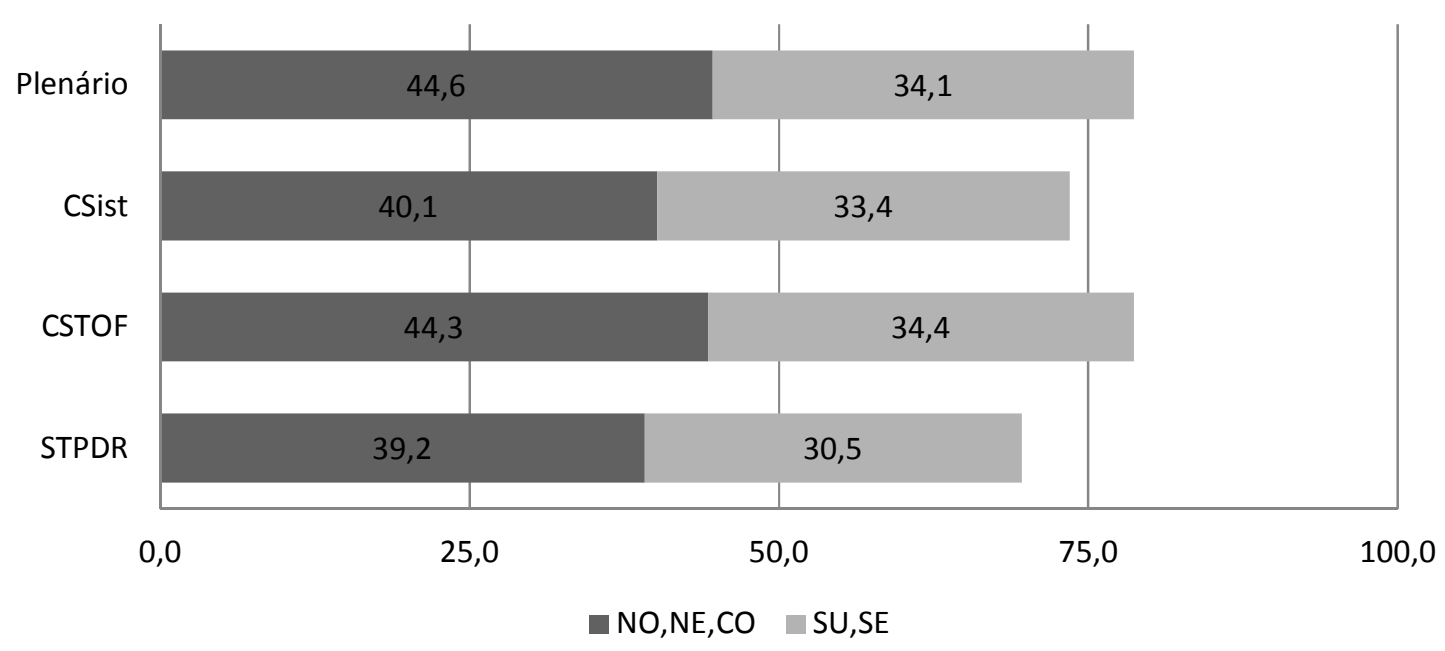

Ou seja, os dois grandes partidos poderiam estar comprometendo eleitoralmente metade de seu partido. As explicações disponíveis para as barganhas que ocorreram na definição do desenho fiscal ignoraram o custo eleitoral para o partido caso se adotasse um desenho fiscal que beneficiasse exclusivamente a coalizão regional majoritária.

O vinculo partidário fornecia o incentivo para que os representantes do grupo majoritário negociassem com os representantes da coalizão minoritária. O contrafactual é muito simples: caso os partidos fossem totalmente descentralizados e a assembleia fosse composta de partidos exclusivamente estaduais, ou mesmo regionais, esses incentivos não estariam presentes. A coalizão minoritária não ofereceu nada em troca das concessões realizadas para seus estados, em especial quando na CSTOF foi retirado o artigo que conferia aos estados pobres, maioria na constituinte, a exclusividade da destinação do FPE. Se a coalizão majoritária mantivesse as perdas impostas à minoria, o único custo que os representantes destes estados enfrentariam seria que companheiros do mesmo partido poderiam ser punidos eleitoralmente em seus respectivos estados. A solução ótima, portanto foi reduzir também esse custo. A solução ótima foi diminuir qualquer custo imposto por um duplo pertencimento, ou seja, o partidário e o regional/estadual. Por isso, a solução para a retirada do artigo que regulava a redistribuição horizontal foi resolvida aumentando os percentuais globais do fundo. Essa 
modificação não ocorreu devido a uma troca de apoio entre as regiões, como defende Leme (1992), ou troca de cadeiras por transferências, como defende Souza (1996). Isso ocorreu porque a solução encontrada minimizava os potenciais custos eleitorais dos constituintes, custos estes impostos por esse duplo pertencimento.

\section{A lei $n^{\circ} 62$ de 1989: a partilha regional e estadual do FPE}

Para finalizar, resta examinar a aprovação da lei complementar no 62/89. Essa lei regulava o critério de rateio do FPE entre os estados. Faltava somente a definição desse critério de rateio para que perdedores e vencedores ficassem de uma vez por todas definidos. Essa lei foi aprovada pelos mesmos representantes da Constituinte, que continuavam seus mandatos como parlamentares.

Os critérios de rateio entre os estados e regiões do projeto de Lei 104/89, aprovado como Lei Complementar 62/89, entregavam 85\% do montante global do FPE exclusivamente aos estados do Norte, Nordeste e Centro-Oeste, e não mais os $20 \%$ exclusivos somados ao rateio geral dos outros $80 \%$, conforme legislação anterior (Código Tributário Nacional (Lei no 5172/66), Decreto-Lei no 1.434 de 1975 e Decreto-lei $1.723 / 79)$.

Como os percentuais globais da descentralização via transferência estavam aprovados, os representantes puderam considerar com precisão o impacto que as mudanças e a repartição horizontal teriam nas receitas dos estados.

Os critérios de rateio do FPE da lei no104/1989 foram cuidadosamente elaborados anteriormente à tramitação do projeto de lei, que advém de uma proposta apresentada na verdade pelos Secretários de Fazenda e Finanças dos Estados e do Distrito Federal (DCD, 31/10/89, p. 12715, Col.01).

Os encontros entre os Secretários estaduais, que ocorreram entre outubro de 1988 e fevereiro de 1989, no qual concordaram "todos os participantes, tanto dos estados mais desenvolvidos quanto menos desenvolvidos", foi que deveria "ser aumentada de 78\% para 
85\% a participação dos estados do Norte, Nordeste e Centro-Oeste no FPE" (idem). Tal medida compensaria esses estados, já que "a ampliação da base de incidência do ICMS [dada pela reforma tributária da constituição beneficiaria] [...] mais fortemente os estados mais desenvolvidos do país" (ibidem). Além da aceitação desse aumento para 85\% do FPE a ser distribuído exclusivamente para as regiões menos desenvolvidas, Firmo de Castro (PMDB/CE) aponta que houve aceitação unânime entre os Secretários da Fazenda e de Finanças dos Estados para a fixação dos coeficientes individuais de cada estado. Os coeficientes individuais dessa lei foram obtidos a partir de ajustes nos coeficientes em vigor. Visavam também compensar o orçamento das regiões mais pobres. Já sabemos, contudo, que havendo aceitação unanime ou não, os parlamentares do Norte, Nordeste e Centro-Oeste teriam condições de aprovar sozinhos esta lei.

A aprovação dessa lei era a culminação dos acordos travados na definição do capítulo fiscal na constituinte, em especial na CSTOF. Como Samuels (2003) aponta, transcrevendo a entrevista com o Clóvis Panzarini, economista paulista que estava no grupo que negociou e definiu o projeto de lei número 104/1989:

"When we had the meeting to define the criteria, the representatives of the Northeast came with a proposal in hand: 'the states from the North, Northest and Center-West shall receive $85 \%$, and the states from the South and Southeast shall receive 15\%. São Paulo will receive 1\% of the total'. And so I asked: 'What is the criteria for decision?' 'Criteria?', they said.'There is none.' I said: 'You are going to cut our share by $75 \%$ whitout any reason?' 'Yes', they said. 'And if you complaint you will get zero.' So I said ' $h$, Ok, one percent is good, great, that's fine."' (Samuels, 2003, p.173).

Os estados das regiões pobres garantiram, assim sua parcela majoritária no FPE, conforme inicialmente haviam projetado. Os coeficientes, no balanço geral, foram obtidos de tal forma que, computadas a distribuição dos fundos de transferência (FR + FPE) para os estados, nenhum deles saísse perdendo em relação ao status quo. O QUADRo 16 PARTICIPAÇ̃̃o dOS ESTAdos NA ARRECADAÇÃo do IPI E IR mostra os percentuais destinados a cada estado antes e depois das modificações introduzidas pela Constituição e pela lei complementar no 62/89. Os estados de São Paulo e Rio de Janeiro, que aparentemente 
perderiam se considerássemos somente os critérios do FPE, foram tranquilamente compensados pela transferência do FR.

Vamos considerar as contas de São Paulo e Rio de Janeiro, aparentemente os perdedores com a nova Lei no 62 de 1989. Pela regra em vigor às vésperas da Constituinte14\% da arrecadação do IPI e IR iam para o FPE, e destes 14\%, 20\% eram destinados exclusivamente aos estados do Norte e Nordeste, restando $80 \%$ para todos os estados. Cada estado, por sua vez, recebia um percentual de acordo com um coeficiente de rateio (veja detalhes no anexo). Ou seja:

$$
F P E_{U F}=0,14 * 0,8 *(I P I+I R) * \operatorname{coef}_{U F}
$$

Considerando a média dos coeficientes de São Paulo entre 1981 e $1990^{10}$, temos o seguinte (ver QUADRO 16 - PARTICIPAÇÃo dos ESTADOS NA ARRECADAČ̃̃o dO IPI E IR (FPE), que apresenta os valores percentuais):

$$
F P E_{S P}=0,0039836 * I P I+0,0039836 * I R
$$

Com a nova regra do FPE, São Paulo passou a ter uma participação de

$$
F P E_{S P}=0,00215 * I P I+0,00215 * I R
$$

Portanto,

$$
\Delta F P E_{S P}=-0,001834 * I P I-0,001834 * I R
$$

Ou seja, se considerarmos somente as transferências do FPE, São Paulo teria uma diminuição correspondente a $0,18 \%$ do IPI e do IR em relação à média anterior. Porém, se consideramos o Fundo de Ressarcimento instituído pela Constituição de 1988, o cenário

\footnotetext{
${ }^{10}$ Foram considerados os anos de 1981, 1984, 1985, 1987, 1989 e 1990, para os quais havia valores oficiais. Dados disponíveis em http://portal2.tcu.gov.br/portal/page/portal/TCU/comunidades/transferencias/fpe fpm. Último acesso em abril/2013.
} 
muda. O coeficiente de 1990 para São Paulo, calculado pelo $\mathrm{TCU}^{11}$, foi de que $20 \%$ do total dos $10 \%$ do IPI que comporiam o FR iria para São Paulo. Portanto,

$$
\begin{gathered}
F R_{S P}=0,02 * I P I \\
\Delta \operatorname{Tranf}_{S P}=\Delta F P E_{S P}+\mathrm{FR}_{S P}=0,01826 * \mathrm{IPI}-0,00183 * \mathrm{IR}
\end{gathered}
$$

Ou seja, São Paulo passou a receber o equivalente a $0,18 \%$ a menos de IR, mas passou a receber o equivalente a 1,8\% a mais de IPI. Para que são Paulo perdesse receita, teríamos que satisfazer a seguinte condição:

$$
\begin{gathered}
\Delta \operatorname{Tranf}_{S P}<0 \\
0,01826 * \mathrm{IPI}-0,00183 * \mathrm{IR}<0 \\
0,01826 * \mathrm{IPI}<0,00183 * \mathrm{IR} \\
\frac{0,01826}{0,00183} * \mathrm{IPI}<I R \\
9,9075 * \mathrm{IPI}<I R
\end{gathered}
$$

Ou seja, para São Paulo perder receita, o IR deveria ser dez vezes maior que o IPI. Para se ter uma ideia, entre 1980 e 1990, a arrecadação do IPI representava em média $58,21 \%$ do que era arrecadado em IR, ou seja, o IR era pouco mais que o dobro. Em 2000, esse percentual atingiu $36,5 \%$, ou seja, o IR era em torno de 2,8 maior. E mesmo assim, a receita dos estados foi acrescida pela ampliação do ICMS, que teve incorporado em sua base os impostos únicos. Segundo dados do IPEA ${ }^{12}$, entre 1974 e 2009 o maior valor arrecadado do IR em relação ao IPI ocorreu em 2009, quando o IR superou o IPI em pouco mais de 6,25 vezes. Em todos os outros anos, o IR não chegou a ser 4 vezes maior. A

\footnotetext{
${ }^{11}$ Resolução no 244/1990, disponível em http://portal2.tcu.gov.br/portal/page/portal/TCU/comunidades/transferencias/fpe_fpm. Último acesso em $16 / 09 / 2012$.

${ }^{12}$ Disponíveis em http://www.ipeadata.gov.br/. Último acesso em abril/2013.
} 
média entre 1974 e 2009 é de um IR 2,3 vezes maior que o IPI, com um desvio padrão de 1,18 .

Se fizermos os mesmos cálculos para o Rio de Janeiro, é possível verificar que para o ano de 1990, o Rio de Janeiro aumentou sua participação no IPI em aproximadamente $0,75 \%$, mas diminuiu no IR em $0,13 \%$ em relação à média dos anos anteriores. Para que essa variação represente perda de receita, a arrecadação do IR deveria ser 6 vezes maior que a do IPI.

Em suma, esses estados não perderam receita por causa das novas definições das transferências federais. Ao contrário, ganharam receita via transferências, e ainda mais via ampliação da área de tributação própria. Os critérios de rateio do FPE, apesar de serem regulados em lei complementar, foram aprovados por votação simbólica, com apoio das lideranças dos diversos partidos, sem que qualquer emenda ou debate substantivo ocorresse durante sua tramitação.

QUADRO 16 - PARTICIPAÇÃO DOS ESTADOS NA ARRECADAÇÃO DO IPI E IR (FPE)

\begin{tabular}{lcccccc}
\hline \hline UF & Região & $(\mathbf{A})$ & $(\mathbf{B})$ & $(\mathbf{C})$ & (C) - (A) & (C) - (B) \\
\hline \hline DF & CO & 0,08072 & 0,08551 & 0,14839 & 0,06767 & 0,06288 \\
GO & CO & 0,46550 & 0,35224 & 0,61127 & 0,14577 & 0,25903 \\
MS & CO & 0,19029 & 0,16503 & 0,28638 & 0,09609 & 0,12135 \\
MT & CO & 0,29616 & 0,28594 & 0,49620 & 0,20004 & 0,21026 \\
\hline \hline TOTAL CO & & 1,03267 & 0,88872 & 1,54224 & 0,50957 & 0,65352 \\
\hline \hline AL & NE & 0,51415 & 0,52535 & 0,89442 & 0,38027 & 0,36907 \\
BA & NE & 1,36803 & 1,31548 & 2,02018 & 0,65215 & 0,70470 \\
CE & NE & 0,98496 & 0,97840 & 1,57743 & 0,59248 & 0,59903 \\
MA & NE & 0,91757 & 0,94445 & 1,55191 & 0,63435 & 0,60746 \\
PB & NE & 0,63692 & 0,60476 & 1,02961 & 0,39269 & 0,42486 \\
PE & NE & 0,95110 & 0,88628 & 1,48354 & 0,53244 & 0,59726 \\
RN & NE & 0,51646 & 0,52759 & 0,89825 & 0,38179 & 0,37066 \\
SE & NE & 0,51356 & 0,52472 & 0,89339 & 0,37983 & 0,36867 \\
\hline \hline TOTAL NE & & 6,40275 & 6,30704 & 10,34875 & 3,94599 & 4,04170 \\
\hline \hline
\end{tabular}

Continua... 


\begin{tabular}{|c|c|c|c|c|c|c|}
\hline$A C$ & NO & 0,44126 & 0,43200 & 0,73552 & 0,29426 & 0,30352 \\
\hline AM & NO & 0,39250 & 0,35237 & 0,59994 & 0,20743 & 0,24757 \\
\hline AP & NO & 0,43093 & 0,43093 & 0,73358 & 0,30265 & 0,30265 \\
\hline PA & NO & 0,78688 & 0,77189 & 1,31408 & 0,52720 & 0,54219 \\
\hline PI & NO & 0,53480 & 0,54572 & 0,92910 & 0,39430 & 0,38338 \\
\hline RO & NO & 0,36361 & 0,35542 & 0,60535 & 0,24175 & 0,24994 \\
\hline $\mathrm{RR}$ & NO & 0,31983 & 0,31326 & 0,53335 & 0,21352 & 0,22009 \\
\hline TO & NO & 0,54813 & 0,54813 & 0,93310 & 0,38497 & 0,38497 \\
\hline TOTAL NO & & 3,81795 & 3,74972 & 6,38402 & 2,56607 & 2,63430 \\
\hline ES & SE & 0,19774 & 0,17326 & 0,32250 & 0,12476 & 0,14924 \\
\hline MG & SE & 0,94458 & 0,89090 & 0,95772 & 0,01314 & 0,06681 \\
\hline RJ & SE & 0,46197 & 0,47527 & 0,32846 & $-0,13352$ & $-0,14682$ \\
\hline SP & SE & 0,39836 & 0,44195 & 0,21500 & $-0,18336$ & $-0,22695$ \\
\hline TOTAL SE & & 2,00264 & 1,98139 & 1,82367 & $-0,17897$ & $-0,15772$ \\
\hline PR & SU & 0,46320 & 0,47488 & 0,61989 & 0,15668 & 0,14501 \\
\hline RS & SU & 0,39175 & 0,38769 & 0,50628 & 0,11453 & 0,11859 \\
\hline $\mathrm{SC}$ & $\mathrm{SU}$ & 0,21860 & 0,21056 & 0,27516 & 0,05656 & 0,06460 \\
\hline TOTAL SU & & 1,07355 & 1,07313 & 1,40133 & 0,32778 & 0,32820 \\
\hline TOTAL (NO + NE + CO) & & 11,25337 & 10,94548 & 18,275 & 7,02163 & 7,32952 \\
\hline TOTAL (SU + SE) & & 3,07619 & 3,05452 & 3,225 & 0,14881 & 0,17048 \\
\hline \% TOTAL PARA FUNDOS & & 14,32956 & 14 & 21,5 & 7,17044 & 7,5 \\
\hline
\end{tabular}

Fonte: TCU, Constituição Federal 1988, Lei no 62/89. Elaborado pelo autor.

(A) Percentual médio da participação dos estados na receita do IPI e do IR entre 1981 e $1990^{13}$

(B) Percentual de participação dos estados no IPI e IR que corresponderiam ao ano de $1990^{14}$

(C) Percentual de participação dos estados no IPI e IR de acordo com CF-88 e Lei no 62/1989

Por fim, vale ressaltar que outro elemento que favoreceu a rápida aprovação dessa lei foi seu caráter provisório. Os coeficientes, preveem a lei e o acordo, deveriam ser revistos após a realização do censo populacional previsto para 1990, que forneceria as informações populacionais e econômicas para novo cálculo dos coeficientes. Além disso, decorridos alguns anos de vigência da nova estrutura fiscal, estariam também disponíveis informações sobre as finanças públicas sob esse novo arranjo. Os coeficientes definidos na lei complementar seriam, portanto, válidos somente até a execução orçamentária de 1991, inclusive.

\footnotetext{
${ }^{13}$ Foram considerados os anos de 1981, 1984, 1985, 1987, 1989 e 1990. Os outros anos não foram incluídos porque os coeficientes não constavam nas resoluções do TCU disponíveis para consulta.

${ }^{14}$ O TCU chegou a calcular esses coeficientes baseados na regra antiga, apesar de não terem sido utilizados devido à aprovação da nova regra (ver Brasil - TCU, Resoluções 240/89, 242 e 244/90).
} 
No entanto, a Lei no 62/89 regulou as transferências do FPE até, pelo menos, 2012. A lei aprovada continha em um de seus parágrafos (art.2으 $\S 3$ ) um dispositivo que permitiria sua vigência mesmo depois de 1992. Após 1992, e apesar das tentativas de parlamentares de diversos estados, nenhuma legislação veio a substituir a Lei no 62/1989. Os que menos ganharam no decorrer do tempo devido aos critérios serem fixos e devido à sua não revisão no momento previsto não conseguiram angariar apoio daqueles que mais ganharam com essa legislação. Ao menos, até isso tornar-se uma questão para o Supremo Tribunal Federal. 


\section{Conclusão}

As questões relativas à área de tributação própria das unidades da federação e as questões relacionadas às transferências fiscais ocuparam ambas um lugar central nas barganhas à cerca do desenho fiscal na Assembleia Nacional Constituinte de 1988. Tais questões dividiram regionalmente os constituintes em duas coalizões: Norte, Nordeste e Centro-Oeste, de um lado, Sul e Sudeste, de outro. As duas coalizões demandavam descentralização fiscal, mas divergiam quanto à forma que ela deveria tomar. A coalizão dos estados do Norte, Nordeste e Centro-Oeste demandava descentralização fiscal via aumento das transferências federais redistributivas, ao passo que a coalizão dos estados do Sul e Sudeste privilegiava propostas que descentralizavam o sistema via aumento da área de tributação própria dos estados. Estados pobres têm baixa capacidade de arrecadação fiscal. Demandavam, portanto, redistribuição da receita pública via transferências fiscais como forma de atenuar as desigualdades regionais de renda. Nesse sentido, a teoria do eleitor mediano que destaca o papel da distribuição territorial de renda na formação de preferências, conforme apresentada por Pablo Beramendi (2007, 2012), parece explicar bem a formação dessas coalizões. No entanto, durante o processo decisório, o debate em torno da redistribuição de renda deu lugar às preocupações com a distribuição da receita fiscal. Constituintes queriam garantir aumento de receita pública para seus estados via descentralização fiscal e, principalmente, garantir que seus estados não perdessem receita em relação ao status quo.

As regras do processo decisório também desempenharam um papel central na formação das coalizões. As regiões Norte e Nordeste juntas, que eram as regiões que concentram a maioria dos estados mais pobres, não formavam maioria em nenhuma arena decisória. Porém, juntos com o Centro-Oeste detinham maioria em três das quatro arenas da constituinte. Essas três regiões, juntas, com maioria, ditaram a forma que tomou a descentralização fiscal aprovada na Constituição de 1988. 
Os acordos principais ocorreram nas duas primeiras arenas decisórias da Constituinte: a Subcomissão Tributos, Participação e Distribuição de Receitas e a Comissão do Sistema Tributário, Orçamento e Finanças. A decisão final se aproximou das preferências da coalizão dos estados das regiões Norte, Nordeste e Centro-Oeste. Ou seja, a descentralização fiscal promovida pela Constituinte se deu marcadamente através de aumento de transferências constitucionais que promoviam a redistribuição interregional de receita pública.

Apesar dessa característica fundamental que tomou a descentralização fiscal, ocorreu também descentralização da área de tributação própria, favorecendo os estados das regiões mais ricas, que foram também beneficiados por transferências constitucionais via Fundo de Ressarcimento. No cômputo geral, as reformas introduzidas não resultaram em perdas de receita para nenhum estado.

O que motivou a maioria a adotar regras que não impusessem perdas de receita para estados da coalizão minoritária foi justamente o vínculo partidário dos constituintes. Os constituintes, que eram oriundos de diversos estados e regiões, eram também membros de partidos nacionais. O vínculo partidário, de um lado, e o vínculo estadual e regional, de outro, geraram um duplo incentivo para os constituintes. Dados seus vínculos estaduais e regionais, eles queriam garantir aumento de receita fiscal para seus respectivos estados e evitar que a receita diminuísse em relação ao status quo. Enquanto membros de partidos nacionais, evitaram a imposição de perdas aos outros estados na medida em que isso poderia punir eleitoralmente companheiros partidários e, portanto, o próprio partido. Por isso a maioria composta por estados das regiões Norte, Nordeste e Centro-Oeste negociou com a minoria. O resultado foi a aprovação de um sistema que beneficiava todos os estados, conforme informavam os dados de receita pública e as simulações dos impactos das mudanças que estavam disponíveis aos constituintes. Contudo, o resultado final claramente se aproximou do tipo de descentralização fiscal desejado pela coalizão majoritária. 
Se quisermos extrapolar esse estudo de caso, temos que levar em consideração as características essenciais do processo decisório estudado aqui: a desigualdade regional de renda; a regra de decisão por maioria; a decisão tomada no centro do sistema decisório, sem veto formal de qualquer subunidade ou de outro poder, por parlamentares eleitos nos estados, mas membros de partidos suprarregionais. Guardadas essas semelhanças fundamentais, podemos verificar que essa estrutura de incentivos pode gerar resultados semelhantes em outros contextos quando o que está em jogo são decisões sobre o desenho fiscal que envolva a realocação horizontal das receitas públicas. É essa a configuração que se repete nas decisões que estão em curso no caso da reforma do FPE e nas regras de distribuição dos recursos do Pré-sal entre os estados. A menos que a União faça o papel de coordenação e busque impor uma agenda, alterando o equilíbrio de forças destacado aqui, a solução para a partilha pode ser o aumento do montante global das transferências caso os representantes não queiram punir seus estados, ou mesmo seu próprio partido. Nesse sentido, a receita do "Pré-Sal", por ser uma receita extra e inesperada, poderia justamente cumprir o papel que a descentralização vertical cumpriu na Constituinte: permitir reformar o FPE sem que haja imposição de perdas orçamentárias. 


\section{Bibliografia}

Abrucio, F. (1998). Os Barões da Federação: os governadores e a redemocratização brasileira (1st ed.). São Paulo - SP: Hucitec.

Abrucio, F., \& Samuels, D. (1997, July 20). Efeitos da reeleição no sistema político. O Estado de São Paulo. São Paulo - SP.

Alesina, A., \& Perotti, R. (1998). Economic Risk and Political Risk in Fiscal Unions. Economic Journal, 108(July), 989-1008.

Ames, B. (1995). Electoral Strategy under Open-List Proportional Representation. American Journal of Political Science, 39(2), 406-433.

Arretche, M. T. S. (2005). Quem taxa e quem gasta: A barganha federativa na Federação Brasileira. Revista de Sociologia e Política, 24, 69-85.

Arretche, M. T. S. (2007). The Veto Power of sub-national governments in Brazil: Political Institutions and Parliamentary Behaviour in the Post-1988 Period. Brazilian Political Science Review, 2.

Arretche, M. T. S. (2009). Continuidades e Descontinuidades da Federação Brasileira: De como 1988 Facilitou 1995, 52(2), 377-423.

Arretche, M. T. S. (2010). Federalismo e Igualdade Territorial: Uma Contradição em Termos? DADOS, 53(3), 587-620.

Arretche, M. T. S. (2012). Democracia, federalismo e centralizaçao no Brasil (1st ed., p. 232). Rio de Janeiro - RJ: FGV; Fiocruz.

Assembleia Nacional Constituinte - Subcomissao de Tributos Participação e Distribuição de Receita. (1987a). Diários da Assembléia Nacional Constituinte (p. Ata das Reuniões - Supl. 84 p. 45 26/6/1987). Brasilia - DF.

Assembleia Nacional Constituinte - Subcomissao de Tributos Participação e Distribuição de Receita. (1987b). Diários da Assembléia Naional Constituinte (p. Ata das Reuniões - Supl. 84 p. $74-1 / 5 / 1987)$. Brasilia - DF.

Assembleia Nacional Constituinte - Subcomissao de Tributos Participação e Distribuição de Receita. (1987c). Diários da Assembléia Nacional Constituinte (p. Ata das Reuniões - Supl. 53 p. $147-1 / 5 / 1987)$. Brasilia - DF.

Assembleia Nacional Constituinte - Subcomissao de Tributos Participação e Distribuição de Receita. (1987d). Diários da Assembléia Naional Constituinte (p. Ata das Reuniões - Supl.85 p. $74-1 / 5 / 1987)$. Brasilia - DF. 
Beramendi, P. (2007). Inequality and the Territorial Fragmentation of Solidarity. International Organization, 61(04), 783-820. doi:10.1017/S0020818307070270

Beramendi, P. (2012). The Political Geography of Inequality ( $1^{\circ}$ Ed.). New York - NY: Cambridge University Press.

Bolton, P., \& Roland, G. (1997). The breakup of nations: a political economy analysis. The Quartely Journal of Economics, (November).

Brasil Lei ${ }^{\circ} 5.172$ de 25 de Outurbro de 1966. Dispõe sobre o Sistema Tributário Nacional e institui normas gerais de direito tributário aplicáveis à União, Estados e Municípios (1966).

Brasil Constituição da República Federativa do Brasil (1967). Brasilia - DF: Senado Federal.

Brasil Constituição da República Federativa do Brasil (1988). Brasilia - DF: Senado Federal.

Brasil - Tribunal de Contas da União (TCU). (1989). Resolução n 240 de 13 de Dezembro de 1990. Aprova os percentuais e os coeficientes individuais do FPE. Brasília - DF: Tribunal de Contas da União.

Brasil - Tribunal de Contas da União (TCU). (1990a). Resolução nº 242 de 02 de Janeiro de 1990. Aprova os percentuais e os coeficientes individuais do FPE. Brasília - DF: Tribunal de Contas da União.

Brasil - Tribunal de Contas da União (TCU). (1990b). Resolução n 244 de 05 de Junho de 1990. Aprova os percentuais e os coeficientes individuais do FPE. Brasília - DF: Tribunal de Contas da União.

Brasil, C. 1945 Emenda Constitucional n ${ }^{\circ} 18$ de $1^{\circ}$ de Dezembro de 1965. Reforma do sistema tributário (1965).

Brasil. Presidência da República. Decreto $n^{\circ} N^{\circ} 91.450$ de 18 de julho de 1985. Institui a Comissão Provisória de Estudos Constitucionais. (1985). Brasilia - DF.

Brennan, G., \& Buchanan, J. (1980). The Power to Tax: Analytical Foundations of a Fiscal Constitution. New York - NY: Cambridge University.

Buchanan, J. (1996). Buchanan.Federalism(1995).pdf, 25(2), 19-27.

Cossio, F. A. (2000). Disparidades econômicas inter-regionais, capacidade de recursos tributários, esforço fiscal e gasto público no federalismo brasileiro. Rio de Janeiro: PUC/RJ.

Cremer, J. (2013). Political Confederation, 93(1), 69-83.

Diários da Câmara dos Deputados (DCD). (1989). Diário da Câmara dos Deputados 31/10/89. Brasilia - DF: Câmara dos Deputados. 
Estevez-Abe, M., Iversen, T., \& Soskice, D. (2001). Social Protection and the formation of Skill: A reinterpretation of the Welfare State. In P. Hall \& D. Soskice (Eds.), Varieties of Capitalism: the institutional foundations of comparative advantage. Oxford: Oxford University Press.

Federação das Associações de Fiscais de Tributos Estaduais (FAFITE). (1988). Proposta de Sistema Tributário - FAFITE. Arquivos da Constituinte. Câmara dos Deputados. Brasilia - DF.

Figueiredo, A. C., \& Limongi, F. (1999). Executivo e Legislativo na Nova Ordem Constitutional. São Paulo - SP: FGV.

Figueiredo, A. C., \& Limongi, F. (2000). Presidential Power, Legislative Organization, and Party Behavior in the Legislature. Comparative Politics, 32(2), 151-170.

Gibson, E. L., Calvo, E. F., \& Falleti, T. G. (2003). Federalismo Realocativo: sobre-representaçao Legislativa e Gastos Públicos no Hemisfério Ocidental. Opinião Pública, IX(1), 98-123.

Hayek, F. (1939). The Economic Conditions of Interstate Federalism. Individualism and Economic Order. Chicago - IL: University of Chicago.

Henderson, V. (2000). The effects of urban concentration on economic growth. Cambridge.

IBGE. (1988). Pesquisa Nacional por Amostra de Domicílios - V.11 tomo 1 (pp. 1-244). Rio de Janeiro - RJ: Instituto Brasileiro de Geografia Estatística.

Inman, R. P., \& Rubinfeld, D. L. (1997). Rethinking Federalism. Journal of Economic Perspectives, 11(4), 43-64. doi:10.1257/jep.11.4.43

IPEA - Instituto de Pesquisa Econômica Aplicada. (1987a). Proposta de Reforma do Sistema Tributário Brasileiro - TD 104. Rio de Janeiro - RJ.

IPEA - Instituto de Pesquisa Econômica Aplicada. (1987b). Proposta de Reforma do Sistema Tributário Brasileiro - TD 108. Instituto de Pesquisa Econômica Aplicada - IPEA.

Iversen, T., \& Soskice, D. (2001). An Asset Theory of Social Policy Preferences. American Political Science Review, 95(4), 875-93.

Junqueira, M. de O. (2010). O Nó Tributário: porque não se aprova uma reforma tributária no Brasil. Universidade de São Paulo.

Lamounier, B. (1992). Estrutura institucional e governabilidade na década de 90 . In J. P. dos R. Veloso (Ed.), O Brasil e as reformas políticas (1st ed., pp. 23-47). Rio de Janeiro - RJ: José Olympio.

Lamounier, B. (1994). Brazil: Toward Parlamentarism? In J. Linz \& A. Valenzuela (Eds.), The Failure of Presidential Democracy: The Case of Latin America. (1st ed.). Baltimore: The Johns Hopkins University Press. 
Leme, H. J. C. (1992). O Federalismo na Constituinte de 1988: representação política e distribuição de recursos tributários. Universidade de Campinas.

Lijphart, A. (1999). Modelos de Democracia: desempenho e padrões de governo em 36 países ( $2^{\mathrm{a}}$ ed.). Rio de Janeiro - RJ: Civilizaçao Brasileira.

Mainwarning, S. (1997). Multipartism, Robust Federalism and Presidentialism in Brazil. In S. Mainwarning \& M. S. Shugart (Eds.), Presidentialism and Democracy in Latin America (1st ed.). Cambridge: Cambridge University Press.

Nogueira, J. C. A. (1995). O Financiamento Público e Descentralização fiscal no Brasil. Rio de Janeiro - RJ.

Oates, W. (1972). Fiscal Federalism. New York - NY: H. B. Jovanovich.

Oliveira, F. A. de. (1995a). O sistema fiscal brasileiro: evoluçao e crise (1965/1985). São Paulo - SP.

Oliveira, F. A. de. (1995b). Autoritarismo e crise fiscal no Brasil (1964-1984) (1ed ed.). São Paulo SP: Hucitec.

Oliveira, F. A. de. (1995c). A crise da federação: da oligarquia à globalização. In J. R. Afonso \& P. L. B. Silva (Eds.), A federação em perspectiva. Ensaios Selecionados. São Paulo - SP: Fundaçao do Desenvolvimento Administrativo.

Panizza, U. (1999). On the determinants of fiscal centralization: Theory and evidence. Journal of Public Economics, 74(1), 97-139. doi:10.1016/S0047-2727(99)00020-1

Paterson, P., \& Rom, M. C. (1990). Welfare Magnets: a new case for a national standard. Washington - DC: The Brookings Institutions.

Peterson, P. (1995). The Price of Federalism. Washington - DC: The Brookings Institutions.

Prud'homme, R. (1995). The Dangers of Descentralization. The World Bank Research Observer, 10(2), 201-220.

Qian, Y., \& Weingast, B. R. (2011). Federalism as a Commitment to Preserving Market Incentives, 11(4), 83-92.

Research and Economic Analyses Division - State of Hawaii. (2008). Research and Economic Analysis Division February 2008. Hawaii.

Riker, W. (1975). Federalism. In F. Greenstein \& N. Polsby (Eds.), Handbook of Political Science. Addison-Wesley.

Rodden, J. (2005). Federalismo e descentralização em perspectiva Comparada: sobre significados e medidas. Revista de Sociologia e Política, 24, 9-27. 
Rodden, J. (2009). Federalism and Inter-regional Redistribution. Documents de Treball de l'IEB. Barcelona.

Sambanis, N., \& Milanovic, B. (2009). Explaining the Demand for Sovereignty.

Samuels, D. (2003). Ambition, Federalism, and Legislative Politics in Brazil (1st ed., p. 243). Cambridge: Cambridge University Press.

Scherer, F. M. (1980). Industrial market structure and economic performance ( $2^{\circ}$ ed.). Boston: Hougton Mifflin Company.

Senado Federal. (1988a). Assembléia Nacional Constituinte - Atas de Comissões - Subcomissão de Tributos Participação e Distribuição de Receitas (STPDR) (pp. 1-251). Brasília - DF. Retrieved from http://www.senado.gov.br/publicacoes/anais/asp/CT_Abertura.asp

Senado Federal. (1988b). Assembléia Nacional Constituinte - Atas de Comissões - Comissão do Ssitema Tributário, Orçamento e Finanças (pp. 1-207). Brasília - DF.

Souza, C. (1994). Political and Financial Decentralization in Democratic Brazil. Local Government Studies, 20(4), 588-609.

Souza, C. (1996). Redemocratization and Decentralization in Brazil: The Strength of the Member States. Development and Change, 27(3), 529-555. doi:10.1111/j.1467-7660.1996.tb00602.x

Souza, C. (1997). Constitutional Engineering in Brazil (1ed ed., p. 211). New York - NY: Macmillan Press PTD.

Souza, C. (2007). Estado da arte da Pesquisa em Políticas Públicas. In G. Hochman, M. Arretche, \& E. Marques (Eds.), Política Públicas no Brasil (1 ${ }^{\mathrm{a}}$ ed., p. 398). Rio de Janeiro: FIOCRUZ.

Stepan, A. (1999). Para uma Nova Análise Comparativa do Federalismo e da Democracia: Federaçoes que Restringem ou Ampliam o Poder do Demos. DADOS, 42(2).

Tauer, L. W. (1992). Diversification of production activities across individual states. Journal of Production Agriculture, 5, 210-214.

Tiebout, C. M. (1956). A pure theory of local expenditures. The journal of political economy, 64(5), 416-424. Retrieved from http://www.jstor.org/stable/10.2307/1826343

Weingast, B. R. (1995). The Economic Role of Political Institutions?]: Federalism and MarketPreserving Economic Development. Journal of Law, Economics \& Organization, 11(1), 1-31.

Weingast, B. R. (2007). Second Generation Fiscal Federalism?: Implications for Decentralized Democratic. mimeo. Retrieved from http://papers.ssrn.com/sol3/papers.cfm?abstract_id $=1153440$ 
Weingast, B. R. (2009). Second generation fiscal federalism: The implications of fiscal incentives. Journal of Urban Economics, 65(3), 279-293. doi:10.1016/j.jue.2008.12.005

Wibbels, E. (2005). Decentralized Governance, Constitution Formation and Redistribution. Constitutional Political Economy, 16, 161-188. 


\section{A. Apêndice}

\section{A.1. Construção das variáveis para teste da hipótese do modelo do eleitor mediano}

Basicamente, utilizou-se a PNAD de 1987. A PNAD de 1987 (e assim se manteve até 2002) não cobria a região rural do Norte do país.

\section{Proporção da população desempregada ( $\beta$ )}

Indicador

$$
\beta=\frac{\text { População empregada }}{\text { População total }}
$$

\section{Operacionalização}

Para o ano de 1987, a variável utilizada foi a "5100 - Horas em todos os trabalhos". Essa variável indica o número de horas trabalhadas por semana por uma pessoa em seu trabalho principal e nos outros trabalhos que possui (IBGE, 1988). As pessoas que respondiam a essa questão foram considerados empregadas.

\section{Renda do eleitor mediano $\left(w_{m}\right)$}

\section{Operacionalização}

Para o ano de 1987, a variável da PNAD utilizada foi a "601 - Renda mensal de todos os trabalhos". A renda foi deflacionada pelo IPCA para reais (R\$) de 2000, pois o valor do PIB per capta estadual disponível estava em reais de 2000.

\section{Indicador de especialização econômica $(\sigma)$}

\section{Indicador}

Há diversos indicadores de especialização econômica. Um dos mais utilizados é o índice de Herfindahl (READ-Hawaii,2008; Scherer, 1980; Tauer, 1992). Esse índice é 
utilizado para medir a concentração da atividade industrial, mas pode ser utilizado também para medir a concentração do emprego em determinada área de atividade econômica de modo geral.

$$
\text { Herfindahl Index }=\sum_{i} S_{i}^{2}
$$

Onde $S_{\mathrm{i}}$ representa a parcela da população empregada no setor $i$. $O$ índice varia de zero a um. Quanto mais concentrado em determinado setor estiver a população empregada, menos diversificada é a economia e mais o índice se aproxima de 1 . Ou seja, 1 indica total especialização econômica, com toda população empregada em um só setor da economia.

Como no argumento desenvolvido pelo modelo assume-se que o risco de perda do trabalho está diretamente associado com o grau de especialização econômica, adoto como proxy para esse risco, seguindo o modelo proposto por Beramendi, o índice de Herfindahl. Ou seja:

$$
\sigma^{2}=\sum_{i} S_{i}^{2}
$$

\section{Operacionalização}

Para o ano de 1987, a variável utilizada foi a "504 - Atividade / Ramo do negócio". Essa é uma variável categórica que indica o ramo de atividade econômica exercida pelo entrevistado. 


\begin{tabular}{|c|c|}
\hline Variável & Informação \\
\hline \multirow[t]{5}{*}{$\overline{\beta \beta}$} & Definição: proporção da população empregada \\
\hline & Fonte: IBGE - PNAD 1987 (var: 5100) e Censo 2010 \\
\hline & Operacionalização: \\
\hline & $\beta=$ População empregada \\
\hline & População total \\
\hline \multirow[t]{4}{*}{$\lambda$} & Definição: proporção da população desempregada \\
\hline & Fonte: IBGE - PNAD 1987 e Censo 2010 \\
\hline & Operacionalização: \\
\hline & $\lambda=1-\beta$ \\
\hline \multirow[t]{2}{*}{$w_{m}$} & Definição: renda do eleitor mediano \\
\hline & Fonte: IBGE - PNAD 1987 (var: 601) e Censo 2010 \\
\hline \multirow[t]{2}{*}{ Y } & Definição: PIB per capta dos estados e da União \\
\hline & Fonte: Instituto de Pesquisa Econômica Aplicada (IPEA) \\
\hline \multirow[t]{5}{*}{$\sigma^{2}$} & Definição: indicador de diversificação econômica \\
\hline & Fonte: PNAD 1987 (var: 504) e Censo 2010 \\
\hline & Operacionalização: \\
\hline & $\sigma^{2}=\sum S_{i}^{2}$ \\
\hline & sendo $S_{i}$ a parcela da população da região ou do país empregada no setor $i$. \\
\hline
\end{tabular}

\section{A.2. Dotação e Critérios de rateio do FPE entre 1966 e 2012}

Porcentagem do IR e IPI destinado ao FPE entre 1966 e 2012

\begin{tabular}{|c|c|c|}
\hline Legislação & Vigência & Proporção do IR e do IPI para o FPE ( $\left.p_{\mathrm{FPE}}\right)$ \\
\hline $\mathrm{EC}$ no 18 de 1965 & $1967-1968$ & $10 \%$ \\
\hline AC no 40 de 1968 & 1969-1975 & $5 \%$ \\
\hline \multirow[t]{4}{*}{ EC no 5 de 1975} & 1976 & $6 \%$ \\
\hline & 1977 & $7 \%$ \\
\hline & 1978 & $8 \%$ \\
\hline & $1979-1980$ & $9 \%$ \\
\hline \multirow[t]{2}{*}{ EC no 17 de 1980} & 1981 & $10 \%$ \\
\hline & $1982-1983$ & $10,5 \%$ \\
\hline \multirow[t]{2}{*}{ EC no 23 de 1983} & 1984 & $12,5 \%$ \\
\hline & 1985 & $14 \%$ \\
\hline EC no 27 de 1985 & $1985-1988$ & $14 \%$ \\
\hline \multirow[t]{6}{*}{ LC no 62 de 1989} & 1988 & $18 \%$ \\
\hline & 1989 & $19 \%$ \\
\hline & 1990 & $19,5 \%$ \\
\hline & 1991 & $20 \%$ \\
\hline & 1992 & $20,5 \%$ \\
\hline & $1993-2012$ & $21,5 \%$ \\
\hline
\end{tabular}

Fonte: legislação citada. Elaborado pelo autor. 
O valor final do Fundo de Participação dos Estados (FPE) é composto por uma porcentagem do IPI e do IR líquidos, ou seja, descontados restituições e incentivos fiscais. A tabela acima apresentada a variação da definição desses percentuais ao longo do tempo no Brasil. O total destinado ao FPE é dado por:

$$
\begin{gathered}
R_{\text {Bruta }}=I P I+I R \\
R_{\text {Liquida }}=R_{\text {Bruta }}-\text { Restituições }- \text { Incentivos Fiscais } \\
F P E_{\text {Total }}=p_{F P E} * R_{\text {Liquida }}
\end{gathered}
$$

\section{Critério de rateio entre os estados entre 1966-1975}

O critério de rateio do FPE contido nos artigos 88, 89 e 90 do Código Tributário Nacional de 1966 (Lei no 5172/66), até o Decreto-Lei no 1.434 de 1975 era dado pela seguinte fórmula:

$$
F P E_{U F}=\left(0,05 * A_{U F}+0,95 * \frac{f_{P_{o p} U F} * f_{\text {RendaUF }}}{\sum f_{\text {Pop }_{U F}} * f_{\text {RendaUF }}}\right) * F P E_{\text {Total }}
$$

onde $A_{U F}$ é a área territorial relativa do estado, $f_{P o p}$ e $f_{\text {Renda }}$ são respectivamente os fatores representativos da população estadual e do inverso da renda per capta estadual. Esses dois fatores foram definidos pelo código tributário de 1966 conforme as duas tabelas da sequencia.

\section{Critério de rateio entre os estados entre 1976-1988}

Depois de 1975, 20\% do total do FPE era dividido exclusivamente entre estados do norte e nordeste. Esses ficavam com:

$$
F P E_{U F}=\left(0,05 * A_{U F}+0,95 * \frac{f_{\text {Pop }_{U F}} * f_{\mathrm{Re} n d a U F}}{\sum f_{\text {Pop }_{U F}} * f_{\text {RendaUF }}}\right) * 0,2 * F P E_{\text {Total }}
$$

Todos os estados, inclusive os do norte e nordeste, recebiam:

$$
F P E_{U F}=\left(0,05 * A_{U F}+0,95 * \frac{f_{\text {Pop }_{U F}} * f_{\text {Re ndaUF }}}{\sum f_{\text {Pop }_{U F}} * f_{\text {RendaUF }}}\right) * 0,8 * F P E_{\text {Total }}
$$


Fator representativo da população

\begin{tabular}{|c|c|}
\hline Proporção da população no estado em relação ao total & $\boldsymbol{f}_{\text {Pop }}$ \\
\hline I - Até $2 \%$ & 2,0 \\
\hline II - Acima de 2\% até 5\%: & --- \\
\hline a) pelos primeiros 2\% & 2,0 \\
\hline b) para cada 0,3\% ou fração excedente, mais & 0,3 \\
\hline III - acima de 5\% até 10\%: & --- \\
\hline a) pelos primeiros 5\% & 5,0 \\
\hline b) para cada 0,5\% ou fração excedente, mais & 0,5 \\
\hline IV - acima de 10\% & 10,0 \\
\hline
\end{tabular}

Fonte: Lei 5172/66, art.89.

Fator representativo da população - Quadro estendido

\begin{tabular}{|l|c|}
\hline \multicolumn{1}{|c|}{ Proporção da população no estado em relação ao total } & $f_{\text {Pop }}$ \\
\hline Até $2 \%$ & 2,0 \\
\hline Acima de $2,0 \%$ até $2,3 \%$ & 2,3 \\
\hline Acima de $2,3 \%$ até $2,6 \%$ & 2,6 \\
\hline Acima de $2,6 \%$ até $2,9 \%$ & 2,9 \\
\hline Acima de $2,9 \%$ até $3,2 \%$ & 3,2 \\
\hline Acima de $3,2 \%$ até $3,5 \%$ & 3,5 \\
\hline Acima de $3,5 \%$ até $3,8 \%$ & 3,8 \\
\hline Acima de $3,8 \%$ até $4,1 \%$ & 4,1 \\
\hline Acima de $4,1 \%$ até $4,4 \%$ & 4,4 \\
\hline Acima de $4,4 \%$ até $4,7 \%$ & 4,7 \\
\hline Acima de $4,7 \%$ até $5,0 \%$ & 5,0 \\
\hline Acima de $5,0 \%$ até $5,5 \%$ & 5,5 \\
\hline Acima de $5,5 \%$ até $6,0 \%$ & 6,0 \\
\hline$\ldots \ldots . . . . . . . . . .$. & \\
\hline Acima de $9,5 \%$ & 10,0 \\
\hline
\end{tabular}

Fonte: Lei 5172/66, art.89 


\section{Fator representativo da renda}

O índice relativo da renda per capta da UF é dado por:

$$
\text { indice relativo }=\frac{\text { renda per capta }}{\sum_{U F} \text { renda per } \text { capta }_{U F}}
$$

\begin{tabular}{|l|c|}
\hline \multicolumn{1}{|c|}{ Inverso do índice relativo à renda per capta } & $\boldsymbol{f}_{\text {Renda }}$ \\
\hline Até 0,0045 & 0,4 \\
\hline Acima de 0,0045 até 0,0055 & 0,5 \\
\hline Acima de 0,0055 até 0,0065 & 0,6 \\
\hline Acima de 0,0065 até 0,0075 & 0,7 \\
\hline Acima de 0,0075 até 0,0085 & 0,8 \\
\hline Acima de 0,0085 até 0,0095 & 0,9 \\
\hline Acima de 0,0095 até 0,0110 & 1,0 \\
\hline Acima de 0,0110 até 0,0130 & 1,2 \\
\hline Acima de 0,0130 até 0,0150 & 1,4 \\
\hline Acima de 0,0150 até 0,0170 & 1,6 \\
\hline Acima de 0,0170 até 0,0190 & 1,8 \\
\hline Acima de 0,0190 até 0,0220 & 2,0 \\
\hline Acima de 0,220 & 2,5 \\
\hline
\end{tabular}

Fonte: Lei 5172/66, art.89

\section{Critério de rateio entre 1988 e 2012}

O critério de Rateio que vigorou até 2012, fixos e definidos no Anexo Único da Lei Complementar no 62 de 1989, são os seguintes:

Estados do Norte, Nordeste e Centro-Oeste:

$$
F P E_{U F}=p_{U F}\left(0,85 * F P E_{\text {Total }}\right)
$$

Estados do Sul e Sudeste:

$$
F P E_{U F}=p_{U F}\left(0,15^{*} F P E_{\text {Total }}\right)
$$


Cota-Parte de cada estado no FPE de 1989 até 2012

\begin{tabular}{|c|c|c|}
\hline UF & Região & Participação (puF) \\
\hline Acre & NO & 3,421 \\
\hline Amapá & NO & 3,412 \\
\hline Amazonas & NO & 2,7904 \\
\hline Pará & NO & 6,112 \\
\hline Rondônia & NO & 2,8156 \\
\hline Roraima & NO & 2,4807 \\
\hline Tocantins & NO & 4,34 \\
\hline Alagoas & $\mathrm{NE}$ & 4,1601 \\
\hline Bahia & $\mathrm{NE}$ & 9,3962 \\
\hline Ceará & $\mathrm{NE}$ & 7,3369 \\
\hline Maranhão & $\mathrm{NE}$ & 7,2182 \\
\hline Paraíba & $\mathrm{NE}$ & 4,7889 \\
\hline Pernambuco & $\mathrm{NE}$ & 6,9002 \\
\hline Piauí & $\mathrm{NE}$ & 4,3214 \\
\hline Rio Grande do & $\mathrm{NE}$ & 4,1779 \\
\hline Sergipe & $\mathrm{NE}$ & 4,1553 \\
\hline Distrito Federal & $\mathrm{CO}$ & 0,6902 \\
\hline Goiás & $\mathrm{CO}$ & 2,8431 \\
\hline Mato Grosso & $\mathrm{CO}$ & 2,3079 \\
\hline Mato Grosso do & $\mathrm{CO}$ & 1,332 \\
\hline Espírito Santo & SE & 1,5 \\
\hline Minas Gerais & SE & 4,4545 \\
\hline Rio de Janeiro & SE & 1,5277 \\
\hline São Paulo & SE & 1 \\
\hline Paraná & SL & 2,8832 \\
\hline Rio Grande do & $S L$ & 2,3548 \\
\hline Santa Catarina & SL & 1,2798 \\
\hline TOTAL & $\mathrm{SE}+\mathrm{SL}$ & $15 \%$ \\
\hline TOTAL & $\mathrm{NO}+\mathrm{NR}+\mathrm{CO}$ & $85 \%$ \\
\hline TOTAL GERAL & & 100 \\
\hline
\end{tabular}


Resumo dos critérios de rateio do percentual global do FPE entre as macrorregiões adotados no Brasil entre 1966 e 2012

\begin{tabular}{|c|c|c|}
\hline Vigência & $\begin{array}{c}\text { Cota } \\
\text { regional }\end{array}$ & Critérios de rateio \\
\hline $1966-1975^{(1)}$ & Todas & $F P E_{U F}=\left(0,05 * A_{U F}+0,95 * \frac{f_{P_{o p} U F} * f_{\text {RendaUF }}}{\sum f_{\text {Pop }_{U F}} * f_{\text {RendaUF }}}\right) * F P E_{\text {Total }}$ \\
\hline \multirow[t]{2}{*}{$\begin{array}{l}1976- \\
1989^{(2) *}\end{array}$} & NO e NE & $F P E_{U F}=\left(0,05 * A_{U F}+0,95 * \frac{f_{P_{o p} U F} * f_{\text {RendaUF }}}{\sum f_{P_{o p} U F} * f_{\text {RendaUF }}}\right) * 0,2 * F P E_{\text {Total }}$ \\
\hline & Todas & $F P E_{U F}=\left(0,05 * A_{U F}+0,95 * \frac{f_{\text {Pop }_{U F}} * f_{\mathrm{RendaUF}}}{\sum f_{\text {Pop }_{U F}} * f_{\mathrm{Re} \text { ndaUF }}}\right) * 0,8 * F P E_{\text {Total }}$ \\
\hline \multirow[t]{2}{*}{$1990-2012^{(3)}$} & $\begin{array}{ll}\mathrm{NO}, & \mathrm{NE}, \\
\mathrm{CO} & \\
\end{array}$ & $F P E_{U F}=p_{U F}\left(0,85 * F P E_{\text {Total }}\right)$ \\
\hline & SL, SE & $F P E_{U F}=p_{U F}\left(0,15 * F P E_{\text {Total }}\right)$ \\
\hline
\end{tabular}

* Obs: para os anos de 1976 e 1977 o percentual das regiões Norte e Nordeste foi de $10 \%$

(1) Emenda Constitucional no 18/65; Ato Complementar no 40/68

(2) Emenda Constitucional no 5/75; Decreto-Lei no 1434/75

${ }^{\text {(3) }}$ Constituição Federal de 1988; Lei Complementar no 62/1989 


\section{A. Anexos}

\section{A.1. Informações sobre receita pública}

As estimativas sobre receita pública foram retiradas de dois textos do IPEA, que foram preparados com a finalidade de subsidiar a reforma fiscal da constituinte (IPEA, 1987a, 1987b). As estimativas utilizadas aqui são de 1984. O texto para discussão número 104 do IPEA continha o valor total estimado da arrecadação, tanto no status quo quanto o que seria esperado pela reforma. Por isso, foi possível estimar a arrecadação de praticamente todos os impostos separadamente, tomando como base 1984 . No caso dos impostos únicos, esse volume continha apenas o valor agregado. Por isso, foi utilizado o texto número 108, que continha o valor desagregado de cada imposto único. Como as fontes e as escalas são diferentes nos dois tomos, o procedimento adotado foi utilizar o percentual relativo dos impostos únicos conforme tabela desagregada, e multiplicar esses percentuais pelo total da tabela que continha o dado agregado. Assim, manteve-se a compatibilidade dos valores.

Os valores absolutos estão apresentados no quadro abaixo. Sua unidade é cruzeiros, mas ela não importa e não foi modificada, uma vez que se trabalha aqui apenas em termos relativos. Ou seja, o importante é a taxa de aumento na arrecadação de cada subunidade em relação ao status quo, bem como a origem da receita, se via arrecadação própria, transferências proporcionais ou transferências negociadas. Para fazer essa comparação, tomou-se os valores no status quo como ponto fixo, ou seja, dividiu-se cada linha pelo valor da linha no status quo. A unidade de medida, portanto, é irrelevante, já que se está interessado no taxa de aumento ou diminuição. A tabela com as taxas de aumento estão no corpo do texto. 


\begin{tabular}{|c|c|c|c|c|c|c|}
\hline & SQ & $\begin{array}{c}\text { Sec.Faz. } \\
\text { NO,NE e CO }\end{array}$ & AA & IPEA & FAFITE & CF 1988 \\
\hline \multicolumn{7}{|c|}{ Área de Tributação exclusiva } \\
\hline União & $28.693,80$ & $27.455,70$ & $28.304,80$ & $27.066,70$ & $26.992,00$ & $27.229,80$ \\
\hline Estados & $19.293,70$ & $21.701,80$ & $24.124,70$ & $26.709,80$ & $25.604,00$ & $21.374,70$ \\
\hline Municípios & $1.655,00$ & $1.257,00$ & $2.234,00$ & $1.257,00$ & $1.154,50$ & $2.105,50$ \\
\hline \multicolumn{7}{|c|}{ Transferências proporcionais } \\
\hline da união $p / U F$ & 717,83 & & $2.398,58$ & & & 483,10 \\
\hline da união $\mathrm{p} /$ Mun & 208,88 & & $1.574,29$ & & & 20,90 \\
\hline \multicolumn{7}{|c|}{ Transferências redistributivas } \\
\hline da união $p / U F$ & $3.260,16$ & $6.040,25$ & $3.597,66$ & $3.789,34$ & $3.778,88$ & $4.992,12$ \\
\hline da união $p /$ Mun & $3.871,44$ & $6.314,81$ & $3.397,79$ & $4.060,01$ & $4.048,80$ & $4.584,60$ \\
\hline \multicolumn{7}{|c|}{ Transferências proporcionais } \\
\hline do estado $\mathrm{p} /$ Mun & $4.147,25$ & $5.456,75$ & $3.666,40$ & $6.708,75$ & $5.120,80$ & $5.608,22$ \\
\hline Rec. União Tot Liq & $20.635,50$ & $15.100,64$ & $17.336,48$ & $19.217,36$ & $19.164,32$ & $17.149,08$ \\
\hline Rec. UF Total Liq & $19.124,44$ & $22.285,30$ & $26.454,54$ & $23.790,39$ & $24.262,08$ & $21.241,70$ \\
\hline Rec. Mun Total Liq & $9.882,57$ & $13.028,56$ & $10.872,48$ & $12.025,76$ & $10.324,10$ & $12.319,22$ \\
\hline
\end{tabular}

Fonte: IPEA, 1985, Tabela I.2, pg. 36, e Tabela A.I.2, pg.52. Elaboração própria

\begin{tabular}{lccc}
\hline \hline & STPDR & CSTOF & CSist (Projeto A) \\
\hline \hline Área de Tributação exclusiva & & & \\
União & $27.188,00$ & $27.188,00$ & $27.229,80$ \\
Estados & $21.776,50$ & $21.416,50$ & $21.374,70$ \\
Municípios & $1.257,00$ & $1.617,00$ & $2.105,50$ \\
\hline Transferências proporcionais & & & \\
da união p /UF & 192,03 & 369,57 & 364,74 \\
da união p/ Mun & & & 20,90 \\
\hline Transferências redistributivas & & & \\
da união p/ UF & $4.177,08$ & $4.788,36$ & $4.992,12$ \\
da união p/ Mun & $4.584,60$ & $4.584,60$ & $4.584,60$ \\
\hline Transferências proporcionais & & & \\
do estado p/ Mun & $5.744,22$ & $5.447,92$ & $5.455,40$ \\
\hline Receita União Total Liq & $18.234,29$ & $17.445,47$ & $17.288,34$ \\
Receita UF Total Liq & $20.401,40$ & $21.126,51$ & $21.276,16$ \\
Receita Mun Total Liq & $11.585,82$ & $11.649,52$ & $12.145,50$ \\
\hline \hline
\end{tabular}

Fonte: IPEA, 1985, Tabela I.2, pg. 36, e Tabela A.I.2, pg.52.E Elaboração própria

É importante ressaltar que as estimativas foram feitas somente sobre os impostos que contavam nas tabelas do IPEA, conforme quadro a seguir. Os impostos fora desse quadro não foram somados. É o caso, por exemplo, do IRRF estadual e municipal, do Imposto sobre grandes fortunas, etc. Não havia estimativa para esses casos. Portanto, os valores podem estar subestimados. Dada a sua repartição entre os entes que aparecem 
nas propostas de reforma, sua não contabilização não afeta o argumento principal. Além disso, sobre o ISS, como não havia informação exata disponível sobre a repartição dessa receita entre os entes federados, optou-se por reparti-lo ao meio quando a proposta correspondente determinava que estados e municípios cobrariam o imposto.

\begin{tabular}{lr}
\hline \hline \multicolumn{1}{c}{ Imposto } & Referência: 1984 \\
\hline \hline ICM & $18.332,00$ \\
IR & $15.545,00$ \\
IPI & $4.831,00$ \\
IOF & $2.999,00$ \\
IE & $2.390,00$ \\
Impostos Únicos & $1.464,00$ \\
II & $1.423,00$ \\
ISS & 977,00 \\
IPTU & 678,00 \\
IVVC & 579,00 \\
IPVA & 527,00 \\
ITBI intervivos & 360,00 \\
IVA & $25.781,00$ \\
IPL & 193,00 \\
ISD & 74,00 \\
IFBV & $4.442,00$ \\
IPTR & 41,80 \\
IVA & $25.781,00$ \\
ITBI "causa-mortis" & 74,70 \\
\hline \hline TOTAL & $106.492,50$ \\
\hline \hline
\end{tabular}

Fonte: IPEA, 1985, Tabela I.2, pg. 36, e Tabela A.I.2, pg.52

\begin{tabular}{lccr}
\hline \hline Impostos Únicos & $\begin{array}{c}\text { Valor IPEA (1987) } \\
\text {-TD 108 }\end{array}$ & $\%$ & $\begin{array}{c}\text { Valor } \\
\text { convertido }\end{array}$ \\
\hline \hline IT & 240 & $14 \%$ & 206,77 \\
IUCL & 484,5 & $29 \%$ & 417,41 \\
IUEE & 814,8 & $48 \%$ & 701,98 \\
IUM & 160 & $9 \%$ & 137,84 \\
\hline \hline Total & 1699,3 & $100 \%$ & $1.464,00$ \\
\hline \hline Fonte: IPEA, 1987 texto para discussão 108, Tabela III.1, pg. 38
\end{tabular}

